\title{
Computer-Aided Ligand Discovery for Estrogen Receptor Alpha
}

\author{
Divya Bafna, Fuqiang Ban, Paul S. Rennie, Kriti Singh and Artem Cherkasov *
}

Vancouver Prostate Centre, University of British Columbia, 2660 Oak Street, Vancouver, BC V6H 3Z6, Canada; dbafna@prostatecentre.com (D.B.); fban@prostatecentre.com (F.B.); prennie@prostatecentre.com (P.S.R.); ksingh@prostatecentre.com (K.S.)

* Correspondence: acherkasov@prostatecentre.com

Received: 28 April 2020; Accepted: 9 June 2020; Published: 12 June 2020

\begin{abstract}
Breast cancer (BCa) is one of the most predominantly diagnosed cancers in women. Notably, $70 \%$ of $\mathrm{BCa}$ diagnoses are Estrogen Receptor $\alpha$ positive $(\mathrm{ER} \alpha+)$ making it a critical therapeutic target. With that, the two subtypes of ER, ER $\alpha$ and ER $\beta$, have contrasting effects on $\mathrm{BCa}$ cells. While ER $\alpha$ promotes cancerous activities, ER $\beta$ isoform exhibits inhibitory effects on the same. ER-directed small molecule drug discovery for BCa has provided the FDA approved drugs tamoxifen, toremifene, raloxifene and fulvestrant that all bind to the estrogen binding site of the receptor. These ER-directed inhibitors are non-selective in nature and may eventually induce resistance in BCa cells as well as increase the risk of endometrial cancer development. Thus, there is an urgent need to develop novel drugs with alternative ER $\alpha$ targeting mechanisms that can overcome the limitations of conventional anti-ER $\alpha$ therapies. Several functional sites on $E R \alpha$, such as Activation Function-2 (AF2), DNA binding domain (DBD), and F-domain, have been recently considered as potential targets in the context of drug research and discovery. In this review, we summarize methods of computer-aided drug design (CADD) that have been employed to analyze and explore potential targetable sites on $\mathrm{ER} \alpha$, discuss recent advancement of $\mathrm{ER} \alpha$ inhibitor development, and highlight the potential opportunities and challenges of future ER $\alpha$-directed drug discovery.
\end{abstract}

Keywords: estrogen receptor; breast cancer; computer-aided drug design; virtual screening

\section{Introduction}

\subsection{Breast Cancer and Evolution of Its Treatment}

Breast cancer (BCa) is the most common lethal cancer in women with projected 279,100 new cases and 42,690 deaths in the United States alone this year [1,2]. Although incidence rates have been increasing, the BCa mortality in North America and the European Union (EU) has decreased. This is attributable mostly to early detection, efficient systemic therapies, and the continual focus on developing better drugs for treatment and prevention of BCa [3]. Early-stage BCa, which is contained in the breast or has only spread to the axillary lymph nodes is considered curable in $\sim 70-80 \%$ of patients. Advanced or metastatic disease, however, is currently treatable, but not curable, and the goal of all current therapies is to maintain or improve the quality of life.

On the basis of immunohistochemical expression of prognostic and predictive markers including estrogen receptor (ER), progesterone receptor (PR), human epidermal growth factor receptor 2 (HER2) and the proliferation marker Ki67, clinical practice currently uses a classification of BCa into five subtypes: luminal A-like (ER+, PR+ and HER-), luminal B-like HER2- (ER+, ER and PR expression lower than luminal A-like subtype), luminal B-like HER2+ (ER+, HER2+, ER and PR expression lower than luminal A-like), HER2-enriched non luminal (ER-, PR- and HER2+), and triple negatives (ER-, 
PR- and HER2-) [4]. HER2+ BCa overexpress growth promoting HER2 protein and is treated with the antibody trastuzumab [5-8]. Treatment options for triple negative BCa include cisplatin based chemotherapy [9,10]. High levels of Ki67 relate to higher proliferation rate of the cancer cells and is used as an indicator of grade of the cancer $[7,11,12]$. Altogether, hormone receptor (HR) status, HER2 status and Ki67 levels can be used for streamlined BCa treatment options [4,13-15].

Estrogen and progesterone are the primary regulators of breast tissue growth and differentiation. Both steroid hormones are primarily produced in the ovaries in premenopausal women. However, in postmenopausal women, estrogen is predominantly produced by aromatase enzyme activity on androgens [16]. The critical physiological effects of estrogen on growth, development and maintenance of tissues is exerted via the ER. The ER $\alpha$ subtype has also been implicated in BCa pathogenesis and progression $[17,18]$. More than two-thirds of all BCas are ER $\alpha+$, and precisely targeting ER $\alpha$ and ER $\alpha$ mediated pathways has been the main strategy in $\mathrm{ER} \alpha+\mathrm{BCa}$ treatment and prevention [19]. When BCa cells depend on ER $\alpha$ and or PR for proliferation, they are considered HR+ [20]. FDA approved the selective estrogen receptor modulator (SERM) tamoxifen in 1977, and a selective estrogen receptor degrader (SERD) fulvestrant in 2002 as adjuvant or neoadjuvant hormone therapy (HT) (Figure 1a) with surgery and radiation [21-23]. Tremont et al. [24] reviewed the positive clinical outcome of HT, which includes standard treatment with ER antagonists and/or aromatase inhibitors (AI). Treatment with tamoxifen for five years has been the gold standard especially for premenopausal BCa patients. In postmenopausal women, AIs for five years are superior to tamoxifen, and are considered the new standard of care with conflicting data in the literature $[25,26]$. However, there is no consensus on the ideal sequence of tamoxifen and/or AI and optimal duration of AI therapy.

Combination therapy has been shown to achieve higher efficacy; such as the combination of HT with mTOR inhibitors or CDK4/6 inhibitors are used for tumors with enhanced mTOR signaling and for CDK4/6 sensitive cancer, respectively [27-35]. Notably, Harbeck et al. [4] comprehensively reviewed the prognostication and treatment decision- making of different subtypes of $\mathrm{BCa}$. It is broadly accepted that tamoxifen improves survival in BCa patients, reduces the recurrence rate and prevents $\mathrm{BCa}$ in high risk women. However, about $40 \%$ of the women treated with tamoxifen develop resistance to the drug [36,37].

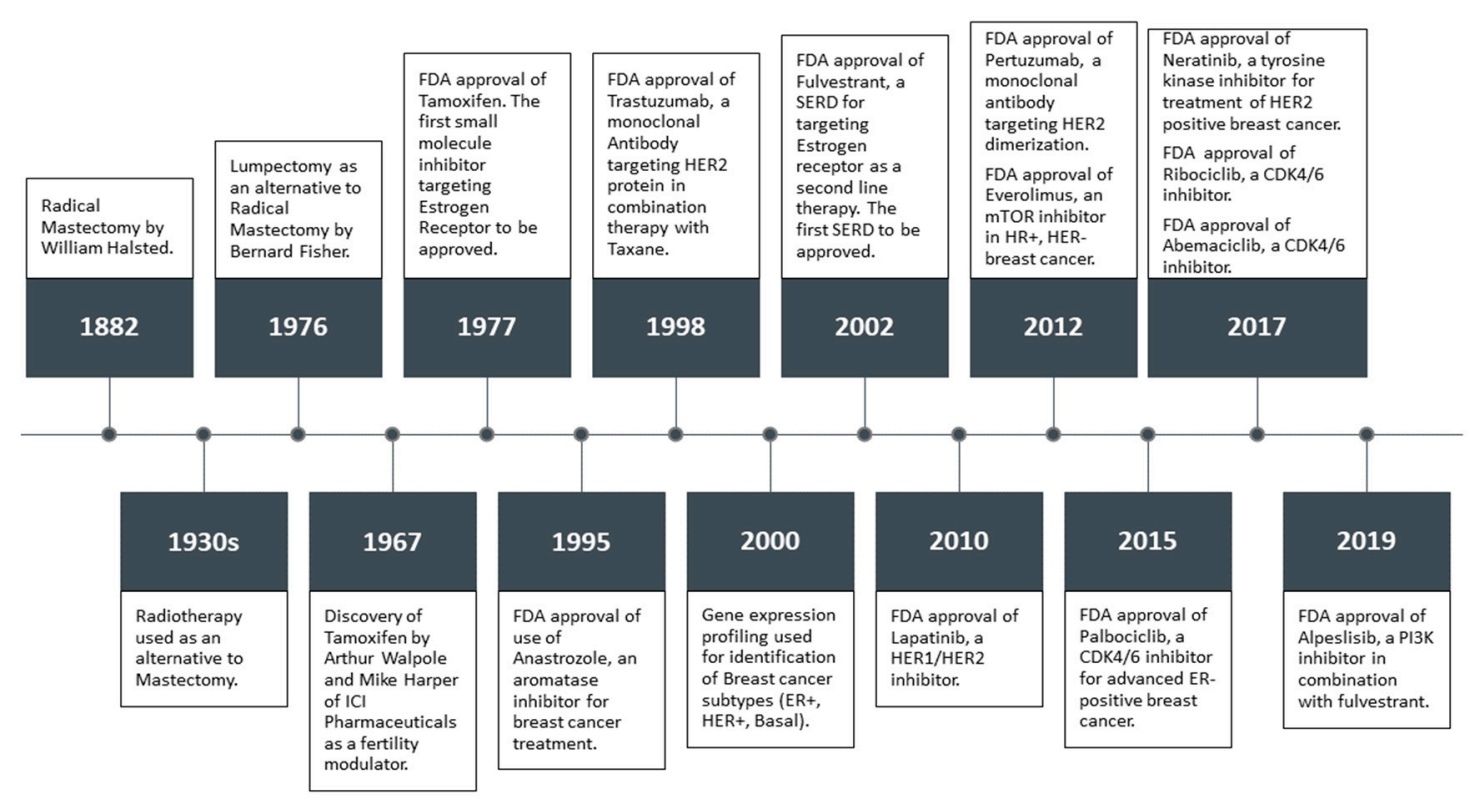

(a)

Figure 1. Cont. 


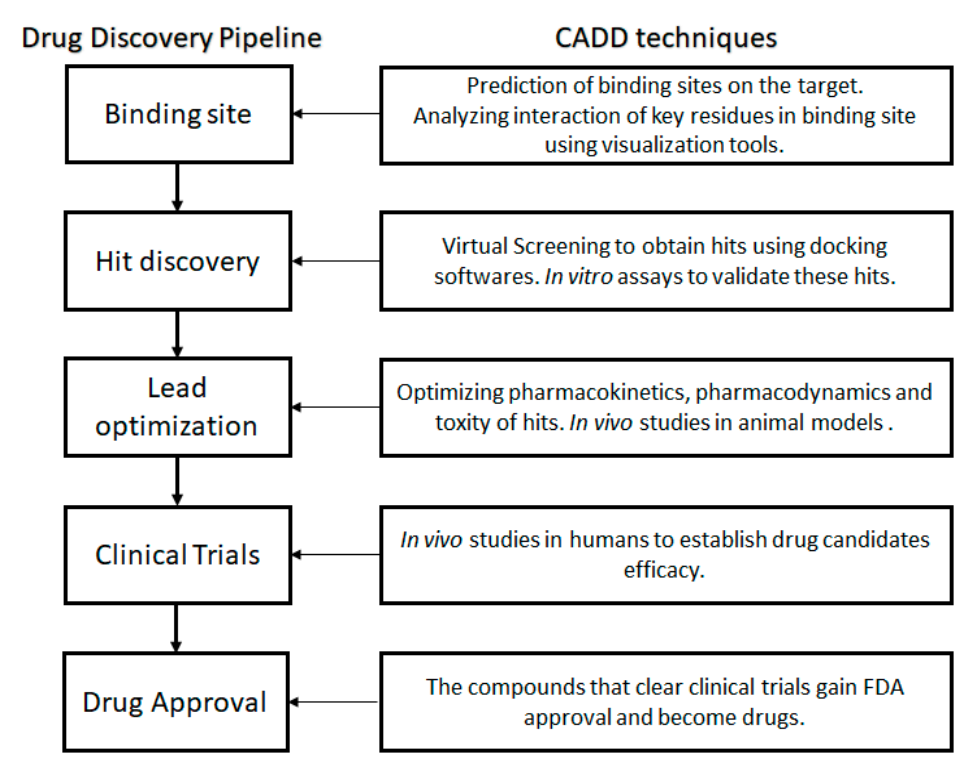

(b)

Figure 1. (a) Evolution of BCa treatment and therapy; and (b) Computer-aided drug design techniques for standard drug discovery pipeline.

\subsection{Computer Aided Drug Design for Estrogen Receptor Inhibitors}

Empirical techniques have been conventionally used in ER drug development; and later experimental-based high throughput screening (HTS) played an important role for the identification of potential hits. Recently, computer-aided drug design (CADD) approaches have contributed to processing cheminformatics and bioinformatics information far more efficiently, thereby accelerating early drug discovery efforts through rigorous molecular docking and free energy perturbation simulations [38]. The ever increasing number of X-ray, NMR and Cryo-EM structures has made the structure based drug design (SBDD) process even more reliable and practical [39]. The general drug development workflow with respective stages is featured in Figure 1b, which can be routinely applied to ER drug discovery.

It should be noted that interactions between the binding site and ligand are complex and difficult to understand without intuitive visualization. In recent years, CADD has advanced dramatically with respect to molecular graphics, docking, scoring functions, molecular dynamic simulation, and various machine learning modeling techniques [40-44]. Different CADD tools can significantly accelerate the progression through different drug stages.

In the absence of experimental structures, homology models of the target protein can be built using protein modeling tools if viable templates with significant sequence identity are available, or with de-novo methods if there are no templates to work with [45,46]. Structural elucidation of intrinsically disordered proteins (IDP) can be difficult using traditional structure solving methods. Thus, FRAGFOLD-IDP approach can be used to find the exact stretches in a protein that are disordered and models can be built using the IDP-LZerD algorithm [47,48]. Molecular Dynamics (MD) simulations can simulate the possible native structures of these stretches for SBDD [49].

Availability of X-ray structures of the protein and ligand is extremely valuable for identification and understanding of the binding site for further SBDD. The MOE SiteFinder tool among other software suites such as, PASS, Q-SiteFinder etc. are user friendly tools to examine the protein-ligand interactions and binding site characteristics [42,50,51]. Docking programs such as Glide, ICM, AutoDock Vina and several others have made it possible to screen ligand molecules (taken from existing databases or prepared de-novo) efficiently with pose prediction and ranked list as outputs [43,52-54]. Although these lists are not precise, they can be used to cut down small molecule libraries to manageable subsets of compounds to be experimentally tested. 
An alternative strategy to develop inhibitors for proteins with no solved structure is to use ligand based drug design (LBDD) approaches. This strategy requires pre-existing activity data of known ligands. Pharmacophore models based on common features of known ligands or the use of Quantitative-Structure activity relationship (SAR) models may be utilized for screening for compounds with desired properties [55,56]. The use of a pseudo-model which involves the building of the binding pocket based on known ligands can also aide drug discovery as it takes into account ligands, their binding poses and solvation scenarios. Thus, the binding site can establish the consistency in binding poses and can be employed using software such as Quasar [57,58]. Lloyd et al. (2004) previously used five widely known antagonists for building de-novo non-steroidal antagonists using SKELGEN without the use of target structure [57,59]. Pharmacophore models and Quantitative-SAR may also facilitate lead optimization on already known hits with ADMET predictors and FEP+ for suggesting better hits $[38,55,56]$.

Continued efforts in building and curating benchmarking datasets along with large scale initiatives such as Environmental protection Agency's (EPA's) endocrine disruptor program have also been immensely useful for evaluating performances of docking software and training predictive machine learning models for major nuclear receptors including ER.

In this review, we present the recent advancements in ER $\alpha$ inhibitor development and highlight the potential opportunities and challenges of future $\mathrm{ER} \alpha$-directed small molecule inhibitor development.

\section{Estrogen Signaling Pathway}

\subsection{ER Gene Expression. Transcriptional, Epigenetic and Post-Transcriptional Control}

The two subtypes of ER, ER $\alpha$ and ER $\beta$, are made up of eight exons each and are encoded by two different genes (Figure 2). The 140-kB-long ESR1 gene located on the long arm of chromosome 6 at q25.1 encodes for $E R \alpha$, a $66.2-k D a$ protein while the ESR2 gene on the long arm of chromosome 14 at q23.2 encodes the 59.2-kDa ER $\beta$ protein. Nine ESR1 gene promoters have been identified so far. These promoters act as a binding site for multiple transcription factors (TFs) that may play a role in tissue and functional specificity. TFs such as AP2a, AP2g, ERBF-1, Foxo3a, FoxM1 and GATA-3 positively regulate ESR1 gene expression while some TFs such as Blimp-1 act as ESR1 expression repressor $[60,61]$. These TFs may be tissue specific and their expressions related to BCa induction. Thus, NK-kB can induce Blimp-1 and Enhancer of Zeste Homolog2 expression which, in turn, may inhibit ESR1 expression. However, it can directly induce ER $\alpha$ transcriptional activity [61]. ESR1 gene amplification has also been implicated in ER $\alpha$ regulation and found frequently in BCa patients [62,63]. Two ESR2 gene promoters have been identified, $O K$ and $0 N$, that bind various TFs such as c-jun, AP2a, AP2g, CREB and Clock/BMAL1 that positively promote ESR2 transcription $[60,61]$.

Notably, CpG island methylation at the ER $\alpha$ promoter has been linked to ER $\alpha$ - BCa, development of aggressiveness, malignancy and resistance to HT [60,64]. Such methylation can directly block the recruitment of TFs to their corresponding binding sites or change the chromatin structure in inhibitory manner. Demethylating agent treatment or inhibition of methylating agents (such as DNA methylation 1) can re-induce ER $\alpha$ expression in $E R \alpha^{-} \mathrm{BCa}$ cells while methyl transferases upregulate $\mathrm{ER} \alpha$ transcription [65]. The $0 \mathrm{~N}$ promoter for ER $\beta$ has been found to be methylated in certain cancer tissues including $\mathrm{BCa}$ while $O K$ promoter was found to be demethylated making $O N$ methylation a target for ER $\beta$ expression manipulation [61]. Acetylation, methylation or phosphorylation of histones can extensively regulate $E R$ gene transcription through chromatin remodeling. Treatment of cells with histone deacetylase inhibitors can induce ER $\alpha$ transcription in $\mathrm{ER} \alpha^{-} \mathrm{BC}$ a cells, rendering the cells sensitive to HT [66].

Post transcriptional regulation of ER $\alpha$ also plays a major role in regulating its expression. AU-rich regions in ER $\alpha$ regulatory regions make it unstable while AUFp45, which protects the mRNA from RNAses, stabilizes the mRNA [61]. Several miRNAs such as miRNA-206, -22, -130a, -17/92 and -145 inhibit ER $\alpha$ expression and in turn miRNA-206, -22, -221 and -222 are inhibited by ER $\alpha$ activity. 
Although not a lot has been uncovered about miRNA activity on ER $\beta$, it was found that miRNA-92 downregulates ER $\beta$ expression [61].
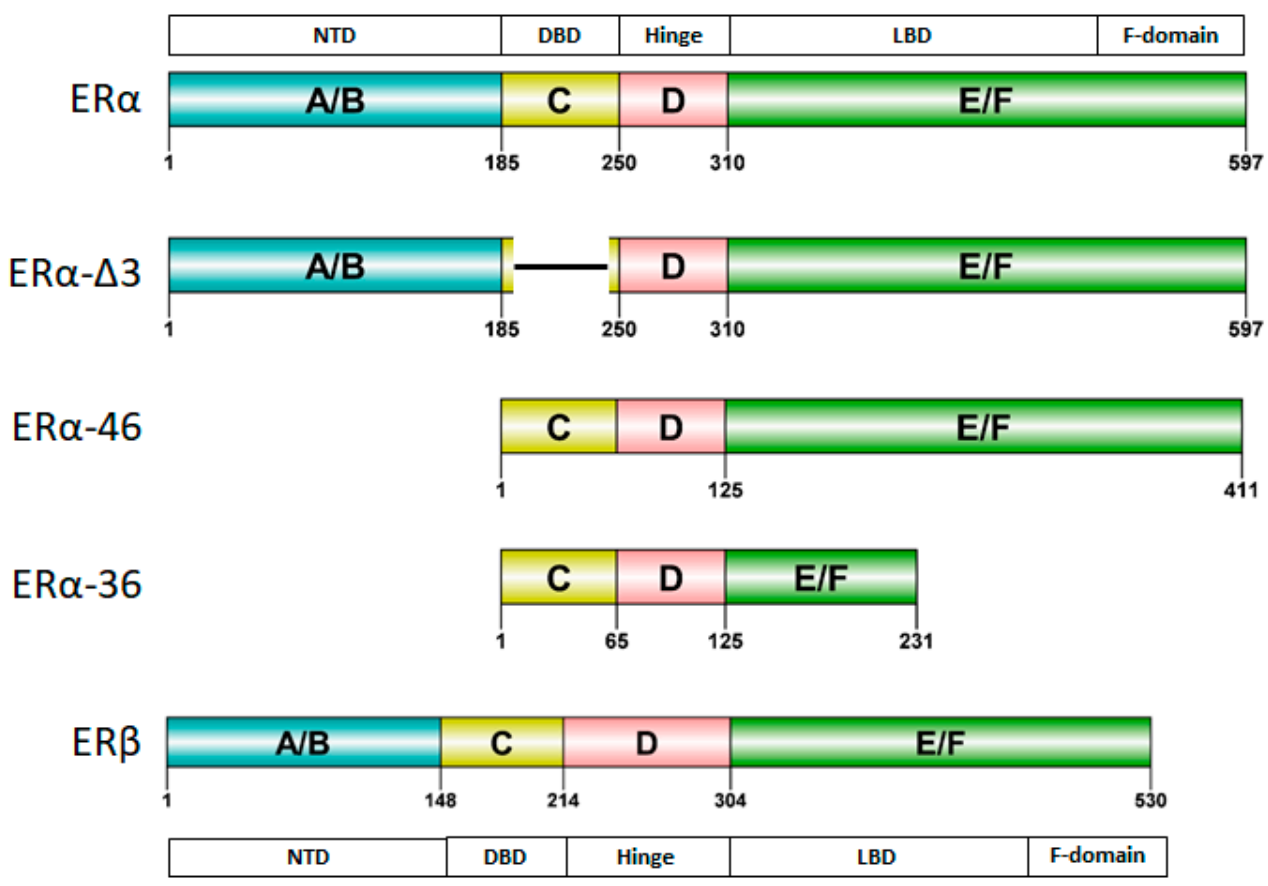

(a)

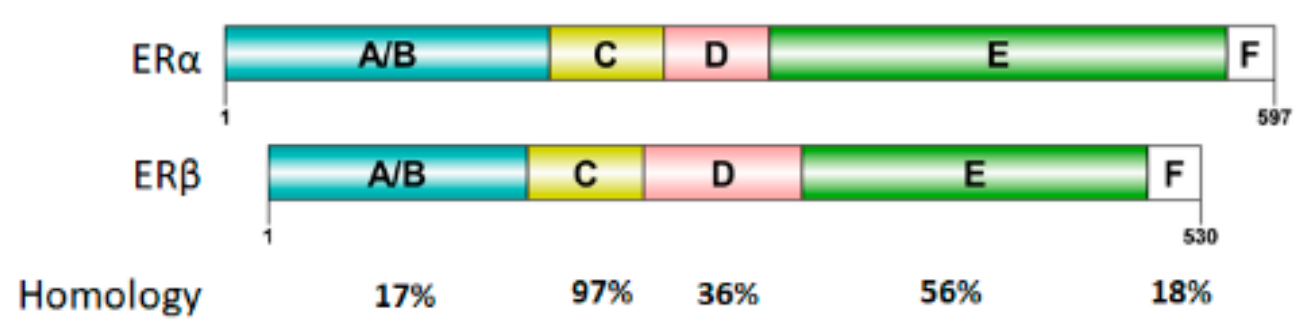

(b)

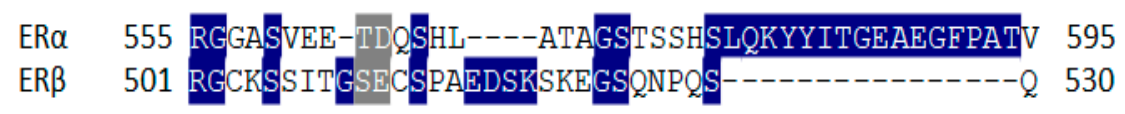

(c)

Figure 2. (a) ER $\alpha$ and $E R \beta$ domain organization; (b) homology of $E R \alpha$ and $E R \beta$ at different domains; and (c) F-domain sequence alignment between ER $\alpha$ and ER $\beta$.

\subsection{ER Protein Organization. Structural Aspects of ER Interaction}

ER is a member of the five-membered steroid hormone receptor (SHR) subfamily which includes Androgen Receptor (AR), Progesterone Receptor (PR), Glucocorticoid Receptor (GR) and Mineralocorticoid Receptor (MR). The two isoforms of ER have the same characteristic domain organization of SHR [67]. Remarkably, ER $\alpha$ and ER $\beta$ can have opposing effects at the promoters of genes involved with proliferation with ER $\alpha$ having a driving effect while ER $\beta$ an inhibitory effect on cell proliferation [61,68-71].

ER, similar to other SHRs, consists of six functional domains labeled A-F: The N-Terminal Domain (NTD) (A/B, encoded by exon 1), the DNA binding domain (DBD) (C, encoded by exons $2-4)$, the hinge region (D) encoded by exon 4 with the ligand binding domain (LBD) (E) and the C-terminal domain (F) 
encoded by exons 5-8 as shown in Figure 2a. Since the homology between ER $\alpha$ and ER $\beta$ differs for the consistent domains, some receptors' regions can therefore be strategically used for selective targeting of $E R \alpha$ (Figure $2 b$ ).

The ER-NTD section houses the important activation function -1 (AF1) which is essential for ER transcriptional activity [72]. Post translational modifications in this area have been shown to result in ligand independent signaling of ER by direct co-regulatory protein recruitment [73-76]. This region is very poorly conserved between all the SHRs with merely $17 \%$ homology between ER $\alpha$ and ER $\beta$. No X-ray structure of ER-NTD has been solved yet as the region is flexible and intrinsically disordered [73]. It has been found to assume a folded, more orderly state when in contact with certain co-regulators [77]. It has been suggested that AF1 of ER $\beta$ may have inhibitory effects on cell proliferation as it has been shown to lack the binding ability to SRC-1, a co-regulatory protein [78].

The highly conserved across all SHRs, DBD region (with a sequence identity of $97 \%$ between $E R \alpha$ and $E R \beta$ ), consists of two Zinc finger motifs recruited for the DNA binding. The first zinc finger encompasses a proximal-box or the P-box which is responsible for recognition of Estrogen Response Element (ERE) on the DNA strand $[79,80]$. The second zinc finger contains the distal-box or the D-box which recognizes the spacing between palindromic ERE and forms the interface for ERE aided ER-DBD dimerization $[79,80]$. There is a stretch of amino acids at the C-terminal of the ER-DBD that is flexible and involved with DNA binding [81]. However, generally, structural details of ER-DBD are somewhat sparse, as only one NMR structure of the DBD monomer and one of ER-DBD dimer in complex with ERE-DNA has been solved so far [82,83].

The hinge region is highly variable amongst SHRs with a low sequence identity (36\%) between $\mathrm{ER} \alpha$ and its subtype, ER $\beta$. This region has a flexible C-terminal and has been implicated in nuclear localization signaling and co-regulatory protein recruitment by synergizing AF1 and Activation Function-2 (AF2) function in ER $\alpha[7,78,84]$. There are four X-ray crystal structures and two NMR structures reported for the hinge region. Five out of the six available structures cover the region near the C-terminus of the hinge domain bordering the ER-LBD [85-87].

The ER $\alpha$-LBD has been extensively studied with approximately $265 \mathrm{X}$-ray structures, some of which include the C-terminal segment of the hinge region. There are $36 \mathrm{X}$-ray structures of ER $\beta$-LBD reported so far. Although this region shows only $57 \%$ identity with ER-LBD their overall structures and mechanism of action are similar. The ER-LBD houses the estrogen binding site (EBS), AF-2 site and the ER-LBD dimerization interface. It consists of $12 \alpha$-helices (H1-H12) forming three layers with H4-6, H8 and H9 sandwiched between H1 and H3 on one side and H7, H10 and H11 on the other (Figure 5) [88]. This fold forms a highly hydrophobic cavity corresponding to the EBS. The use of MOE package enabled visualization of critical protein-ligand interaction presented in Figure 3, where in native conditions, E2 binds to the hydrophobic cavity formed between the sandwiched helices of ER $\alpha$ comprising of the residues Met343, Leu346, Ala350, Glu353, Leu384, Leu387, Met388, Leu391, Arg394, Phe404, Met421, Ile242, Leu428, Gly521, His524 and Leu525 [42,89]. The hydroxyl group on the A ring/phenolic ring of E2 forms H-bonds interaction with Glu353 and Arg394 while the hydroxyl group on the other end of the compound interacts with the Sulfur in Met343 [89].

Binding of estrogens to the EBS causes a conformational change in the receptor due to the movement of $\mathrm{H} 12$ which, in turn, opens up the AF-2 site for coactivator recruitment $[17,90]$. AF1 and AF2 act in synergy for full transcriptional activity of ER [72]. Furthermore, H8-H11 motifs play a role in LDB dimerization with most important interactions corresponding to H10 and H11 [91,92]. These helices are also implicated in hormone binding interactions. It has also been demonstrated that ER-LBD can form both homo and heterodimers [93]. H11 is also important because it contains the nuclear localization signal [94]. The amplification of signals in the ER pathway leads to uncontrollable cell proliferation and growth resulting in tumor formation [95]. 


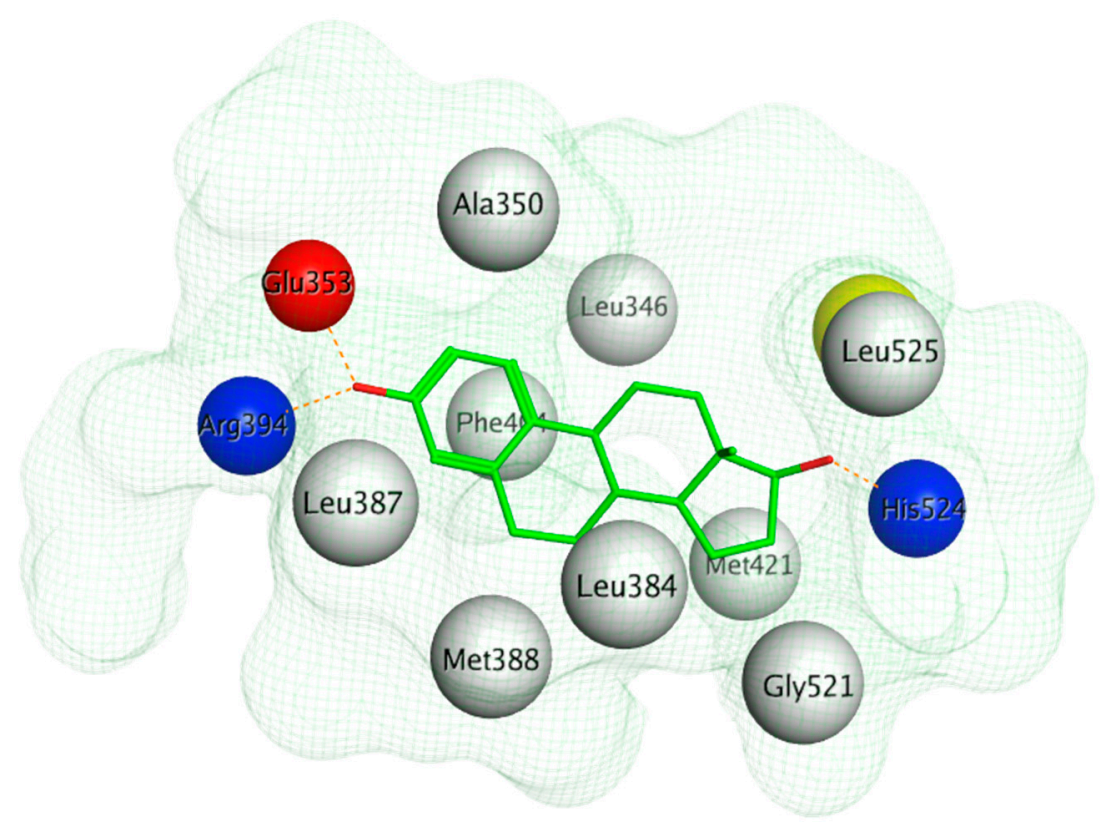

Figure 3. E2 (Green) bound to wild-type ER $\alpha$ at the EBS (pdb: 1QKU). The hydrogen bonds are depicted using dashed lines (orange). E2 forms two hydrogen bonds on one side with Arg394 and Glu353 and forms one on the other side with His524.

The F-domain can be promising for introducing the desired selectivity in ER inhibition as it is highly variable amongst all the SHRs and is poorly conserved in the two subtypes of ER (18\% identity as shown in Figure 2c). It has been implicated in ligand-based regulation of ER mediated transcription $[96,97]$. The F-domain was also found to be involved in inhibition of LBD dimerization, tamoxifen responsiveness and antiestrogen mediated transactivation of ER $\alpha[96,98]$. Thus far, eight structures of C-terminal segments of F-domain in complex with 14-3-3 protein have been experimentally resolved $[99,100]$.

Wild type ER $\alpha$ has three known naturally occurring variants: ER $\alpha-46, \mathrm{ER} \alpha-36$ and ER $\alpha$-delta3 (Figure 2a). ER $\alpha-46$ has a truncated AF1 that is involved in hormone dependent growth of cancer cells and its induction in tamoxifen resistant cells restores sensitivity [101-103]. Another ER $\alpha$ variant, ER $\alpha-36$, with a spliced AF1 and a portion of LBD, regulates hormone dependent and independent signal transduction in cancer cells and increases the tumorigenesis and invasiveness [104-106]. ER $\alpha-36$ has been reported to induce sensitivity to ER $\alpha$ antagonists [107]. ER $\alpha$-delta3 variant of ER $\alpha$ with a truncated DBD, reduces metastasis and proliferation in BCa cells $[108,109]$.

Point mutations in ESR1, have been reported play a part in HT resistance. Thus, frequent point mutations have been found in $\mathrm{HT}$ relapsed patients with metastatic $\mathrm{BCa}$, but not in untreated patients. These mutated cells may evade the initial round of HT with ERS1 mutation found in $22 \%$ of the metastatic BCa patients [110,111]. Residues 534-538 have been the hotspot of mutations with additional mutations discovered on Ser463 and Glu380 [111]. Moreover, mutations such as L536N, Y537S, Y537N and D538G may activate ER $\alpha$ in the absence of an agonist [112-115]. Current clinical dosage of antagonists are ineffective on mutant forms of ER $\alpha$. Higher dosages of the same have been shown to be effective on some mutants [109].

\subsection{Estrogens}

Estrogens are female sex hormones majorly produced in the ovaries and in the placenta (during pregnancy). Estrogen steroids play a paramount role in the development, regulation and maintenance of female reproductive system [116,117]; they are essential in cognitive health, metabolism, bone formation, mobilization of neutrophils and cardiovascular activity among others [116,118-123]. 
Primarily, androgen synthesis from cholesterol occurs in the thecal cells of ovaries and aromatization of these androgens in granulosa cells leads to the production of estrogens but they can also be produced by other non-gonadal sites such as brain, adipose tissue, bones, liver, adrenal gland, skin and blood vessels [116,124]. Estrogen formation is tightly regulated by the hypothalamic pituitary ovarian axis $[125,126]$. Gonadotropin-releasing hormone stimulates the anterior pituitary gland to release two hormones: luteinizing hormone, which initiates the synthesis of testosterone, and follicle-stimulating hormone, which regulates the expression of aromatase cytochrome P450 [125]. Cytochrome P450 aromatizes androgens to produce estrogens. Follicle-stimulating hormone is the rate limiting step in estrogen production [127].

There are four naturally occurring types of estrogen: estrone (E1), 17 $\beta$-estradiol (E2), estriol (E3) and esterol (E4). E1 and E2 are produced mainly by the ovaries, E3 is produced by the placenta and E4 is produced primarily in the fetal liver during pregnancy $[125,128]$. E2 is the predominantly produced estrogen and the most potent of them all, being 100-fold more potent than E3 and 10 times more potent than E1 [129].

\subsection{ER Transcription Mechanism}

The classic ER transcription mechanism is shown in Figure 4 (left). The binding of E2 at the EBS site featured in Figure 4 (right) triggers the signaling pathway by activating cytoplasmic ER with a conformational change that subsequently triggers receptor dimerization, nuclear translocation and exposes the ER-AF2 site for subsequent co-activator binding [130-134]. Once in the nucleus, the DBD region of the ER recognizes and interacts with the ERE, a consensus 5'-GGTCAnnnTGACC-3' palindromic sequence, for nuclear transcription as a DBD/DBD dimer and then the ER complexes with co-activators such as p160 family of proteins that includes Steroid receptor Coactivator (SRC-1), GRIP-1 and Alb1 (Figure 4) [135]. In addition, the F-domain, when not in contact with repressor proteins such as 14-3-3, interacts with AF1 for full transcriptional activity of ER [99]. It is of particular importance that all these consequent ER activation steps could, in principle, provide significant opportunities for modulating ER functioning with small molecules. 


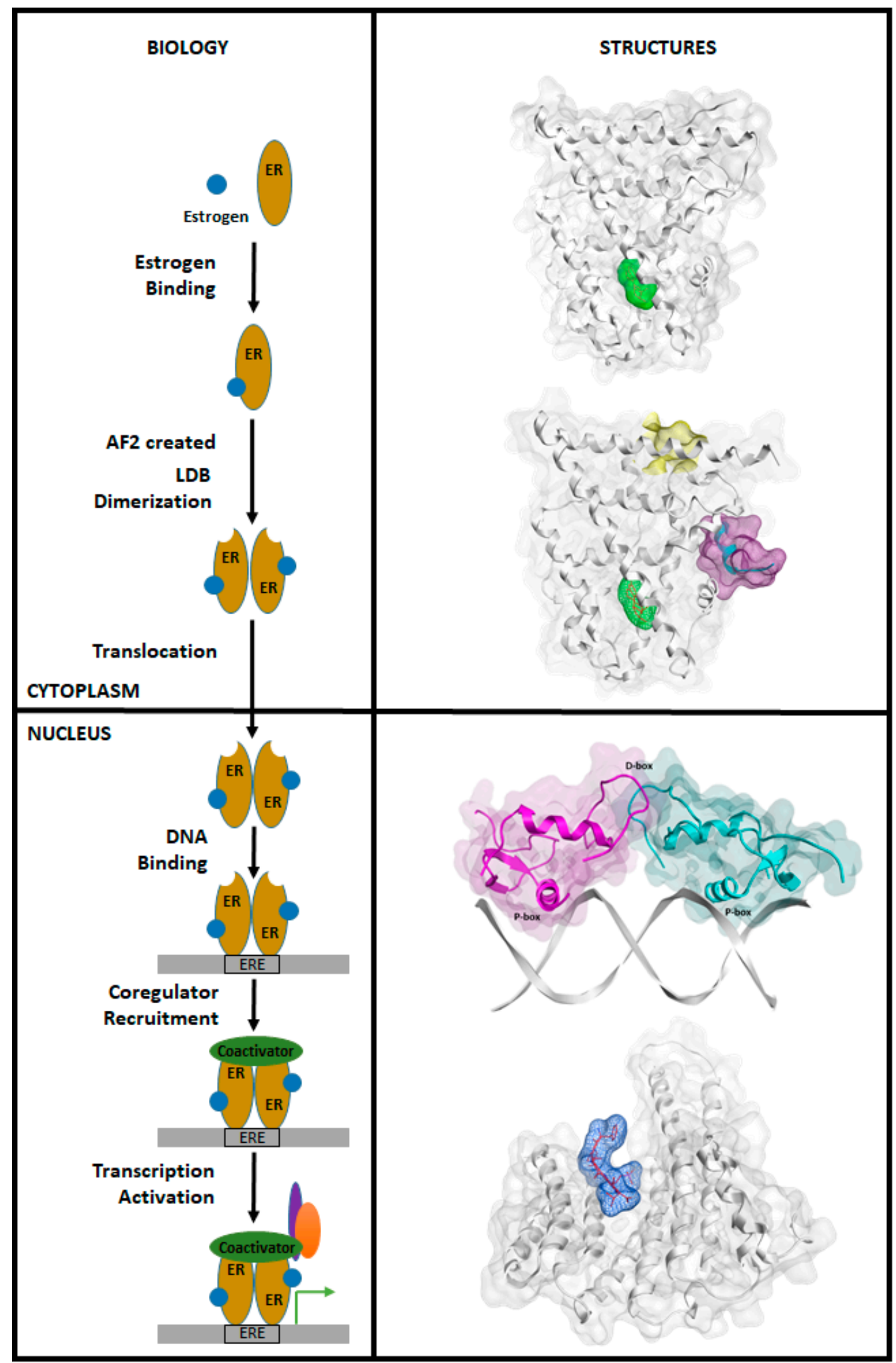

Figure 4. The biology of classic ER transcriptional mechanism (left) with the corresponding structures (right): the first structure depicts E2 (green) bound to the ER-LBD; the second structure depicts an E2 (green) activated ER with an coactivator docked to the created AF-2 site (purple) along with the potential dynamic BF3 site (yellow); the third structure shows a translocated DBD/DBD ER dimer bound to DNA; and the fourth structure shows the F-domain bound to an AF-1 mediated transcription repressor protein, 14-3-3 (white). 


\section{Small Molecule Inhibitors}

\subsection{Targeting EBS}

\subsubsection{Selective Estrogen Receptor Modulators (SERMs)}

SERMs can exert agonistic or antagonistic effects on ER depending on the tissue type, receptor's subtype and the ERE promoter sequences. As antagonists, SERMs induce a conformational change in ER to its inactive state [136-138]. The most notable SERMS are collected into Table 1, and their brief historical background is presented below.

In the 1960s, in pursuit of developing a potential non-steroidal anti-estrogen contraceptive using a triphenylethylene core, Dr. A. L. Walpole at ICI Pharmaceuticals (Astra Zeneca) discovered a compound ICI146,474, later known as tamoxifen. This first FDA-approved SERM has become the gold standard drug for $\mathrm{ER} \alpha+\mathrm{BC}$ a treatment and prevention in both pre- and post-menopausal women, and since 1978 it has paved the way for further generations of SERMs [139-141]. Five-year adjuvant therapy with tamoxifen results in a 75\% decrease in risk of recurrence between 10 and 14 years and $80 \%$ with a 10-year administration in ER $\alpha+$ patients [142]. In treatment of pre-menopausal women with advanced $\mathrm{BCa}$, the response rates ranged from $20 \%$ to $45 \%$, while for $\mathrm{ER} \alpha+$ and $\mathrm{ER} \alpha+/ \mathrm{PR}+$ cancers response rates were $50 \%$ and $60-70 \%$, respectively, for post-menopausal women with advanced BCa [143]. However, long-term administration of tamoxifen results in an acquired drug resistance in the initially responsive tumor [144]. Resistance may be caused by cells expressing certain regulators interacting with tamoxifen-bound ER [36,37], crosstalk between HER2 and ER $\alpha$ or ligand independent signaling through other pathways of PI3K/mTOR or NFkB [145-147], differential microRNA expression [145,148-151] or increase in E-cadherin methylation [152], among other mechanisms reviewed elsewhere [153-155]. In addition, tamoxifen has an agonistic effect on endometrial cells leading to an increased risk of developing uterine cancer. Moreover, it causes undesired pure antagonist effects on ER $\beta$ [156].

Comparison of E2 and 4-hydroxy-tamoxifen (OHT), a metabolite of tamoxifen, bound to ER $\alpha$ illustrates the structural transformation that leads to the antagonist action of OHT (Figure 5).

The desired therapeutic effect of OHT is exerted by a structurally deactivated ER-LBD. When E2 binds to the highly hydrophobic EBS, the ER is activated through coactivator binding (yellow) to the AF2 site dynamically created due to the H12 orientation (cyan) represented in Figure 5a. However, upon OHT binding, the H12 (cyan) is repositioned (schematically shown in Figure 5b) such that it blocks the AF2 site required for coactivator binding. The consequence of the conformational change of H12 in ER-LBD results in the antagonist action of OHT as can clearly be seen in Figure 5 visualized using MOE [42,157]. In 2016, Ho Leung Ng ran a 240-ns MD simulation on both E2 bound ER $\alpha$ (pdb entry 1ERE) and OHT bound ER $\alpha$ (pdb entry 3ERT) to find that not only did the OHT/antagonist bound $\mathrm{ER} \alpha$ display disorder in both $\mathrm{H} 12$ edges and undergo fluctuations but it also resulted in a stabilized antagonistic conformation of H12 [158]. MD simulation has also been previously used to study the differences between ER $\alpha$ and ER $\beta$ for ligand selectivity [159].

Following the success of tamoxifen in BCa suppression, new compounds with either the same or different cores were developed. Thus, to further optimize tamoxifen, its close derivatives toremifene, droloxifene and idoxifene were synthesized, all carrying the core triphenylethylene structure (Figure 6) [160,161]. 
Table 1. List of notable Selective estrogen receptor modulators.

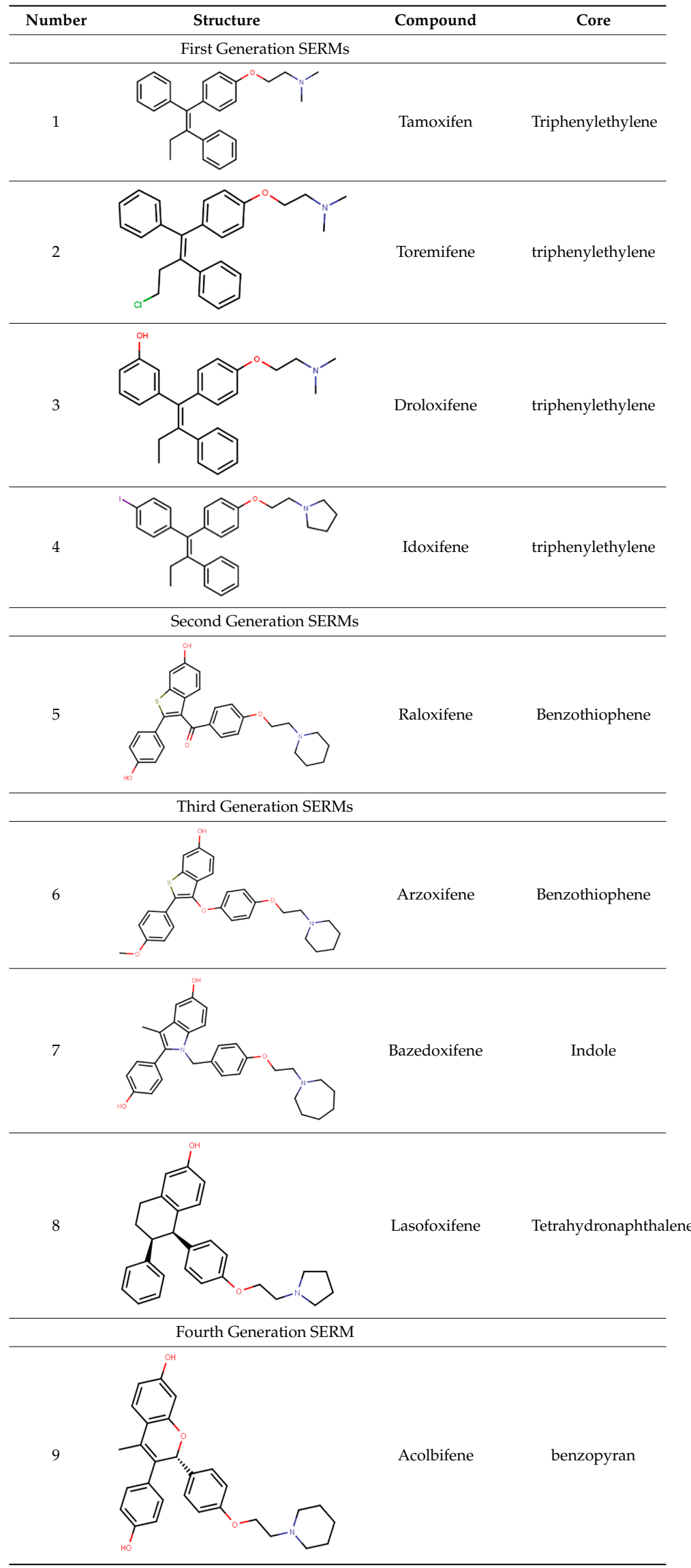




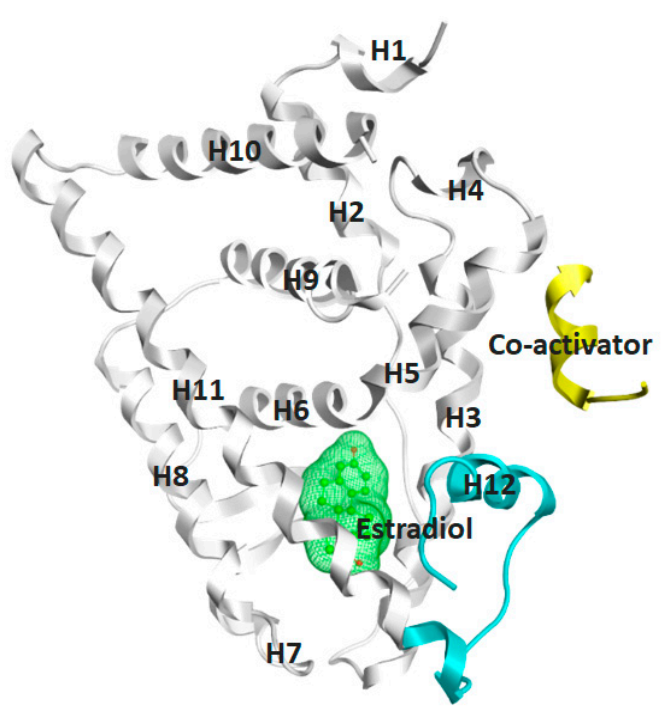

(a)

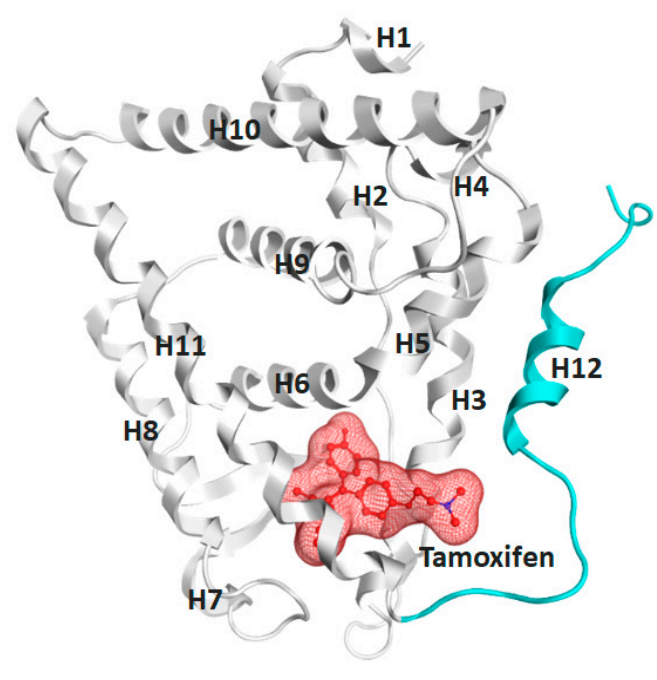

(b)

Figure 5. (a) E2 (green) bound to ER $\alpha$ (white) and the coactivator peptide (yellow) (pdb: 3UUD) with the helix numbers from 1 to 12 specified. The binding of E2 moves the H12 to its active conformation, creating the AF2 site that binds to Co-activator proteins. (b) OHT (red) bound ER $\alpha$ (white) (pdb: 3ERT). Binding of OHT moves the H12 to an antagonistic conformation, blocking the AF2 site.

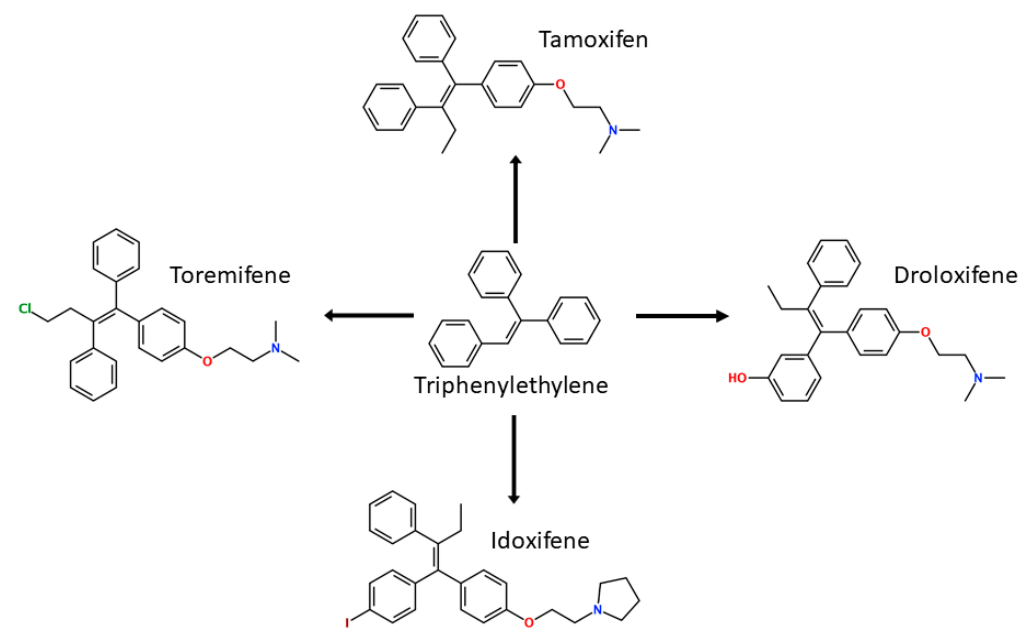

Figure 6. Common triphenylethylene core used to build tamoxifen, toremifene, droloxifene and idoxifene.

Tamoxifen was the only approved anti-estrogen for BCa treatment until 1997, when toremifene also passed FDA approval [162,163]. It demonstrated similar tolerability and safety as tamoxifen and its long-term administration also elevated the risk of endometrial cancer development [164]. On the other hand, while toremifene was found to be three times less potent than tamoxifen, it was characterized as less carcinogenic compared to tamoxifen. More importantly, toremifene is more selective towards ER $\alpha$ than ER $\beta$, while tamoxifen is nonselective $[165,166]$. Of note, both droloxifene and idoxifene were never marketed, as they demonstrated lesser efficacy and response rate compared to tamoxifen, and were terminated in the respective Phase III trials $[167,168]$. All three of these molecules were found to be cross-resistant towards tamoxifen in the corresponding resistant cells [167-169].

To eliminate the risk of endometrial cancer development and cross-resistance to tamoxifen in first generation SERMs, further pharmaceutical development led to second and third generation SERMs. 
Thus, raloxifene, a benzothiophene-based short-acting drug, is the only established second generation SERM [170]. Initially, Black and Goode (1980) and Jones et al. (1983) noted the effects of raloxifene on BCa cell lines and mammary tumors in rats, respectively [171,172]. It failed initially in a Phase II trial in metastatic BCa for lacking activity [173], but was later approved in 2007 for BCa prevention in postmenopausal women with high risk. The $\mathrm{IC}_{50}$ values of raloxifene in proliferation inhibition of MCF-7 cells were found to be $0.4 \pm 0.3 \mathrm{nM}$ [174]. In addition, it was found to reduce uterine cancer development by almost half compared to tamoxifen, though it showed lower efficacy than tamoxifen $[138,166]$. However, results from a randomized trial concluded that raloxifene increases the risk of thromboembolism and strokes in post-menopausal women $[175,176]$. Moreover, due to its poor solubility and metabolic instability, it has poor bioavailability (2\%) [177].

To address the shortcomings of these two drugs, the third generation of SERMs including arzoxifene and others with improved bioavailability were developed (Table 1). Palkowitz et al., in 1997, substituted the carbonyl group in raloxifene with an oxygen atom to make arzoxifene using SAR modeling [174]. $\mathrm{IC}_{50}$ of arzoxifene in inhibiting MCF-7 cell proliferation is $0.05 \pm 0.02 \mathrm{nM}$, which is significantly more potent than raloxifene [174]. Arzoxifene displayed cross-resistance to tamoxifen in MCF-7 cells but not in T47D cells [178]. It has lower risk for development of endometrial cancer than tamoxifen, but also has shorter time to treatment failure than tamoxifen and it produces half the median progression free survival of tamoxifen, which resulted in the failure of its Phase III trial $[179,180]$.

Other third generation SERMs, bazedoxifene and lasofoxifene (both developed by Pfizer), have been approved for the treatment of osteoporosis. Bazedoxifene is a highly potent indole-based SERM/SERD hybrid compound, which was found to have an $\mathrm{IC}_{50}$ of $0.19 \mathrm{nM}$ in inhibiting E2 mediated proliferation of MCF-7 cells $[181,182]$. Bazedoxifene displays SERD like activity but acts predominantly as a SERM in BCa tissue [181,183]. It binds to ER $\alpha$ with an $\mathrm{IC}_{50}$ of $26 \mathrm{nM}$ and has shown activity on tamoxifen-resistant cells $[181,183]$. It displays a slightly higher affinity towards ER $\alpha$ than ER $\beta$ with reported $\mathrm{IC}_{50 \mathrm{~s}}$ of 14 and $40 \mathrm{nM}$, respectively, as measured using a radioligand binding assay [165,184]. In 2009, the drug was approved as a monotherapeutic agent for the prevention and treatment of osteoporosis in post-menopausal women in the EU. Since then, the drug has also been FDA-approved as a combination therapy with conjugated estrogens for prevention of osteoporosis in postmenopausal women [185]. Phase $\mathrm{Ib} / \mathrm{II}$ study of bazedoxifene administered in combination with palbociclib (a CDK4/6 inhibitor) in pre-treated HR+ BCa concluded that the combination is tolerable and displayed notable activity [186]. The drug is currently in a Phase II trial for in-situ ductal carcinoma patients for determining its effect on proliferation markers of BCa [187].

Lasofoxifene is a tetrahydronaphthalene based SERM marketed under the name of Fablyn. It is an oral drug that has been shown to decrease ER $\alpha+$ BCa risk with higher inhibitory activity than tamoxifen $[165,188]$. Lasofoxifene has an $\mathrm{IC}_{50}$ of $1.08 \mathrm{nM}$ towards ER $\alpha$ and $4.41 \mathrm{nM}$ for ER $\beta$. Lasofoxifene treatment for five years leads to endometrial changes but does not pose uterine cancer development risk [189]. There is currently an ongoing Phase II trial to study the activity of lasofoxifene against fulvestrant in ESR1 mutated advanced/metastatic ER $\alpha+/$ HER- BCa [190].

Using MOE visualizing package, we can see that raloxifene and lasofoxifene bind to the EBS in the same manner as OHT (Figure 7) [42,92,191,192]. The structure analysis demonstrates that the A-ring hydroxyl group of all ligands forms H-bonds with the Glu353 and Arg394. The D-ring phenolic hydroxyl group of raloxifene interacts with a rotated His524 sidechain which is flexible in nature [193]. The OHT side chain is stabilized by a salt bridge formation between the dimethylamino group on the side chain and Asp351 [191]. The piperazine ring nitrogen in the side chain of raloxifene and pyrrolodine nitrogen in the side chain of lasofoxifene interact with Asp351 [92,192]. As shown in Figure 5, raloxifene and lasofoxifene similar to OHT displace the H12 (cyan in Figure 5) due to steric clashes of their bulky side chains with EBS residues leading to inactive conformation of ER $[92,191,192,194]$. 


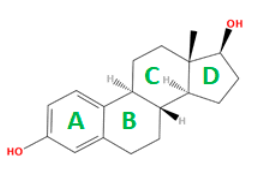

Estradiol

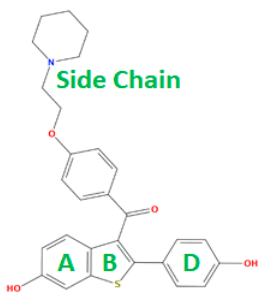

Raloxifene

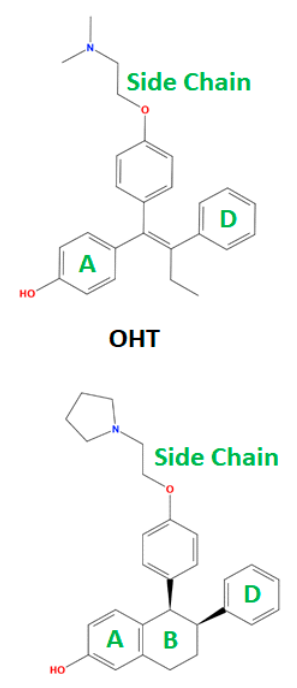

Lasofoxifene

(a)

Figure 7. (a) Ring nomenclature and side chain of OHT, raloxifene and lasofoxifene in accordance with conventional E2 nomenclature; and (b) OHT (green), raloxifene (cyan) and lasofoxifene (pink) complex with the EBS (pdb: 3ERT, 1ERR and 2OUZ) with dashed lines (Orange) depicting hydrogen bonds.

Many small molecules have recently been claimed to be fourth generation SERMs due to their improved activity, but only acolbifene, a benzopyran derivative discovered by Labrie et al. in 1999, is well established [195]. EM-800 is a well-studied precursor of acolbifene which was found to be safe and tolerable $[196,197]$. It is orally active but lacks agonistic activity in the endometrium, thereby reducing the chances of developing uterine cancer [198-200]. The drug was found to have partial cross-resistance with tamoxifen [198]. Acolbifene is currently in Phase II trial for its activity in premenopausal women who are at high risk for developing BCa [199].

Readily available structures of ER-LBD along with molecular docking programs has made it easier to study the docked poses of empirically bound ligands. A few authors have used docking to study the poses and conformations of these compounds and have found them to be potent in vivo and/or in vitro experiments or to predict their relative activity. In 2019, Sharma and colleagues used in silico docking to support the activity of their designed and synthesized tetrahydro-b-carboline-isatin conjugates with both tetrahydro-b-carboline and istatin C-1 and C-5 stereomers [201]. The most promising hit displayed an $\mathrm{IC}_{50}$ of $37.42 \mu \mathrm{M}$ against MCF-7 cells as opposed to $50 \mu \mathrm{M}$ for tamoxifen and had minimal effects on ER $\alpha$ - MDA-MB-231 cells thus confirming that their actions are ER $\alpha$ mediated [201]. The authors used Chem3D Ultra to draw their ligands and Avogadro1.2.0 tool to optimize them for docking to the UCSF Chimera prepared protein (pdb entry 3ERT) using AutoDock Vina [54,201-203]. The molecule had similar hydrophobic interactions to tamoxifen and scored fairly high in terms of docking [201]. All the conjugates were predicted to bind better than tamoxifen, but this was not the case experimentally as docking scores are not always representative of reality [201]. Similarly, Katzenellenbogen and collaborators used docking to study the poses and contribution of side chains in antagonistic activity of their proposed compounds on mutant forms of ER $\alpha$ [204]; Singla and colleagues used docking to study the poses of experimentally active novel indole-based antagonists [205]; and Lou et al. used AutoDock to model their best designed hits $[206,207]$.

SBDD using docking programs and pharmacophore models have accelerated the drug discovery process. Various groups over the years have employed these CADD tools for finding novel inhibitors from available databases and experimentally testing the best hits to validate their findings. Virtual Screening (VS) studies have been conducted for the discovery of ligands for the ER $\alpha$-EBS pocket [208-215] and for all subtypes of ER [209,210,216-222]. 
In 2015, Istyastono and group used PLANTS1.2 software for repurposing of a popular cyclooxygenase-2 inhibitor, celecoxib (Table 2) for ER $\alpha$ (with and without conserved water molecules) $[223,224]$. After docking, they used these results to find their protein-ligand interaction fingerprints (PLIF) [223]. From the three docking runs, best docking poses and poses with best Tanimoto coefficient (Tc) with respect to the reference OHT fingerprints Tc were selected, and then this method was repeated 1000 times for statistically validating the Tc values [223]. Using the Wilcoxon test, the authors were able to determine that the values were equal or better than the set standard threshold of 0.720, thus confirming that celecoxib may be repurposed as potential ER $\alpha$ ligand [223]. Celecoxib from the marketed drug Celebrex in MCF-7 cell cytotoxicity assay displayed an IC $_{50}$ value of $94.06 \pm 14.03 \mu \mathrm{M}$ compared to that of $40.78 \pm 0.48 \mu \mathrm{M}$ for the reference, tamoxifen giving comparable results [223].

Table 2. ER ligands validated with CADD.

\begin{tabular}{|c|c|c|}
\hline Compound & Structure & Activity \\
\hline Celecoxib & & $\mathrm{IC}_{50}=94.06 \pm 14.03 \mu \mathrm{M}(\mathrm{MCF}-7$ cell cytotoxicity assay $)$ \\
\hline S4 & & $0.25 \mu \mathrm{M}$ (FP assay) \\
\hline YMA-005 & & $\mathrm{IC}_{50}=1.76 \mathrm{nM}(\mathrm{ER} \alpha$ ELISA binding assays $)$ \\
\hline YMA-006 & & $\mathrm{IC}_{50}=3.31 \mathrm{Nm}(\mathrm{ER} \alpha$ ELISA binding assays $)$ \\
\hline
\end{tabular}

19

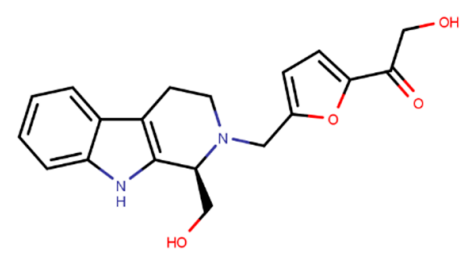

Only active at high Concentrations

In a similar study, Niinivehmas et al. (2016) used two separate databases-one from ChEMBL and the other from directory of useful decoys (DUD), prepared using LigPrep2.5 and protonated at pH 7.4 using Confgen in force field MMFF94 [225]. Pharmacophore model was built using PHASE3.3 and 
a 3D-QSAR model was constructed $[225,226]$. Pdb entry 3ERT (OHT bound to ER $\alpha$ ) was prepared using Maestro9.2 with preservation of water in the binding site and then minimized in force field OPLS-2005 [225,227]. Both the datasets were then docked to the prepared structure using Glide5.7 SP and XP as well as PLANTS [43,224]. Negative image based models were created with receptor flexibility taken into account by running MD simulations and then screened across the two databases using SHAEP $[225,228]$. The authors then used SPECS database for finding hits based on the above models with pharmacophore posing difficulties as five features posed to be too specific and four features were unable to differentiate between the inactives and actives yielding five hits with "Compound S4" (Table 2) showing an $\mathrm{IC}_{50}$ value of $0.25 \mu \mathrm{M}$ in Fluorescence Polarization (FP) assay [225]. A database of coumarin-based compounds was also screened using the same pipeline and the top five hits were synthesized and tested in vitro for $\mathrm{IC}_{50}$ values of $0.31-3.1 \mu \mathrm{M}$ (FP assay) [225].

Pang et al., in 2018, used CADD for the development of antagonists of ER $\alpha$ using the antagonists form BindingDB database and DUD enhanced (DUD-E) decoys, which were further processed with MOE, also adding a marker of 1 for antagonists and -1 for decoys [42,229]. The authors used 2D and 3D descriptors generated using MOE and Discovery Studio selected on the basis of Pearson's correlation as features for their Naïve Bayesian and Recursive Partitioning Classifier models for fivefold cross validation runs with the best models obtained using MOE 2D descriptors and molecular fingerprints for both model type $[42,229,230]$. Receptor structure from pdb entry 3ERT was used for molecular docking using LibDock and CDOCKER to further analyze results by the best machine learning models [229-232]. The best machine learning models along with molecular docking were then used to screen through their in-house database of natural compounds [229]. FP assay was used to analyze their in silico hits with eight compounds, including genistein, displaying antagonism towards $\mathrm{ER} \alpha$ within the range of 29.38-977 nM [229].

In same year, Wang et al. assessed cyclopropyl derivatives to develop ER $\alpha$ selective novel SERMs with the aid of docking using Discovery Studio 2.5 against both ER $\alpha$ (pdb entry 1A52) and ER $\beta$ (pdb entry 3OLS) [230,233]. The authors were able to discover five compounds with ER $\alpha$ activity ( $\mathrm{IC}_{50}$ ranging between 1.79-6.27 $\mu \mathrm{M}$ ) but with non-detectable binding to ER $\beta$ using FP assays [233]. Luciferase reporter Assay confirmed that all the molecules were antagonistic towards ER $\alpha$ and were antiproferative in MCF-7 cells [233]. In a similar study, Jin and group used AutoDock Vina4.0 to dock Benzofuran derivatives in an attempt to identify novel SERMs using the pdb entry 3ERT as the target protein for docking [54,234]. The hits were tested in MCF-7 cells, MDA-MB-231 cells and HEK-293 cells giving $\mathrm{IC}_{50}$ value comparable to that of tamoxifen and raloxifene [234].

Hendy et al. created an indole base library and docked the same to protein obtained from pdb entry 1ERE with conformation generated using Omega and docked using FRED [213,235,236]. The compounds had similar interactions as that of E2 along with indole ring interactions with Thr347 [213]. YMA-005 and YMA-006 (Table 2) showed IC $_{50}$ values of 1.76 and $3.31 \mathrm{nM}$, respectively, in ER $\alpha$ ELISA binding assays [213]. The compounds also inhibited proliferation in MCF-7 and T-47D cell lines with $\mathrm{IC}_{50}$ values of around $28.23-32.96 \mu \mathrm{M}$, which is lower than that of $34.42 \pm 0.83$ and $42.40 \pm 0.78 \mu \mathrm{M}$ observed in the case of tamoxifen treatment [213]. Both compounds could reduce tumor size combined with reduction in immunohistochemical expression of $E R \alpha$ [213]. The compounds also caused ER $\alpha$ degradation along with an increase in cell necrosis [213].

Pavlin et al., in 2019, employed computational tools to determine the effects of Y357S mutation on $E R \alpha$ along with the antagonists' effects on the said mutant and to find novel inhibitors against them [237]. Using Ligfilter (Schrodinger Software), the authors filtered the NCI database ( 265,242 compounds) based on Lipinski's Rule and 10 rotatable bonds and further by $\log P$ values that were calculated using QikProp (Schrodinger Software) to improve oral availability of ER $\alpha$ antagonists [227,237]. After running restricted and unrestricted MD using GROMACS5.0.4 to see the behavior of ER mutants Y537S, Y537N and D538G in complex with Endoxifen, AZD-9496 and fulvestrant [44,237]. These models were then docked with the filtered ligand set using Glide HTVS [237]. Top 10\% of the hits generated were docked using Glide SP to select top $10 \%$ of the generated set for subsequent docking using 
Glide XP [43,237]. The compounds were selected on the basis of their GlideScore and a consensus based on whether the compound docked desirably to at least one of the five structures generated previously [237]. The authors also employed the CANVAS protocol that is based on scaffolds defined by them for antagonism [237]. The compounds were screened using Glide XP and selected on the basis of their score and whether they displayed desirable interactions with at least two of the five mutant MD structures $[43,237]$. The selected compounds were experimentally validated using immunoblot analysis, ER $\alpha$ transactivation assay and MTT cell viability assays with a substance called "Compound 19" (Table 2) being the best hit [237]. "Compound 19" could target both wild type and Y537S ER $\alpha$ activity but only at high concentrations [237].

Experimental validation is ultimately needed to confirm the activities of the proposed novel inhibitors as in silico methods lack the ability to completely capture the actions of a ligand in an actual system. However, various simulation packages can help with such predictions. Many groups have employed CADD-based VS but their results remain to be validated experimentally. For instance, in 2012, Istyastono et al. used PLANTS1.2 and Monte Carlo simulations to screen through the compound eugenol with its analogs and dimers [224,238]. In that study, 4-(4-hydroxy-3-(prop-2-en-1-yl)phenyl)-2-(prop-2-en-1-yl)phenol displayed higher ligand efficiency values making it a target for further research and development of a novel ER inhibitor but these claims lacked experimental validation [238]. Likewise, in 2015, they utilized SBDD to identify eugenol analogs as ER $\alpha$ ligands [239]. In a similar study, Muchtaridi et al. (2017) docked chalcEA and its derivatives in line with Lipinski's rule to ER $\alpha$ (pdb entry 3ERT) using AutoDock $[207,240]$. The authors then used 3D pharmacophore modeling (using LigandScount4.1 Advanced validated by actives and decoys taken from DUD-E database) to screen through the derivatives, all of which showed higher docking score than chalcEA $[240,241]$. Derivatives with a similar dimethylaminoethoxy side chain as OHT, had the best scores but lacked experimental confirmation [240].

In an attempt to target mutated ER, in 2016, Munir et al. used LigandScout for preparation of $\mathrm{ER} \alpha$ structure using four pdb structures-1UOM (C381S, C417S and C530S mutations with bound to a tetrahydroisochiolin ligand), 2JFA (M361S, M411S, M483S and M530S with bound raloxifene), 4 XI3 (L372S and L536S with bound bazedoxifene) and 1R5K-for the generation of a pharmacophore model based on common features from all three ligand based models and for generating a model based on mutations from all three proteins [242]. ZINC database was screened to find ligands that fit the pharmacophore model using Ligscree Server followed by Lipinksi's Rule-based filtering to create a ligand database of interest which was docked to the wild-type and the shared mutated protein model with the Patch Dock server [242,243]. The authors were able to obtain 10 hits, out of which three molecules displayed ideal in silico interactions with both wild-type and mutated protein models [242]. Experimental validation should be used for these studies to corroborate these claims, as docking scores are not always reflective of in vivo activity.

Tissue specificity of SERMs for their antagonistic or agonistic profile and E2-independent coactivator binding poses a challenge for using CADD tools for discovering novel modulators. Simulation software such as Simulation plus could be used to explore the tissue specificity problem but it is not an absolute representation of a biological system $[40,41]$. There is also ambiguity of clear pharmacological differences between agonists and antagonists, which makes it harder to discover specific ligands for ER [244].

\subsubsection{Selective Estrogen Receptor Degraders (SERDs)}

To address partial agonistic properties of SERMs, purely agonistic SERDs were later introduced. These compounds intend to cause degradation of ER by competitively binding to the EBS, causing conformational changes that target the ER for degradation, thus downregulating ER in the cell [36]. SERDs have been known to destabilize the ER by changing the H12 conformation such that it increases the hydrophobic surface exposure and inhibits ER dimerization. 
AstraZeneca developed the most widely known and the only approved SERD-fulvestrant-marketed under the name of Falsodex (Table 3). It has been approved as a second line of treatment for advanced hormone dependent $\mathrm{BCa}$ in postmenopausal women. However, there are clinical trial results suggesting that it is effective as a first line treatment in combination therapy in ER $\alpha+$ and/or PR+ tumors as well [245-247]. Fulvestrant inhibits ER dimerization blocking its nuclear localization, even the fulvestrant-bound ER that localizes into the nucleus is transcriptionally inactive [248-251]. Its structure is similar to that of E2 but with an addition of an alkylsulfinyl group as a side chain to disrupt the H12 resulting in increased surface hydrophobicity. Accelerated degradation of ER due to the instability of fulvestrant bound ER results in downregulation of ER in the cell [246,252]. Fulvestrant has a much higher affinity to the ER than tamoxifen with an $\mathrm{IC}_{50}$ of $4.4 \mathrm{nM}$ in inhibition of cell proliferation in ER $\alpha+$ MCF-7 cells and functions in a dose-dependent manner [245,253-255]. Exploring this association may lead to a higher efficacy of the drug. On the other hand, fulvestrant is twice as active on ER $\beta$ as on ER $\alpha$ [166]. In some cases, patients have been shown to develop resistance to fulvestrant that has been attributed to ESR1 or ERBB2 mutations [247]. Moreover, it cannot be administered orally due to poor aqueous solubility and bioavailability and thus has to be delivered intramuscularly through injections which limits the dosage $[250,256]$.

The next generation of orally administered SERDs with high bioavailability are AZD9496, elacestrant, LSZ102 and GDC-0927, as also presented in Table 3. Of those, AZD9496 was identified using iterative SAR by Weir et al. and has been in clinical trials since 2014. The compound exhibits antiproliferative $\mathrm{IC}_{50}$ of $0.03 \mathrm{nM}$ on MCF-7 cells, and is highly selective towards ER [257]. We used MOE to inspect the interaction between AZD9496 and ER $\alpha$ as shown in Figure 8 [42]. In AZD9496 bound complex with ER, the nitrogen atom in the indole ring of AZD9496 forms a strong hydrogen bond with Leu346 residue [257]. The H12 region of ER is destabilized due to acid-acid overlap between the side chain of the molecule and Asp351 which has been attributed to degradation of the protein $[258,259]$. Phase I studies of AZD9496 in advanced ER $\alpha+$ /HER2- BCa patients found the drug to be tolerable and safe [260]. Other studies demonstrated AZD9496 to be comparable to fulvestrant in cell growth inhibition as well as cross-resistant to fulvestrant [261].

Elacestrant/RAD1901 is a SERM/SERD hybrid substance developed by Hattersley et al. for Radius Pharmaceuticals in 2015, and is currently in Phase III trial aiming to compare its safety and efficacy to the standard endocrine therapy in combination with fulvestrant or AI in advanced ER $\alpha+/$ HERsetting [262]. It works in a dose-dependent manner in degradation of ER and exhibits agonistic SERM like activities at doses that do not induce ER degradation [263,264]. It resulted in growth inhibition of MCF-7 cells and ESR1 mutated xenograft models (including fulvestrant and tamoxifen resistant ones) $[263,265,266]$.

Tria et al. synthesized LSZ102 by combining a benzothiophene core such as raloxifene/arzoxifene and a carboxylic side chain from GW-7604, which is a precursor of a previously undeveloped drug etacstil/GW-5638 by Novartis Pharmaceuticals [253]. It is currently in Phase I trials aiming to determine the safety and tolerability as a monotherapeutic agent or in combination with LEE011 (a CDK4/6 inhibitor) or BYL719 (a PI3K inhibitor) in advanced ER $\alpha+$ BCa [267]. Using MOE, we can see that the phenolic hydroxyl group of LSZ102 forms hydrogen bonds with Arg394 and Glu353 residues of ER, while the rest of the core is involved in hydrophobic interactions with the protein (Figure 9) [42,253]. The van der Waal forces due to the difluoroethyl group on the compound result in a conformational change of the Phe 425 side chain increasing the size of the cavity [253]. The bulky side chains of both AZD9496 and LSZ102 cause a conformational change in H12 that ultimately destabilizes the ER thereby inducing degradation [253]. The compound displayed an $\mathrm{IC}_{50}$ of $6 \mathrm{nM}$ in ER transcription and $0.2 \mathrm{nM}$ in ER degradation in ER $\alpha+$ MCF-7 cells. With an IC $_{50}$ of $1.7 \mathrm{nM}$ for inhibition of proliferation of MCF-7 cells, it is significantly more potent than fulvestrant and toremifene [253]. 
Table 3. List of notable selective estrogen receptor degraders.

\begin{tabular}{|c|c|c|c|}
\hline Compound & Structure & Company & Effects \\
\hline Fulvestrant & & AstraZeneca & $\begin{array}{c}\text { Development of } \\
\text { resistance. } \\
\text { Low bioavailability. }\end{array}$ \\
\hline AZD9496 & & AstraZeneca & $\begin{array}{l}\text { High Bioavailability. } \\
\text { Cross-resistant to } \\
\text { fulvestrant. }\end{array}$ \\
\hline Elacestrant & & Radius Pharmaceuticals & $\begin{array}{l}\text { High Bioavailability. } \\
\text { Dose dependent } \\
\text { SERM/SERD hybrid. }\end{array}$ \\
\hline LSZ102 & & Novartis Pharmaceuticals & High Bioavailability. \\
\hline GDC-0927 & & Seragon Pharmaceuticals/Genetec Inc & $\begin{array}{l}\text { High Bioavailability. } \\
\text { Highly active in } \\
\text { tam-resistant cells. }\end{array}$ \\
\hline
\end{tabular}

To target tamoxifen resistant cells, Kahraman et al. synthesized GDC-0927 ( $\mathrm{IC}_{50} 0.1 \mathrm{nM}$ ) for Seragon Pharmaceuticals in collaboration with Genetech Inc. This SERD causes $97 \%$ degradation of $\mathrm{ER} \alpha$ and is highly active in tam-resistant MCF-7 xenografts [268]. In Phase I trials, it was determined that the compound was safe and tolerable in metastatic ER $\alpha+/$ HER- BCa in post-menopausal women including patients harboring ESR1 mutations [269]. The structure of GDC-0927 in complex with ER $\alpha$ has been resolved but the H12 seems disordered in its packing to the rest of the ER as seen in Figure 10a using MOE package $[42,270]$. The authors have not made it clear if this is due to the nature of the compound or the quality of the crystal itself. Apart from that, GDC-0927 forms hydrogen bonds on one side with Glu353, Arg394 and Leu387 and on the other side with His524 along with a hydrogen bond interaction between Asp351 and the azetidine nitrogen in the side chain (Figure 10b) (pdb entry 6PFM) $[42,270]$. 


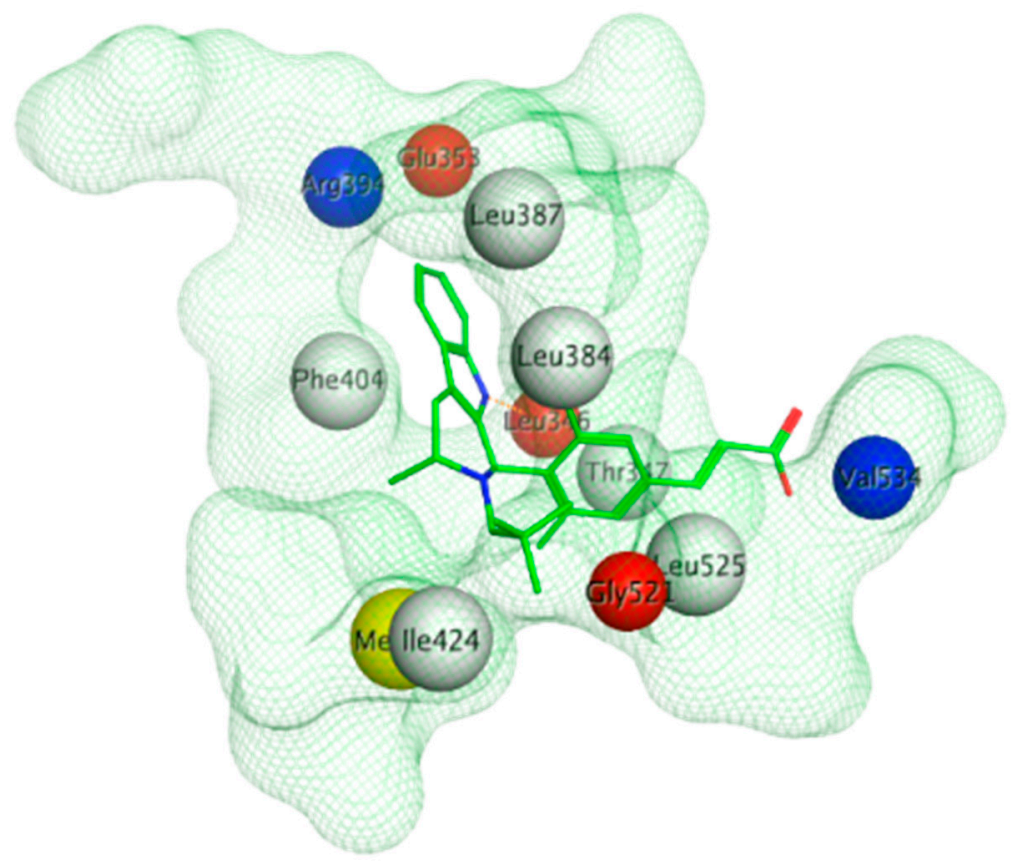

Figure 8. Site view of AZD9496 (green) in complex with ER $\alpha$-EBS (pdb: 5ACC). The indole ring of AZD9496 forms a hydrogen bond (dashed, orange) with Leu346.

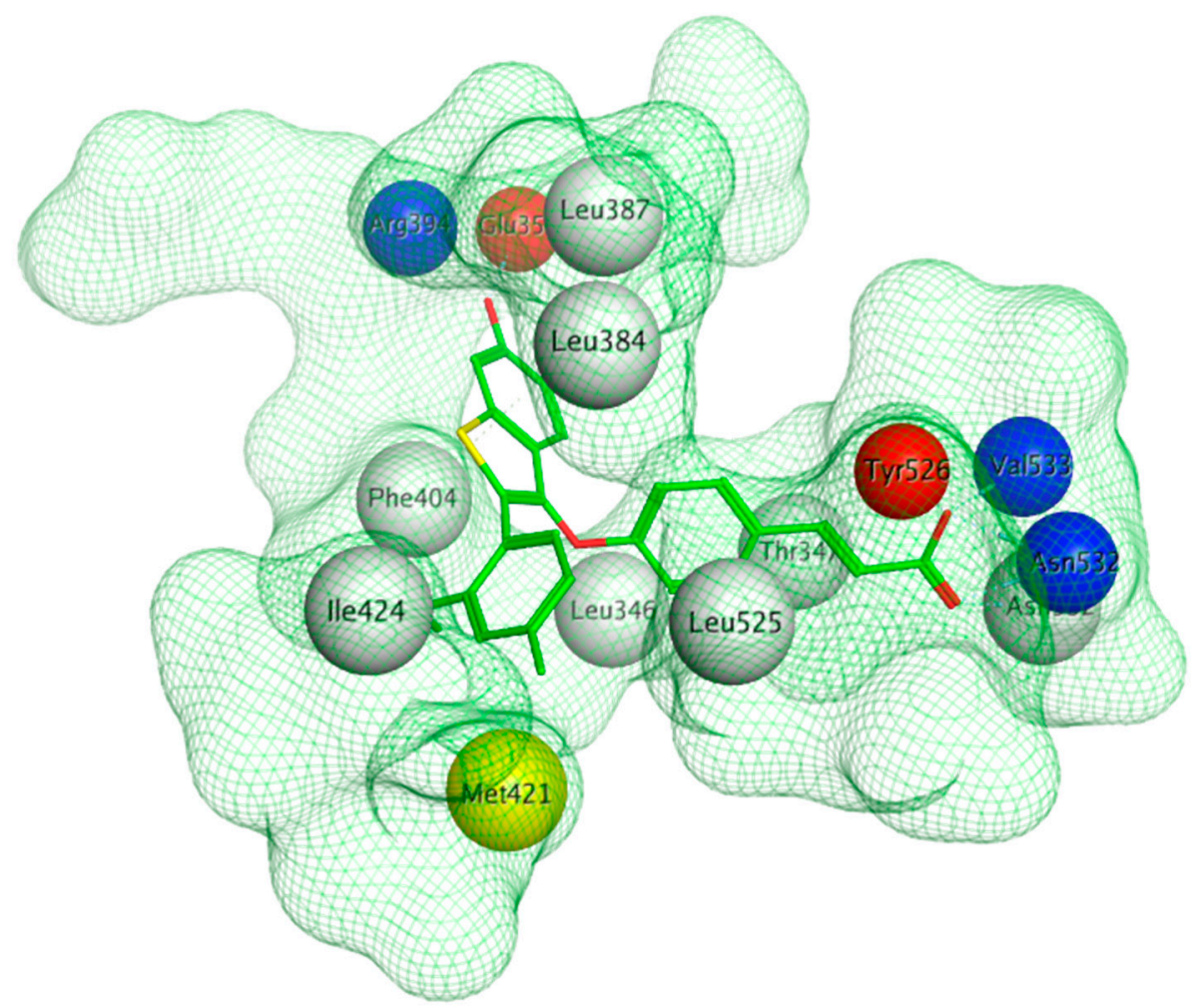

Figure 9. Site view of LSZ102 (green) in complex with ER $\alpha$-EBS (pdb: 6B0F). 


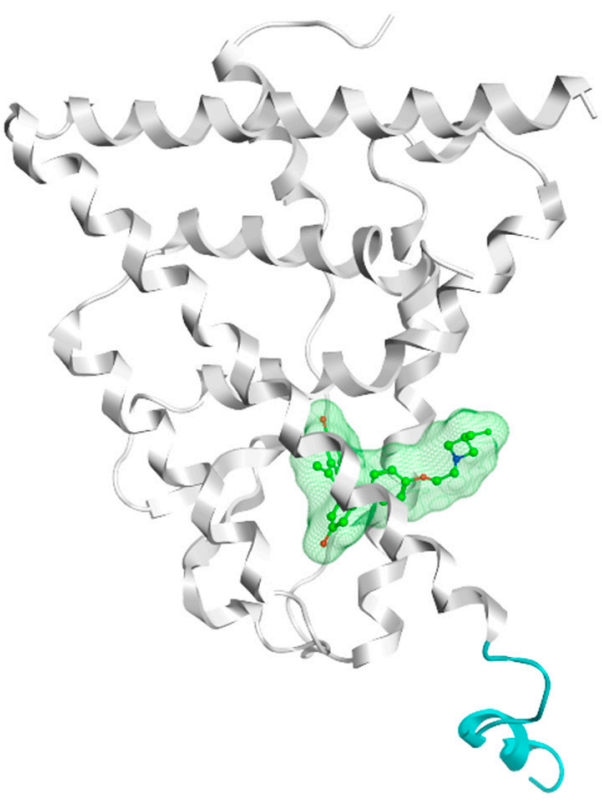

(a)

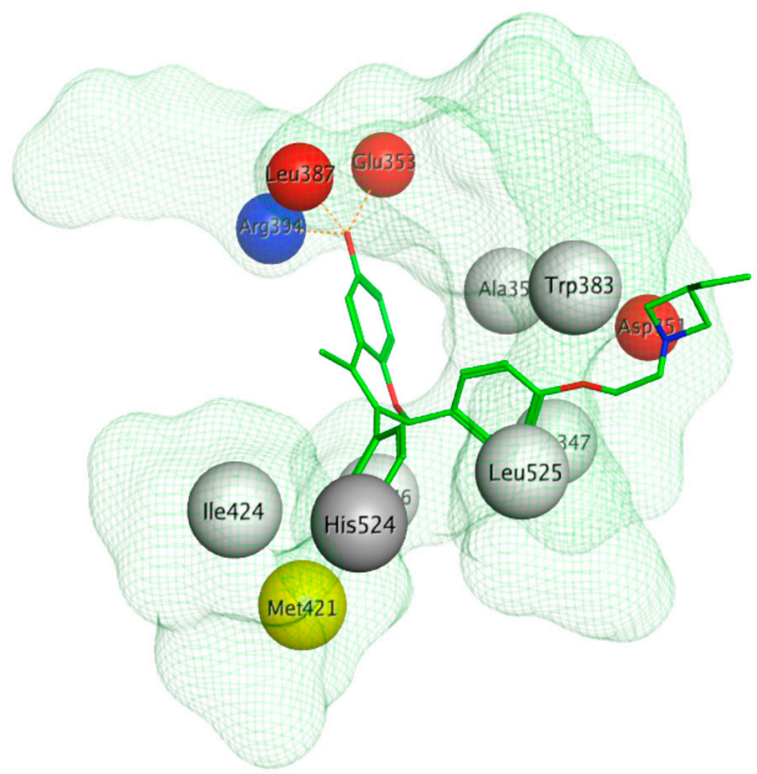

(b)

Figure 10. (a) GDC-0927 (green) in complex with ER $\alpha$ (white) with H12 in cyan; and (b) site view of GDC-0927 (green) in complex with ER $\alpha$-EBS (PDB: 6PFM). The dashed lines (orange) represent the hydrogen bonds formed between GDC-0927 and Arg394, Glu353, Leu387, His524 and Asp351.

To summarize this section, it is necessary to note, that some compounds exhibit dual SERMs and SERDs profiles that make it difficult to clearly differentiate their mode of action. Furthermore, since such SERD molecules bind to the exact same site as modulators, it faces the same challenges for using CADD tools for novel discoveries.

\subsubsection{PROTAC Ligands}

Another marked method for ER degradation is the recruitment of proteolytic E3 Ubiquitin ligase using Proteolysis-targeting chimeras (PROTACs) technology. The use of PROTAC approach would remove any ambiguity that arises from structurally similar SERMs and SERDs. In particular, PROTAC ligands represent essentially two linked active molecules-one binding to the protein to be degraded (in this case, ER $\alpha$ ) called the core, and the other binding to E3 ubiquitin ligase (called a degron). General structure of a PROTAC includes an R1 motif that binds to the protein to be degraded; R2, which is the linker; and R3 is the degron. There has been a newfound interest in repurposing already established small molecule inhibitors specific to the targeted protein for PROTACs (Table 4).

The first PROTAC degrader of ER was reported by Sakamoto et al. (2003) who used E2 linked to I $\mathrm{K} \mathrm{B} \alpha$ phosphopeptide degron (termed as Protac-2) to target ER for mediated degradation with SCF $\beta$-TRCP ubiquitin ligase [271]. Protac-2 treatment resulted in dose dependent ER ubiquitination and degradation by yeast $26 \mathrm{~S}$ proteasomes in vitro but not in vivo due to technical difficulties posed by ER reporter protein expressing cells [271]. In 2008, they developed another compound, PROTAC-B, which was an E2-VHL (von Hippel-Lindau) ligase complex with a HIF-1 $\alpha$ pentapeptide degron which inhibited proliferation of MCF-7 and T47D cell ( $\mathrm{IC}_{50}$ values of $50 \mu \mathrm{M}$ and $16 \mu \mathrm{M}$, respectively, at $72 \mathrm{~h}$ ), but had no effects on ER $\alpha$ - SKBr3 cells [272]. PROTAC-B results in ER $\alpha$ degradation through proteasomes since its activity can be blocked by MG132, while adding E2 in a system with PROTAC-B decreases its ability for ER $\alpha$ degradation [272]. The compound causes G1 cell arrest in MCF-7 and T47D cells as it downregulates cyclin D1 and PR expression [272]. 
Table 4. PROTAC ligands for ER.

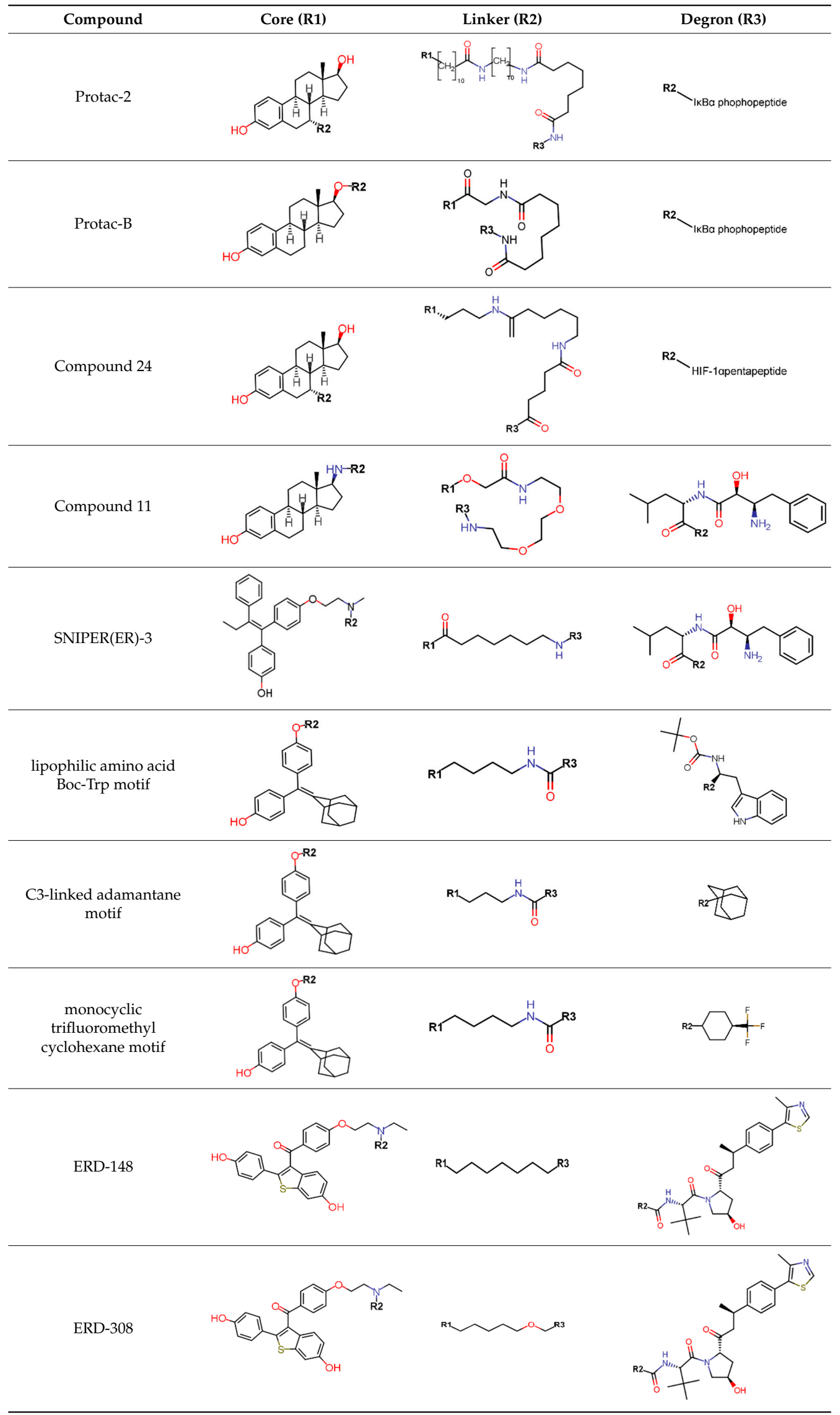


For optimal linker position on E2, Kim et al., in 2010, tested E2 linked to an E3 recognition residue degron at various sites. C-terminal protected PROTAC, protected penta-peptides and C7 $\alpha$ linked compounds provided more substantial degradation. Competitive ligand binding assay suggested that "Compound 24" which was based on C7 $\alpha$ linkage at the E2 had a higher affinity than tamoxifen [273]. In the same year, they synthesized a novel two headed PROTAC molecules with two E2 molecules linked at the previously reported C7 $\alpha$ linkage site with HIF-1 $\alpha$ pentapeptide (VHL ligands) degron causing proteasomal ER $\alpha$ degradation (Figure 11) [274]. Competitive ligand-binding affinity assay established that the two headed PROTAC was three times more active and resulted in higher than fivefold ER $\alpha$ degradation, but displayed poor solubility with respect to its monomeric counterparts with either the $\mathrm{N}$ terminal or $\mathrm{C}$ terminal linkages to the VHL ligand [274].

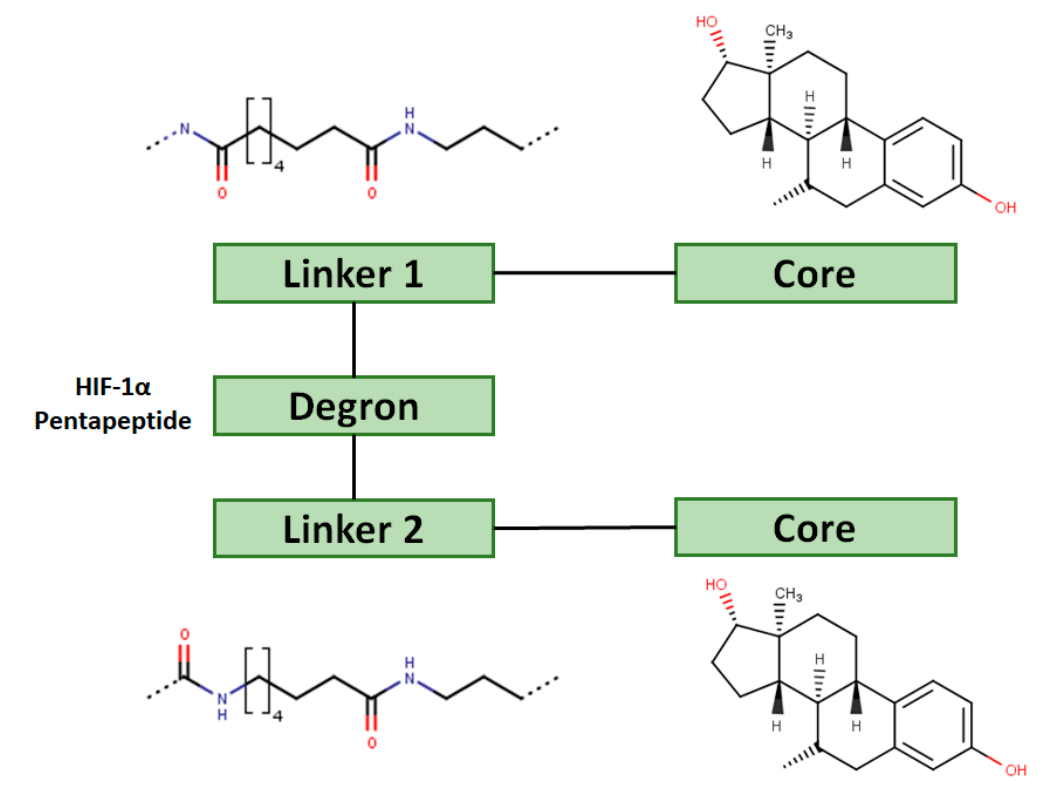

Figure 11. A double headed PROTAC with two E2s to bind to proteins with a common degron developed by Kim et al. [274].

In 2011, Itoh et al. synthesized a new type of PROTAC ligands termed SNIPERs (Specific and Nongenetic IAPs-dependent Protein ERasers) intended for nuclear receptors-retinoic acid receptors, $\mathrm{AR}$ and ER $\alpha$ [275]. Known ER agonist E1 was used for targeting ER $\alpha$ linked to cellular inhibitor of apoptosis protein 1 (cIAP1) ligand degron to create "Compound 11" (Table 4) [275]. Western blots concluded that "Compound 11" downregulated ER $\alpha$ in MCF-7 cells [275]. In continuation of this study, Okuhira et al. developed SNIPERs for ER $\alpha$ degradation and induction of BCa cell death via necrosis in 2013 [276]. The authors used OHT in conjugation with bestatin, a cIAP1 ligand to synthesize three compounds with different linker lengths with similar activity at $6 \mathrm{~h}$ in MCF-7 cells but SNIPER(ER)-3 was found to be more active at $24 \mathrm{~h}$ [276]. At $3 \mu \mathrm{M}$, the compound resulted in increase of ER $\alpha$ levels attributed to OHT's antagonistic SERD-like activity, but, at $30 \mu \mathrm{M}$, the compound downregulated ER $\alpha$ and cIAP1 levels in both MCF-7 and T47D cells, indicating that the compound caused ubiquitylation and further degradation of both ER $\alpha$ and cIAP1 [276]. qRT-PCR on SNIPER(ER)-3 treated cells indicated that the compound successfully inhibited the upregulation in pS2 mRNA stimulated by E2 [276]. The compound induced cell death via necrosis in MCF-7 cells but not in U2OS and HeLa cells or MG132 treated MCF-7 cells indicating that the necrosis was linked to ER $\alpha$ degradation and production of reactive oxygen species [276].

In 2018, an N-terminal aspartic acid cross linking (TD) strategy for stabilizing the peptides and achieving increased cell-permeability was developed by Jiang et al. [277]. They synthesized three peptide-based PROTACs (TD-PROTACs) to target ER $\alpha$ with a TD peptidomimetic ER modulator (TD-PERM) bound to a VHL ligand degron [277]. The peptide TD-PROTAC having a 6-aminohexanoic 
acid linker showed activity immunofluorescence and flow cytometry assays. Immunoblotting was able to establish dose dependent ER $\alpha$ degradation in T47D cells with $\mathrm{DC}_{50}<20 \mu \mathrm{M}$ and showed reduced activity against PR and Vitamin D receptor [277]. The peptide caused proteasome mediated degradation of ER $\alpha$ through ubiquitylation and was found to be active on MCF-7 and T47D cells but not MDA-MB-231 and HEK 293T cells [277]. TD-PROTAC inhibited receptor signaling as supported by a decrease in pS2 mRNA measured using qPCR and induced S-phase arrest in T47D cells [277]. Nude mice xenografted with MCF-7 cells and injected with $10 \mathrm{mg} / \mathrm{kg}$ TD-PROTAC resulted in 75\% reduction in tumor volume in 42 days similar to $4 \mathrm{mg} / \mathrm{kg}$ tamoxifen in comparison with the control untreated tumor [277].

Sharma et al. used an ER $\alpha$ ligand based on previously developed a SERD with 2-3 times more affinity towards ER $\alpha$ than E2 to increase PROTAC activity [278]. The ER ligands were linked to various E3 ubiquitin ligands with either lipophilic amino acid, monocyclic, bicyclic or tricyclic motifs [278]. The lipophilic amino acid Boc-Trp motif resulted in significant anti-proliferative effect $\left(\mathrm{IC}_{50} 16 \mathrm{nM}\right)$ and $\mathrm{ER} \alpha$ downregulation with $\mathrm{IC}_{50}$ value of $0.5 \mathrm{nM}$ [278]. The monocyclic trifluoromethyl cyclohexane motif containing PROTAC could reach an antiproliferative $\mathrm{IC}_{50}$ value of $0.5 \mathrm{nM}$ and ER $\alpha$ downregulation $\mathrm{IC}_{50}$ value of $2 \mathrm{nM}$ while, the C3-linked adamantane motif tested could reach an antiproliferative $\mathrm{IC}_{50}$ value of $9 \mathrm{nM}$ and $\mathrm{ER} \alpha$ downregulation $\mathrm{IC}_{50}$ value of $3 \mathrm{nM}$ [278]. The compounds could downregulate ER $\alpha$ mediated transcription of PR, pS2, and GREB1 mRNA and were active even at higher concentrations [278].

In 2019, Hu et al. developed a PROTAC, ERD-308, using N,N diethylamino raloxifene analog with a cereblon or a VHL ligand for degradation of ER [279]. Initial testing by Western blots confirmed that VHL ligand was more effective as ER degrader resulting in ERD-148 with an $\mathrm{IC}_{50}$ value of $196 \pm 6 \mathrm{nM}$ [279]. Various linkers were tested for optimizing ERD-148's activity leading to linker containing a polyethylene glycol unit, achieving $>95 \%$ inhibition at $5 \mathrm{nM}$ concentration in ER $\alpha+\mathrm{T} 47 \mathrm{D}$ BCa cells and $>80 \%$ degradation at $30 \mathrm{nM}$ in MCF-7 cells [279]. The compound had an $\mathrm{IC}_{50}$ value of $0.77 \mathrm{nM}$ in MCF-7 cells cell proliferation assay with an $\mathrm{I}_{\max }$ value higher than both fulvestrant, raloxifene and elacestrant at $57.5 \%$ which for further evaluated by crystal violet staining and had no effect on ER- MDA-MB-231 cells [279]. Analysis of ERD-308 on MCF-7 cells using qRT-PCR further found that the compound successfully downregulated levels of PR and GREB1 mRNA [279]. The group then synthesized compounds based on ERD-148 by substituting $\mathrm{N}, \mathrm{N}$ diethylamino raloxifene domain with tamoxifen, OHT, bazedoxifene or lasofoxifene but ERD-148 was found to be the most potent among all [279]. Although we could not find any example of this, CADD tools can assist the development of new PROTACS. VS for various cores and degrons along with docking simulations with different cores, linkers and degrons could aide initial testing of these molecules.

\subsubsection{LBD-Directed Covalent Inhibitor}

In the quest for a class of drugs with improved potency and ability to overcome development of resistance to EBS directed drugs, Selective ER covalent antagonists (SERCAs) were also developed. SERCAs inhibit ER $\alpha$ activity by covalently binding to the ER-LBD. Recently, Puyang et al. discovered H3B-5942 (Figure 12), an orally available SERCA that was found to be safe and tolerable in $\mathrm{ER} \alpha+/ \mathrm{HER}-\mathrm{BCa}$ patients in Phase I clinical trials and is currently in Phase II trials [280].

The compound inhibits ER $\alpha$ mediated genes GREB1 and TFF1 on wild type ER $\alpha$ and its mutant forms, Y537S, Y537N, Y537C and D538G [281], while displaying no agnostic activities on endometrial cells as SERMs and SERDs do [281]. This suggests that the mechanism of action of SERCA may be different from traditional EBS directed therapies.

The crystal structure visualized using MOE software demonstrated that H3B-5942 forms covalent bond with Cys530 that is located at the C-terminal end of $\mathrm{H} 11$ and directly involved in AF2 pocket formation (Figure 13) [42,281]. The rest of the H3B-5942 occupies the EBS cavity in the ER-LBD [281]. Combination treatment with CDK4/6 or mTOR inhibitors has shown improved efficacy [281]. However, H3B-5942 could result in Cys530 mutation resulting in decreased efficacy of the drug [281]. The effects 
of this compound on all known forms of ER $\alpha$ mutants are not yet known and may result in resistance via non-genomic signaling as seen in the case of tamoxifen resistance [282].

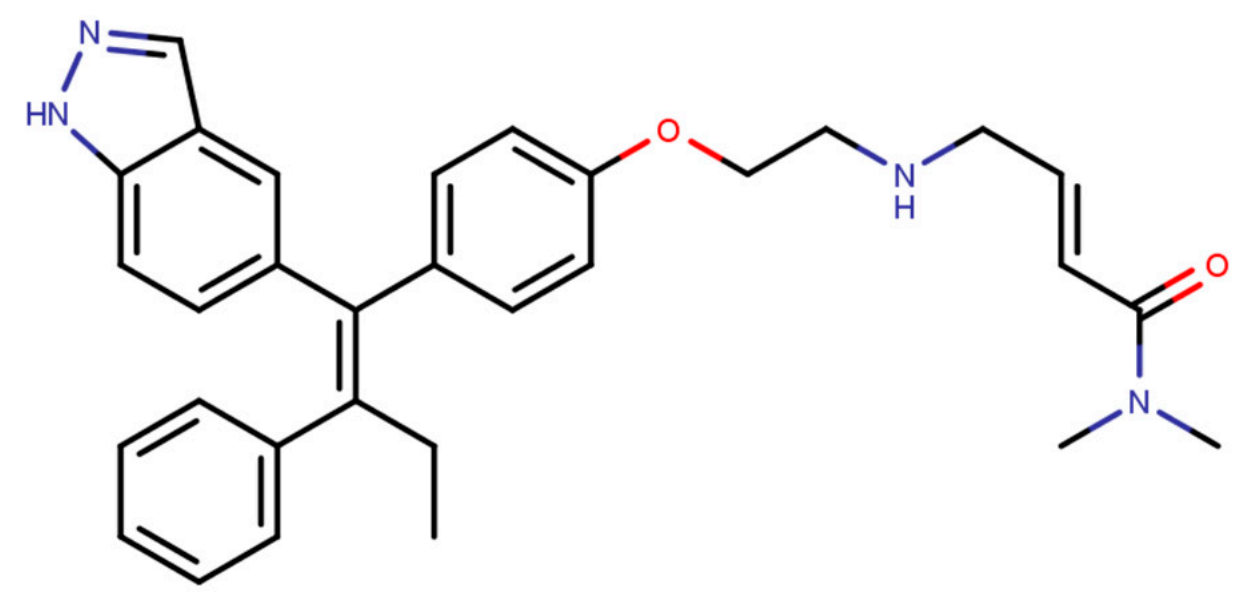

Figure 12. Structure of LBD-directed covalent inhibitor, H3B-5942.

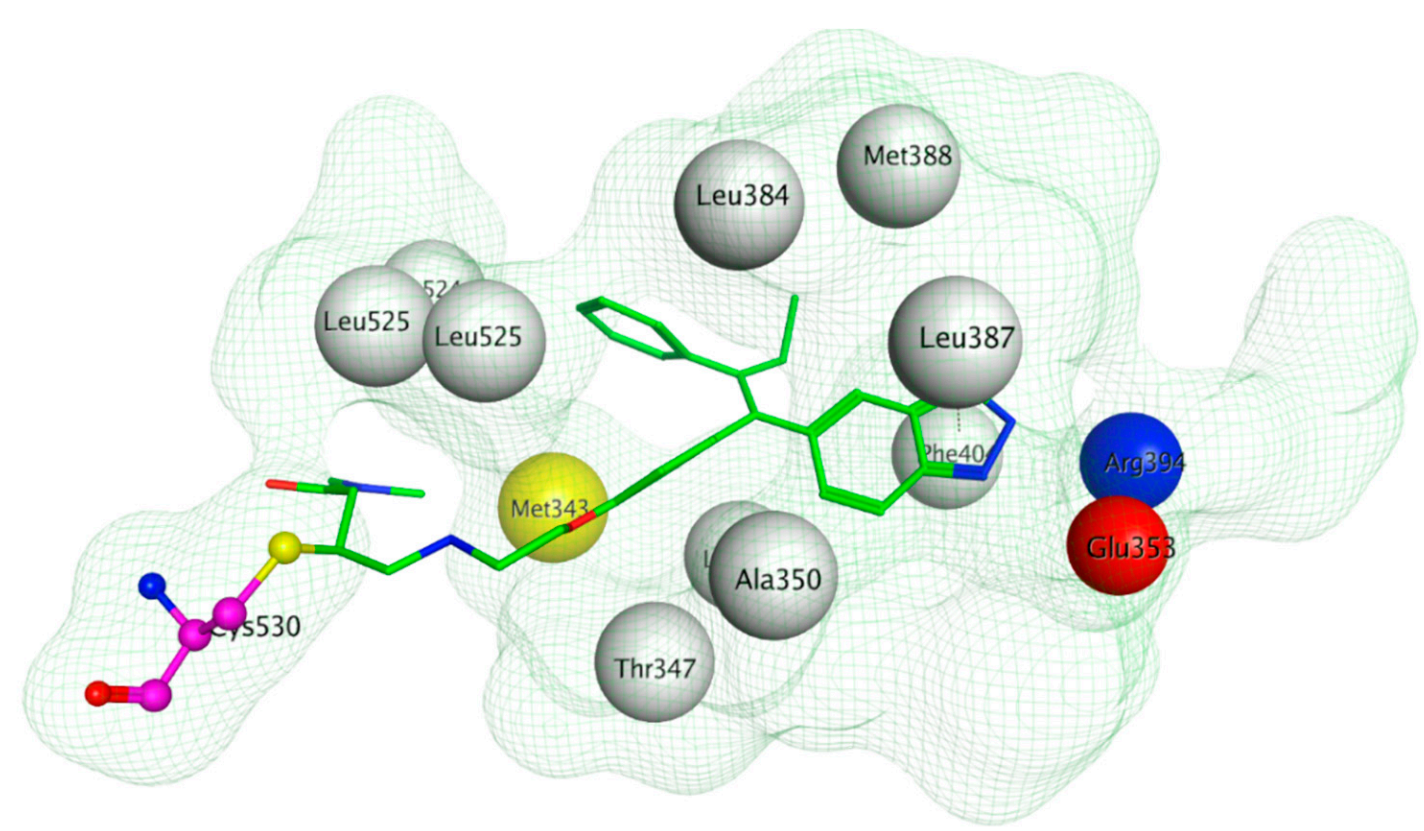

Figure 13. Site view of H3B-5942 (green) in complex with ER $\alpha$-EBS. It forms a covalent bond with the residue Cys530 shown in pink (pdb: 6CHW).

As the previous review sections illustrate, EBS directed drugs for years have been the norm in targeting ER $\alpha$ (Table 5). There are many promising inhibitors currently under clinical trials that are more potent and have less unwanted side effects compared to tamoxifen and fulvestrant. However, these inhibitors have not yet overcome the high frequency of resistance development in BCa cells. Moreover, some mutant forms of ER have been shown to recruit co-regulators and thus be transcriptionally active even in the absence of hormones. Thus, there is still an unmet need to consider targeting other sites on $\mathrm{ER} \alpha$ to overcome the limitations of EBS-directed strategies. 
Table 5. Small molecule ER inhibitors, currently in clinical trials.

\begin{tabular}{|c|c|c|c|}
\hline Compound & Structure & Clinical Trial ID and Phase & $\begin{array}{c}\text { Mechanism } \\
\text { of Action }\end{array}$ \\
\hline Bazedoxifene & & $\begin{array}{c}\text { NCT02448771 (Phase Ib/II) [186] } \\
\text { NCT02694809 (Phase II) [187] }\end{array}$ & SERM \\
\hline Lasofoxifene & & NCT03781063 (Phase II) [190] & SERM \\
\hline Acolbifene & & NCT00853996 (Phase II) [199] & SERM \\
\hline AZD9496 & & $\begin{array}{l}\text { NCT03236974 (Phase I) [260] } \\
\text { NCT02780713 (Phase I) [260] } \\
\text { NCT02248090 (Phase I) [260] }\end{array}$ & SERD \\
\hline Elacestrant & & NCT03778931 (Phase III) [262] & SERD \\
\hline LSZ102 & & NCT02734615 (Phase I) [267] & SERD \\
\hline GDC-0927 & & NCT02316509 (Phase I) [269] & SERD \\
\hline H3B-5942 & & NCT03250676 (Phase I/II) [280] & SERCA \\
\hline
\end{tabular}

\subsection{AF2-Directed Inhibition}

$\mathrm{BCa}$ cells develop resistance to traditional HT over time, and, therefore, targeting alternative sites on ER $\alpha$ may provide effective treatment options. One such target pocket that has been of particular interest is the AF2 functionality of the ER-LBD (Figure 14). It has been demonstrated that 
coactivator $\mathrm{p} 300$ can bind to the AF2 pocket even in the absence of $\mathrm{E} 2$, by using the notch signaling pathway [283]. Moreover, certain ER $\alpha$ mutants have also been shown to be transcriptionally active in the absence of hormone, and therefore such mutants are unresponsive to traditional AI or SERM/SERD therapies $[112,113,115,284]$. Thus, blocking AF2-coactivator interaction could represent a very practical approach to prevent $\mathrm{ER} \alpha$ transcription in drug-resistant $\mathrm{BC}$. In recent years, molecular modeling has advanced tremendously offering an indispensable tool-box for evaluation of small molecule binding sites on surfaces of protein targets. Besides the EBS on ER-LBD, the AF2 site has been visualized by X-ray structures of ER-LBD. The site can be found using MOE SiteFinder, as shown in Figure 14, where small molecule inhibitor can substitute co-activator [42].

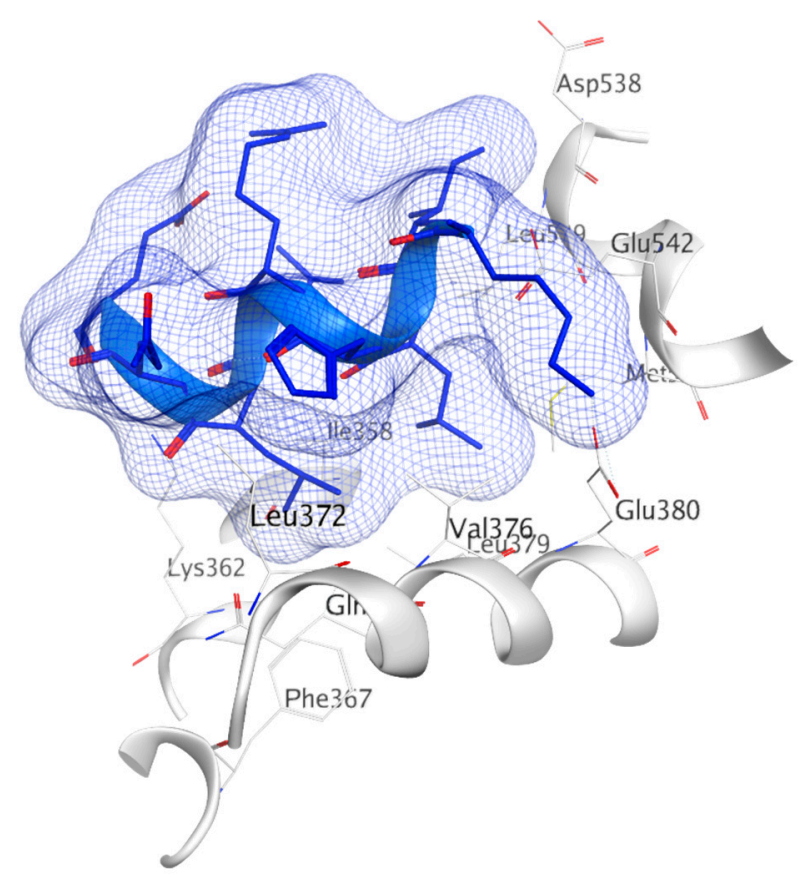

Figure 14. A coactivator peptide LxxLL motif of the coactivator Steroid receptor Coactivator (SRC-1) (blue) docked to AF-2 site on the ER-LBD (white) (pdb: 3UUD).

The AF2 cavity is a well-defined hydrophobic pocket made up of Leu354, Val355, Met357, Ile358, Asn359, Lys362, Phe367, Val368, Leu370, Thr371, Leu372, His373, Gln375, Val376, Leu179, Trp383, Leu539, Glu542, Met243 and Ala546 residues. As discussed above, many co-regulators containing a hydrophobic LXXLL motif similar to H12 interact with this pocket [285].

Recently, Raj et al. discovered ERX-11, which is a highly potent, non-toxic, and bioavailable compound (Table 6) that inhibits ER $\alpha$ via AF-2 mediated mechanism of action [284]. It exhibits $\mathrm{IC}_{50}$ values ranging from 250 to $500 \mathrm{nM}$ for growth inhibition of $\mathrm{ER} \alpha+$ cells and inhibits growth of both wild type and mutant forms of ER $\alpha$ with comparable potency [284]. ERX-11 reduces tumor volume by $73 \%$ in MCF-7-PRLPS1 xenografts. The compound also demonstrates significant activity in Tam-resistant and letrozole-resistant cell lines [284,286]. ERX-11 in combination with a palbociclib (CDK4/6 inhibitor) was found to be more potent in tamoxifen and letrozole resistant cells than either treatment alone $[287,288]$. Lead optimization based on ERX-11 yielded four compounds with nanomolar activity against ER $\alpha$, which are currently being validated in preclinical phase [287]. Essentially, the two iso-butane groups of ERX-11 mimic the LXXLL motif of the co-activator and fill up the volumes of leucine side chains of the LXXLL motif [284]. This compound is one of the most promising compounds developed so far that targets an alternative site on $\mathrm{ER} \alpha$. 
Table 6. AF-2 directed inhibitors.

\begin{tabular}{|c|c|c|}
\hline Compound & Structure & Activity \\
\hline $12 \mathrm{a}$ & & $\begin{array}{c}\mathrm{Ki}=29 \mu \mathrm{M}(\mathrm{FAA}) \\
\mathrm{Ki}=0.91(\mathrm{TR}-\mathrm{FRET})\end{array}$ \\
\hline 18 & & $\begin{array}{c}\mathrm{Ki}=7.1 \mu \mathrm{M} \\
(\mathrm{TR}-\mathrm{FRET})\end{array}$ \\
\hline $11 \mathrm{c}$ & & $\begin{array}{c}\mathrm{Ki}=1.7 \mu \mathrm{M}(\mathrm{TR}-\mathrm{FRET}) \\
\mathrm{Ki}=1.9 \mu \mathrm{M} \\
\text { (Reporter Gene Assay) }\end{array}$ \\
\hline $3 c$ & & $\begin{array}{c}\mathrm{Ki}=1.7 \mu \mathrm{M} \text { (TR-FRET) } \\
\mathrm{Ki}=3.2 \mu \mathrm{M} \text { (Reporter Gene Assay) } \\
\mathrm{Ki}=3.2 \mu \mathrm{M} \text { (M2H Assay) }\end{array}$ \\
\hline $3 d$ & & $\begin{array}{c}\mathrm{Ki}=2.0 \mu \mathrm{M}(\mathrm{TR}-\mathrm{FRET}) \\
\mathrm{Ki}=3.6 \mu \mathrm{M} \text { (Reporter Gene Assay) } \\
\mathrm{Ki}=3.4 \mu \mathrm{M} \text { (M2H Assay) }\end{array}$ \\
\hline $3 e$ & & $\begin{array}{c}\mathrm{Ki}=2.1 \mu \mathrm{M} \text { (TR-FRET) } \\
\mathrm{Ki}=3.8 \mu \mathrm{M} \text { (Reporter Gene Assay) } \\
\mathrm{Ki}=2.2 \mu \mathrm{M} \text { (M2H Assay) }\end{array}$ \\
\hline
\end{tabular}


Table 6. Cont.

\begin{tabular}{|c|c|c|}
\hline Compound & Structure & Activity \\
\hline $1 \mathrm{~g}$ & & $\mathrm{IC}_{50}=2.3 \mu \mathrm{M}$ (Reporter Gene Assay) \\
\hline 7 & & $\mathrm{Ki}=4.2 \mu \mathrm{M}$ (FP assay) \\
\hline ERI-05 & & $\begin{array}{c}\mathrm{IC}_{50}=5.5 \mu \mathrm{M}(\mathrm{M} 2 \mathrm{H} \text { assay, COS7 cells) } \\
\mathrm{IC}_{50}=3.6 \pm 0.6 \mu \mathrm{M}(\mathrm{M} 2 \mathrm{H} \text { assay, HEC- } 1 \text { cells }) \\
\mathrm{IC}_{50}=1.2 \pm 0.1 \mu \mathrm{M} \text { (Reporter gene assay) }\end{array}$ \\
\hline 20 & & $\begin{array}{c}\mathrm{IC}_{50}=1.2 \pm 0.1 \mu \mathrm{M} \text { (Reporter gene assay) } \\
\mathrm{IC}_{50}=2.5 \pm 1.1 \mu \mathrm{M}(\mathrm{M} 2 \mathrm{H} \text { assay, HEC }-1 \text { cells })\end{array}$ \\
\hline 22 & & $\begin{array}{l}\mathrm{IC}_{50}=1.3 \pm 0.1 \mu \mathrm{M} \text { (Reporter gene assay) } \\
\mathrm{IC}_{50}=6.8 \mu \mathrm{M}(\mathrm{M} 2 \mathrm{H} \text { assay, HEC- } 1 \text { cells })\end{array}$ \\
\hline 29 & & $\begin{array}{l}\mathrm{IC}_{50}=1.4 \pm 0.4 \mu \mathrm{M} \text { (Reporter gene assay) } \\
\mathrm{IC}_{50}=2.6 \mu \mathrm{M}(\mathrm{M} 2 \mathrm{H} \text { assay, HEC-1 cells })\end{array}$ \\
\hline VPC-16230 & & $\mathrm{IC}_{50}=2.98 \mu \mathrm{M},(\mathrm{TR}-\mathrm{FRET})$ \\
\hline VPC-16464 & & $\mathrm{IC}_{50}=2.7 \mu \mathrm{M},(\mathrm{TR}-\mathrm{FRET})$ \\
\hline
\end{tabular}


Table 6. Cont.

Compound

Many previous attempts have also been made for targeting this pocket. Thus, in 2004, Katzenellenbogen et al. proposed this site as an alternative strategy to target ER $\alpha$ using small-molecules by showing the inhibitory effects of compounds with pyrimidine core on binding of E2 activated ER $\alpha$ with a labeled SRC-1 Box II peptide using an FP assay [289]. Their best compound (termed as Compound 12A in the paper), displayed Ki values of $29 \mu \mathrm{M}$ which made it unfavorable for further advancement in biological assays or in vivo studies [289]. In 2007, they synthesized bicycle [2.2.2] octanes to target the ER-AF2 site by essentially de novo mimicking the two Leu residues in the binding motifs of SRC [290]. However, the new compounds displayed much lower potency than the previous pyrimidine core with $\mathrm{Ki}$ values ranging $7-40 \mu \mathrm{M}$ compared to $0.91 \mu \mathrm{M}$ for the previously reported "Compound 12A" and $0.19 \mu \mathrm{M}$ for SRC-1 Box II peptide using time-resolved fluorescence energy transfer (TR-FRET) assay [290]. The best hit, named "Compound 18" (Table 6), demonstrated IC 50 of $17.1 \mu \mathrm{M}$ [290]. To improve potency of previously reported compounds, in 2008, the same group continued with SAR studies around the pyrimidine core and reported molecules with improved Ki of 2-3 $\mu \mathrm{M}$ in a TR-FRET assay, with the best molecule, termed "Compound 11c", demonstrating Ki value of $1.7 \mu \mathrm{M}$ [291]. In the same year, amphipathic benzenes, synthesized by mimicking the Leu-rich SRC, demonstrated improved solubility compared to pyrimidines, with most of developed inhibitors (Compounds 3c-e in Table 6) exhibited Ki values of 1.7-2.1 $\mu \mathrm{M}$ in TR-FRET assay and low micromolar Ki values in both reporter gene and mammalian two-hybrid (M2H) assay in HEC-1 cells (Table 6) [292]. In 2011, the group used HTS to identify novel hits with $\mathrm{IC}_{50}$ values in $2.3-5 \mu \mathrm{M}$ range with their best hit "Compound 1g" shown in Table 6 [293]. The authors further studied SAR in the series based on the docking poses generated by Glide and subjected to MD simulation for water displacement and identified that hydrophobic Ile689, Leu690, Leu693 and Leu694 residues in SRC are important for binding to the ER $\alpha$ [293]. The findings suggested that more focus should be put on larger compounds to target his site [293].

In 2007, Becerril and Hamilton also tried to mimic leucine side chains of coactivator peptide to synthesize multiple chemicals out of which "Compound 7" was able to achieve $4.2 \mu \mathrm{M} \mathrm{Ki}$ value in an FP assay [294]. Researchers from Wyeth Pharmaceuticals performed a study that combined high-throughput $\mathrm{M} 2 \mathrm{H}$ assays with virtual screening to identify novel co-activator binding inhibitors [295]. They reported guanylhydrazone compound ERI-05 $\left(\mathrm{IC}_{50}=5.5 \mu \mathrm{M}\right)$ that blocks the interactions of Gal4 DBD/ER $\alpha$ LBD fusion and SRC-1, SRC-3 or SRC-3/VP16 21 fusion in a M2H assay performed in COS7 cells [295]. Although ERI-05 reduced the expression of the ER $\alpha$ regulated gene pS2 in MCF-7 cell line at $20 \mu \mathrm{M}$, it turned out to be toxic at higher concentrations [295]. Subsequently, 
Katzenellenbogen et al. developed a series of guanylhydrazone-based inhibitors based on previously reported activity of the said core with reported inhibition of ER $\alpha$ transactivation in MCF-7 cell line with some showing improved potency over ERI-05 [296]. The compounds produced displayed lower $\mu \mathrm{M} \mathrm{IC}_{50}$ values mostly within 1-8 $\mu \mathrm{M}$ for reporter gene assays and around 2.6-12 $\mu \mathrm{M}$ for M2H assays [296]. Compounds 20, 22 and 29 were some of the best hits, as seen in Table 6 [296]. Since these compounds react covalently with nucleophilic residues in ER $\alpha$, they could not be explored further [296]. Additionally, peptide inhibitors (designed based on LxxLL motif) were reported to inhibit the interaction of ER with co-activators [296]. However, their application is limited by poor permeability and lack of specificity [296].

In 2015, Singh et al. used CADD in the discovery of an ER $\alpha$-AF2-directed compound, VPC-16230, through in silico screening of compounds from the ZINC15 database with Glide (Schrodinger Software) and eHiTs docking $[43,297,298]$. Consensus scoring based on various factors such as- docking score, pKi values, RMSD values for voting along with visual inspection and in vitro testing were used for discovering potential hits [297]. VPC-16230 could significantly decrease mRNA expression mediated by E2, inhibit proliferation of MCF-7 cells at an $\mathrm{IC}_{50}$ value of $7.8 \mu \mathrm{M}$, and Tam-resistant TamR3 cells and TamR6 cells at $\mathrm{IC}_{50} \mathrm{~s}$ of $3.4 \mu \mathrm{M}$ and $6.3 \mu \mathrm{M}$ respectively, with no detected suppression of ER $\alpha$ - MDA-MB-453 and HeLa cells [297,299]. Molecular similarity search using VPC-16230 as a template found another more potent compound VPC-16464 with an $\mathrm{IC}_{50}$ value of $2.7 \mu \mathrm{M}$ [300]. Lead optimization on the basis of VPC-16464 led to VPC-16606, which inhibits ER $\alpha$ co-regulator binding with an $\mathrm{IC}_{50}$ of $0.3 \mu \mathrm{M}$ [300]. It downregulates $\mathrm{ER} \alpha$-dependent mRNA expression and was found to be ER $\alpha$ selective over other SHRs (PR, GR and AR) [300].

\subsection{ER DBD-Directed Inhibition}

Another strategy to inhibit ER $\alpha$ could be to target the ER-DBD functionality, which represents the actual active site of all nuclear receptors. The two regions for small molecular inhibition are P-box or the D-box [79,80]. Compounds causing functional disruption of either boxes may lead to a novel class of ER-directed drugs. Employing the MOE visualization package, the second zinc finger can be seen in Figure 15 [42]. This zinc finger forms the DBD/DBD dimer interface in the DBD and has thus been the target for many inhibitors. The following molecules have been found to be ER-DBD-directed (Table 7).

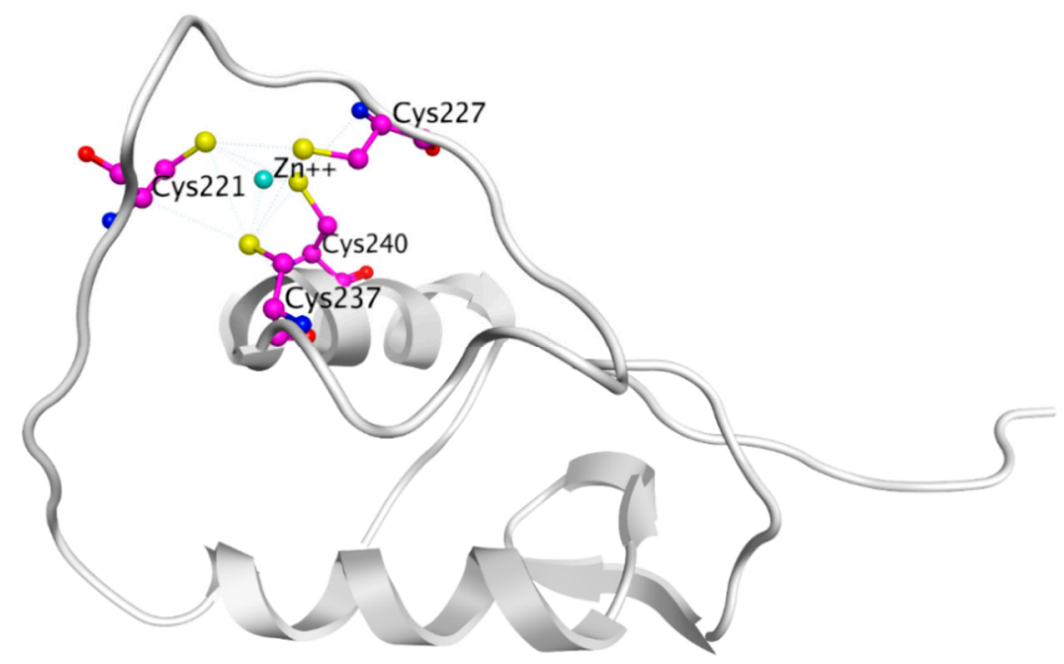

Figure 15. The second zinc finger on the ER-DBD (white). Cys residues are shown in pink (pdb: 1hcq). 
Table 7. DNA Binding Domain targeting compounds.

Compound Structure Zinc Chelator
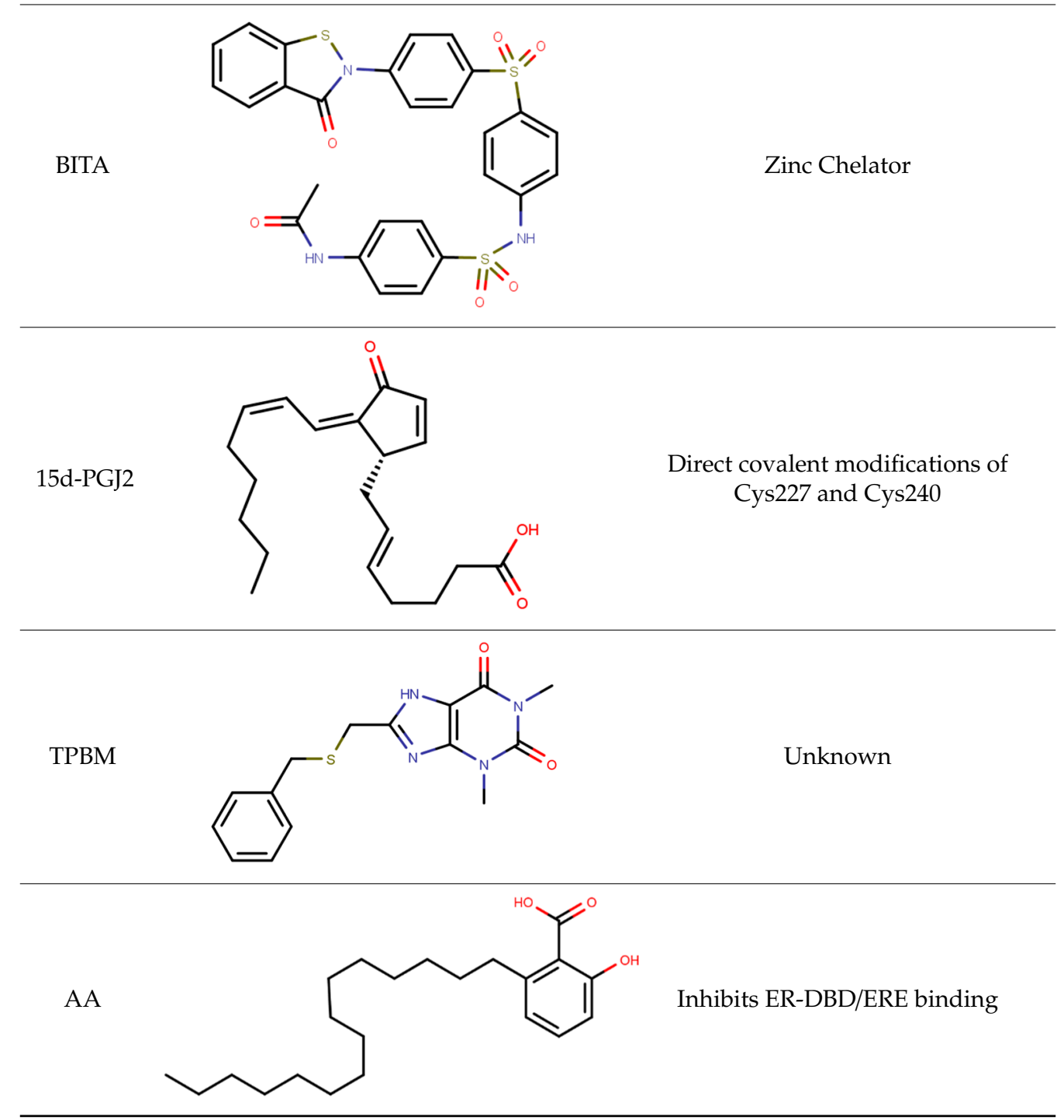

In a paper published in 2003, Wang et al. documented that 2,2' - dithiobisbenzamidine (DIBA) and benzisothiazolone (BITA) treatment of MCF-7, T-47D and ZR-75 cells resulted in the inhibition of E2 driven proliferation of the cells in a dose-dependent manner (Table 7) [301]. In an extended study on the compound DIBA, in 2006, the same authors found that the small molecule was also able to inhibit tumor proliferation, decrease tumor mass in a dose dependent manner at a high dose of $30 \mathrm{mg} / \mathrm{kg}$ and restore tamoxifen sensitivity, which has been attributed to modification induced by DIBA on ER [302]. 
DIBA was also found to selectively inhibit ER activity over other SHRs [301-303]. Inhibitory effects of electrophiles such as DIBA and BITA on Zinc finger activity in tamoxifen-resistant BCa cells have been shown for both ligand independent and dependent signaling (Table 7) [301]. The mechanism of action of DIBA and BITA is to disrupt the labile second ER zinc finger structure in ER by chelation of zinc using weak electrophiles which had been previously studied and documented by Maynard and Covell in 2001 [304].

In 2007, Kim et al. demonstrated that 15-Deoxy-Delta-12,14-prostaglandin J2 (15d-PGJ2), an anti-inflammatory prostaglandin, can inhibit ER $\alpha$ (Table 7) [305,306]. At low concentrations of 0.5-2.5 $\mu \mathrm{M}, 15 \mathrm{~d}-\mathrm{PGJ} 2$ suppressed both E2 dependent and independent proliferation of ER $\alpha+\mathrm{MCF}-7$ cells, but had little effect on ER $\alpha$-MDA-MB-231 cells [306]. However, at higher concentrations $(\geq 5 \mu \mathrm{M})$, it inhibited proliferation in both cell lines [306]. The inhibition of proliferation was attributed to direct covalent modifications of Cys227 and Cys240 in the C-terminal Zinc fingers in the ER $\alpha$ DBD by 15d-PGJ2 and thus disruption of transcription of ER dependent genes [306,307].

A similarly active 8-benzylsulfanylmethyl-1,3-dimethyl-3,7-dihydropurine-2,6-dione (TPBM) was discovered through HTS using in vitro Fluorescence Anistropy Assay (FAA) microplate assay by Shapiro et al. in 2008 (Table 7) [308]. TPBM was found to inhibit ER $\alpha$ DBD binding to fluorescently labeled ERE at an $\mathrm{IC}_{50}$ value of $3 \mu \mathrm{M}, \mathrm{E} 2$ dependent growth in BG-1 cells at an $\mathrm{IC}_{50}$ value of $5 \mu \mathrm{M}$, and $\mathrm{E} 2-\mathrm{ER} \alpha$ mediated gene expression at an $\mathrm{IC}_{50}$ value of $9 \mu \mathrm{M}$ [308]. The compounds were ineffective for hormone independent growth of BG-1 cells and was non-toxic to ER $\alpha$-MDA MD-231 cells [308]. It was further demonstrated that the inhibitor is noncompetitive and selective toward ER over other SHRs (AR, PR and GR) [308]. The mechanism of action of TPBM is still unknown, but it was shown to be different from other DBD targeting molecules such as DIBA, a Zinc finger-chelator [308,309].

Inhibitory effects of Anacardic acid (AA) on ER $\alpha$ was found by Schultz et al. in 2010 using an electrophoretic mobility shift assay (Table 7) [310]. Molecular modeling with surflex docking suggested that AA inhibits ER-DBD/ERE binding [310,311]. In subsequent studies, Li et al. (2015) and Zhao et al. (2018) found that AA downregulates CDK-4 and induces inhibition of Hsp90 causing cell cycle arrest in MDA-MB-231 cells [312,313]. AA exerts noncompetitive inhibitory effects on proliferation of E2 dependent and independent cancer cells and also tamoxifen-resistant cancer cells [310]. Selectivity of AA towards ER over other SHRs has not been assessed. AA inhibited both ER $\alpha$ and ER $\beta$ binding to ERE with IC $_{50}$ values of 13.5, 5.3, and $14 \mu \mathrm{M}$ in ER $\alpha+$ cell lines MCF-7, LCC9 and LY2, respectively, and 29 and $39 \mu \mathrm{M}$ in ER $\alpha-/ E R \beta+$ cell lines MCF-10A and MDA-MB-231, respectively [309,310,314].

Thus far, no group has tried using CADD for DBD-directed inhibition as there has not been a widespread interest in developing these inhibitors. CADD tools could prove useful in discovering selective inhibitors for ER.

\subsection{Dimer Inducers}

ER has the ability to form both heterodimer and homodimers with ER $\alpha$ homodimers promoting cell growth and $E R \beta$ homodimers and $E R \alpha / E R \beta$ heterodimers inhibiting the same. Inducing $E R \beta$ homodimers and $\mathrm{ER} \alpha / \mathrm{ER} \beta$ heterodimers and decreasing $\mathrm{ER} \alpha / \mathrm{ER} \alpha$ homodimer formation using small molecules would therefore represent a viable strategy for BCa inhibition [315,316]. In an intriguing development, $\mathrm{Xu}$ and group developed a bioluminescence resonance energy transfer (BRET) assay to distinguish compounds on the basis of their ability to form different dimers and found that phytoestrogens, cosmosiin and angolesin, transcriptionally activate ER $\alpha / E R \beta$ heterodimers at 1 and $10 \mu \mathrm{M}$, respectively (Figure 16a,b) [315-317]. They inhibit proliferation and migration of cells expressing both $E R \alpha$ and ER $\beta$ but not of ER- or ER $\alpha-/ E R \beta+$ cell lines [317]. Dimer formation was quantified using the BRET assay [315,316]. Elaborating on their previous work, the same group in 2018 used the same assay to screen flavonoids that displayed activity in reporter-based assays in T47D-KBluc reporter cell line for their dimerization selection $[315,318]$. Seven compounds (including cosmosiin) were then used to build a pharmacophore model using GALAHAD software [318,319]. The best pharmacophore model was chosen on the basis of Pareto ranking (pharmacophore-based similarity), 
energy and steric score providing a model with seven essential features including three acceptor atoms, one donor atom and three hydrophobic centers on phenyl and benzopyran rings of cosmosiin [318]. The models were then converted to 3D search query using UNITY-3D (SYBYL software) and used for a non-restrictive, flexible screening through Maybridge and Chembridge databases (taken from ZINC database) producing a list of hits that fit the model [318]. Qfit and SYBYL were used to rank compounds that fit all seven features of the pharmacophore model (167 compounds), purchasing the top 22 hits [318,320]. T47D-KBluc reporter based assay was again used to confirm their activity and BRET assay in HEK293 cells for their preferences giving four compounds (Compounds 4, 6, 9 and 10, as named in the paper) that selectively induce ER $\alpha / E R \beta$ heterodimers at $1 \mathrm{M}$ [318]. "Compound 4" and "Compound 6" displayed high $\mathrm{IC}_{50}$ values for both ER $\alpha$ and ER $\beta$, while $\mathrm{IC}_{50}$ values of "Compound 9" were 1.4 and $2.0 \mu \mathrm{M}$ and "Compound 10" were 1.9 and $3.2 \mu \mathrm{M}$ for ER $\alpha$ and ER $\beta$, respectively (Figure 16c,d) [318].<smiles>O=C1C=C(c2ccc(O)cc2)OC2C=C(O[C@@H]3O[C@H](CO)[C@@H](O)[C@H](O)[C@H]3O)C=C(O)C12</smiles>

(a)<smiles>COc1ccc(-c2c(-c3ccccc3)oc3cc(O)ccc3c2=O)cc1</smiles>

(c)

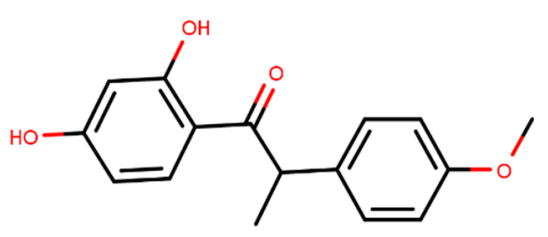

(b)<smiles>CCCc1oc2cc(O)ccc2c(=O)c1Oc1ccc(F)cc1</smiles>

(d)

Figure 16. (a) Cosmosiin; (b) angolesin; (c) Compound 9; and (d) Compound 10.

\subsection{Targeting $D B D / L B D$ Interface}

The LBD/DBD interaction surface is essential for ER transcription; thus, disruption of the interdomain crosstalk has been proposed as another strategy to inhibit ER function. Ile326, Tyr 328, Trp393, Glu397, Leu403, Pro406, Asn407 and Leu409 of the ER-LBD make up the interface that interacts with residues Tyr 191, Trp200, Tyr195, Val199 and Gly198 of ER-DBD [321]. Wells et al. (2007) explored the surface using hydroxyl radical-based protein footprinting, computational modeling and site-directed mutagenesis [321]. Site directed mutations in the implicated ER-LBD interface (I326A, Y328A, P406A, and L409A, see Figure 17a) have been shown to inhibit E2 dependent transactivation without hampering the ability of the ER to bind to E2 and the coactivator proteins [321]. More importantly, MOE SiteFinder has detected small molecule binding sites on ER-LBD and ER-DBD (shown in Figure 17a,b, respectively) [42]. The site on ER-LBD seems more functionally prominent. To design small molecule inhibitors for direct disruption of the LBD/DBD interaction, more functional and structural knowledge is required. 


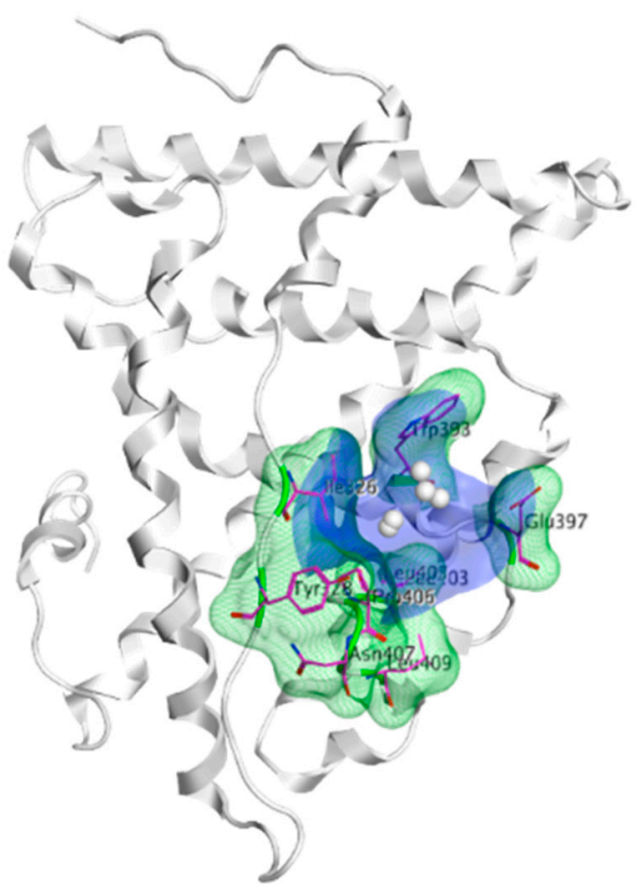

(a)

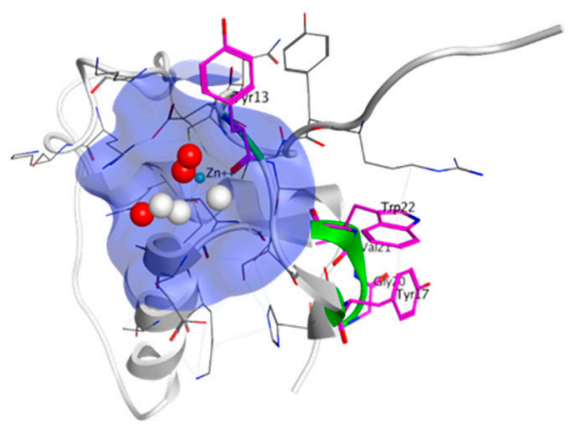

(b)

Figure 17. (a) The important residues (green surface, pink atoms) of ER-LBD that interact with ER-DBD. The identified binding site is shown in blue. (b) The important residues (green ribbon, pink atoms) of ER-DBD interacting with ER-LBD.

\subsection{Targeting F-Domain}

The F-domain interaction with regulatory proteins such as 14-3-3 family of proteins reduces E2 independent transcription and inhibits ER dimerization [99]. Enhancing this interaction increases the 14-3-3 inhibition effects on the ER dimerization, which should result in a great strategy to inhibit $E R \alpha$ [99]. Thus, in 2013, De Vries-van Leeuwen demonstrated that the small molecule of fusicoccin stabilizes the binding of F-domain to 14-3-3 protein, as shown in Figure 18 [99]. Fusicoccin acts as a "molecular glue" between the F-domain and 14-3-3 interaction. The binding site of the molecule is the mode-III site consisting of Asp215, Lys49, Lys122, Leu218, Ser45, Met22, Glu14, Leu43, Asn42, Phe119, Ile169 and Lys214 residues, as shown in Figure 18, with the help of MOE visualization package, where fusicoccin forms H-bonds with Asp215, Lys49 and Lys122 of the 14-3-3 protein [42,99].

Recently, Sijbesma et al. attempted to target this interaction using site-directed small fragment-based screening [100]. The phosphopeptide (mimicking ER $\alpha$ F-domain) interaction with 14-3-3 were stabilized by about 40 times using disulfide fragment tethering of the native Cys 38 and the two mutated Cys42 and Cys45 [100]. 


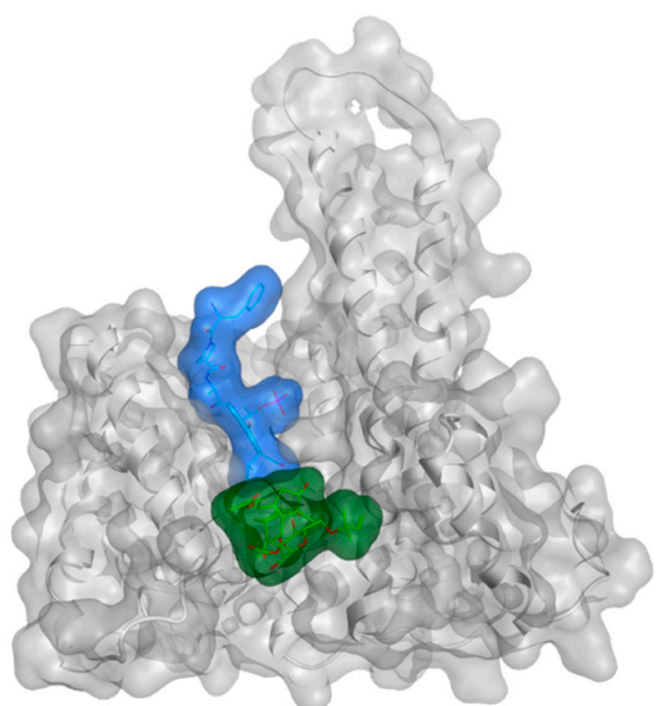

(a)

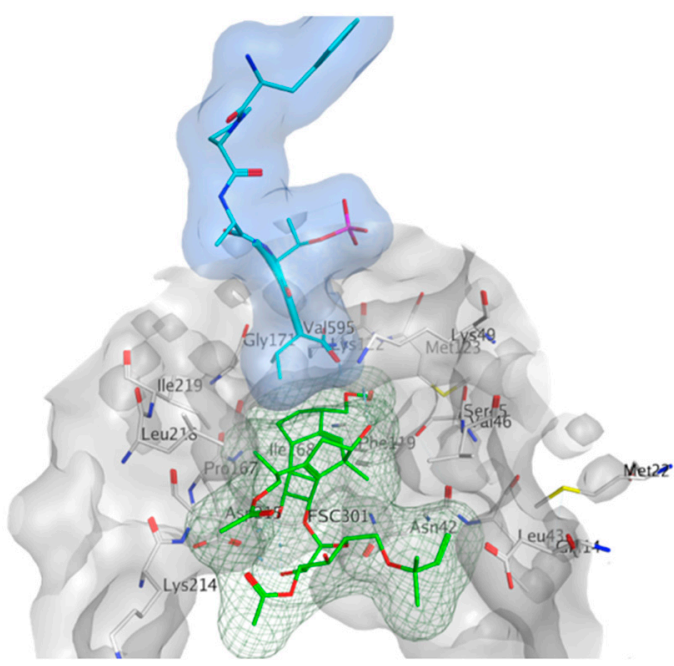

(b)

Figure 18. (a) Fusicoccin (green) stabilizing ER $\alpha$ (Blue) and 14-3-3 (grey) complex (pdb: 4JDD); and (b) site view of fusicoccin (green) interaction with ER $\alpha$ (blue) and 14-3-3 (grey) (pdb: 4JDD).

\subsection{Targeting Binding Function-3 (BF3)}

Based on the homology between ER and AR, a potential small molecule binding BF3 site has been proposed using MOE software, although no experimental evidence of the BF3 functionality has been provided yet for ER, as it has been previously established for AR [42,322-325]. Due to functional similarity between the SHRs, the dynamic nature of the BF3 site in AR could be translatable to ER as well. The residues making up the pocket are more distinct in the ER compared to the other SHRs [326]. In ER, a helix in the hinge region folds onto the ER-LBD in the crystal, blocking the prospective BF3 region [89]. If the helix is removed from the potential BF3 pocket, the pocket is of similar structure and depth and is recognizable by MOE SiteFinder (Figure 19) [42]. Thus, future exploration of ER BF3 area is needed to deny or confirm druggability and functional relevance of that area.

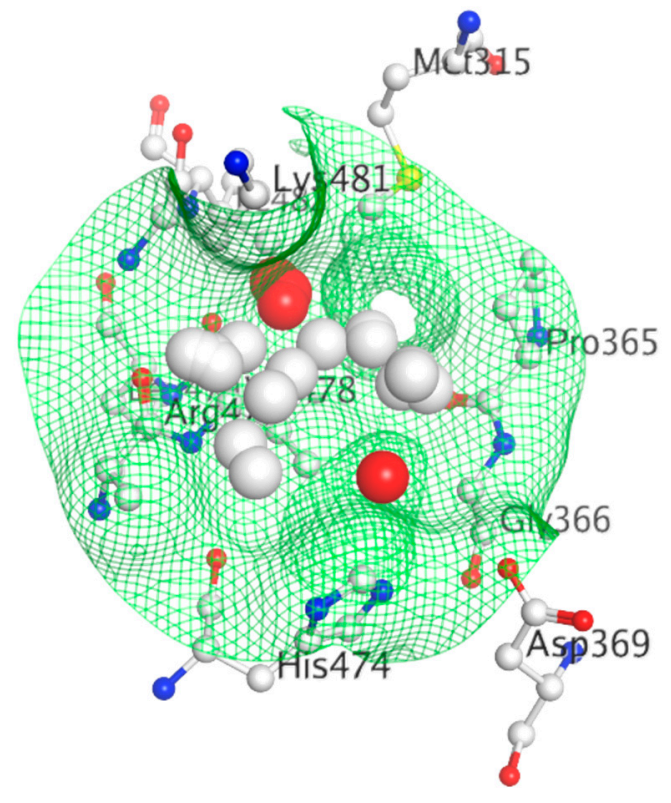

Figure 19. Location of potential BF3 site on ER-LBD fold (pdb: 3UUD). 


\section{Benchmarking ER Ligands}

\subsection{ER Decoy Datasets}

One of the most widely used datasets for benchmarking CADD studies around ER are DUD and DUD-E $[327,328]$. Such datasets are important for training ER activity predictive models and for validation of docking experiments.

In 2006, Irwin et al. chose 40 target proteins to create DUD set with 36 decoys each generated from 2950 known ligands for these proteins as benchmarking sets for molecular docking including both ER agonists and antagonists [327]. ER target docking with DOCK3.5.54 was able to achieve an Enrichment Factor (EF) of $\sim 100$ for the top 98 molecules (which contained four known antagonists) [327,329]. In comparison with Rognan decoy dataset, Jain Decoys and MDDR decoys, the DUD dataset displayed inferior EF performance [327]. The authors attributed this to alleged easier decoys in the other datasets based on their physical properties such as variation in molecular weight category as seen in all the other decoys or lack of hydrogen binding properties as seen in Rognan's decoys [327]. As mentioned above, Niinivehmas et al. used this dataset for their virtual screening pipeline [225]. In fact, Durrant et al. in 2015 used known ER agonists and antagonists from DUD and decoy compounds from NCI diversity set III to propose a novel neural network based scoring function to predict 39 novel ER ligands with the best hit, NCI-19136, reaching Ki value of $490 \mathrm{nM}$ on ER $\alpha$ [330]. However, DUD has imbalanced net formal charge between ligands and decoys. The dataset also contains some false decoys that are confirmed binders due to shortcomings in property matching which could decrease the enrichment [331,332]. Vogel et al. and, Wallach and Lilien in 2011 tried to address this problem by building datasets DEKOIS (demanding evaluation kits for in silico screening) and Virtual decoy set (VDS), respectively [331,332].

Shoichet et al. (2012) extended the DUD database naming it DUD-E for 102 proteins, including ER with 50 decoys for each 22886 ligands [328]. They addressed the decoy and ligand similarity issue by using CACTVS fingerprints along with ECFP4 or daylight fingerprint for filtering out false decoys [328]. They also fitted the decoys to possible local chemical space of the ligands and added net charge was better solvation and electrostatic properties, which as seen in case of ER resulted in a higher $\log$ of the area under the receiver operating characteristic curve (AUC) value [328]. The improved property matching of molecular weight, hydrogen bond behavior, number of rotatable bonds, net charge and MiLogP between decoys and ligands was able to yield a better dataset with higher EF values than DUD [328]. As discussed above, Istyastono et al. (2012) and Pang et al. (2018) used the DUD-E database for virtual screening $[229,238]$. Moreover, in 2017, Istyastono and group used the DUD-E database for the validation of their three unbiased Virtual screening pipelines [333].

It should be noted that decoy datasets are prone to biases, such as "analog bias" that could arise due to the lack of variability in the decoys; "complexity bias" due to structural differences between the actives and decoys; and "false negative bias", which is due to the mixing of active compounds into the decoys datasets resulting in undervaluation of models being evaluated [334]. Using highly filtered methods for selecting decoys and introducing true negatives into the datasets can help in combating these biases thus resulting is improved benchmarking datasets.

\subsection{Endocrine Disruptor Program-ToxCast, Tox21 Datasets}

Another marked benchmark dataset of ER ligands was generated within the EPA Endocrine Disruptors Program. It is a national initiative originated in 1996 when a Endocrine Disruptor Screening and Testing Advisory Committee was set up to come up with a consensus screening and testing protocol for red-flagging possible endocrine disruptors for the safety of American public under the Food Quality Protection Act [335].

A two-step approach is taken for the screening of potential endocrine disruptors in commercial chemicals, pesticides and environmental contaminants. Firstly, common chemicals that can potentially interact with the human endocrine system are identified. The EPA introduced ToxCast (Toxicity 
ForeCaster), a forecaster HTS method to prioritize compounds for screening based on concentration and bioactivity in cells or proteins that are exposed to the compounds using automated HTS [336,337]. The EPA also set up a joint initiative, Tox21 (Toxicology Testing in the 21st Century collaboration) program, with the NIH and the FDA which resulted in a larger library of compounds that are tested for their toxicity in humans [338]. This program was aimed to prioritize chemicals for further testing using automated screening through environmental compounds.

In 2014, Huang et al., as part of Tox21 initiative measured ER modulating activity (agonistic or antagonistic) for $\sim 10000$ compounds, using BG1 cells and ER $\alpha \beta$-lactamase reporter assays in HEK293 cells [339]. In 2016, Huang et al. built a model for toxicity end point predictions using information from the SAR of 10,000 Tox 21 compounds by in vitro tests at 15 concentrations to help prioritize compounds for testing [340]. Judson et al. in 2015 outlined and proposed a computational method to integrate results from 18 different in vitro HTS assays, including Tox 21 and ToxCast that had been carried out for chemical activity on ER to prioritize chemicals for testing integrated for these different assays [341]. Secondly, the prioritized compounds generated from the model are then screened for their activity on estrogen, androgen and thyroid system to quantify the dose dependent adverse effect relationship [335]. After years of validating pipelines and protocols, as of 2015, the EPA has released a list of around 1800 compounds as potential endocrine disruptors for ER [342].

Subsequently, datasets accumulated from various sources, including the Endocrine Disruptor Program, were used in CERAPP (Collaborative ER Activity Prediction Project). CERAPP was a collaborative modeling initiative that resulted in 40 categorical and 8 continuous models from 17 research groups for prediction of ER activity of 32464 chemicals [342]. The models were trained on datasets from Tox 21 collaboration and the ToxCast HTS data with about 1677 compounds categorized as ER agonists, antagonists or binders [342]. The prediction database was curated using 32,464 unique entries that humans could be exposed to from U.S. EPA chemical product categories database, Distributed Structure-Searchable Toxicity list, Canadian Domestic Substances list, Endocrine Disruption Screening Program and U.S. EPA's Estimation Program Interface [342]. The experimental evaluation set consisted of 7522 unique entries for categorical models and 7253 for continuous models taken from Tox21, U.S. FDA Estrogenic Activity Database, Ministry of Economy, Trade and Industry (Japan) database and ChEMBL database [342].

The models were divided into three classes based on their prediction ability: 21 categorical and 3 continuous for binding models, 11 categorical and 3 continuous for agonist models and 8 categorical and 2 continuous for antagonist models [342]. A consensus pipeline was then set up to combine categorical model results into active or inactive and continuous models into very weak, weak, moderate or strong based on their activity for each class, followed by a consensus of many of these models with literature evaluation set taken from more than six sources and resulted in balanced accuracy of 0.91 [342]. The authors concluded that no QSAR or docking model could achieve 100\% accuracy due to major issues in discrepancy in the literature and misclassification of very weak compounds due to not being tested in high enough concentrations [342]. In total, 4001 compounds were classified as actives and 28,463 as inactives which were further prioritized by activity using continuous consensus model [343].

Since then, many other researcher groups actively used Tox21, ToxCast and the CERAPP data in their CADD investigations. For instance, in 2016, Ribay and researchers from Rutgers University used the Tox21 dataset to train prediction model based on QSAR models to predict activity of compounds [344]. Ruiz et al. (2017) proposed consensus models based on the library of tier I endocrine disruptors from the US endocrine disruptor program and the training dataset from CERAPP to evaluate these datasets with the help of QSAR and docking for both AR and ER [345]. Similarly, Russo et al. in 2018, used datasets from ChEMBL, Pubchem and CERAPP (agonist and antagonist) to compare classic machine learning models such as AdaBoost, Bernoulli naive-Bayes, random forest, support vector classification and deep neural network models with varying layers, using five-fold validation [346]. They concluded that the random forest model performed the best over DNNs, thus suggesting that 
simpler machine learning algorithms are enough for ER binding predictions [346]. In the same year, Fernandez et al. developed a deep learning model on Tox21 dataset to predict compound toxicity for both AR and ER, based merely on molecular images [347]. In 2019, Francesco et al. created DeepDocking, a QSAR-based method allowing to predict docking scores for 1.36 billion ZINC15 molecules against ER-AF2 target site [348].

To summarize this section, we could postulate that further improvements in the structure-based CADD methods, pharmacophore-based models and larger training sets provided by large scale initiatives such as the Endocrine Disruptor Program and CERAPP initiative should further improve accuracy of ER $\alpha$ ligand predictions and could result in novel BCa drug candidates.

\section{Future Perspective}

SERMs and SERDs have been the main focus of drug development for ER for over 40 years, with all currently approved ER-directed drugs falling under these two categories. Research and development on SERMs and SERDs have cumulated but there is still room for improvement. In recent years, alternative chemotypes have been discovered that could result in subsequent generations of SERMs with higher potencies and less side effects [349]. However, long-term treatment with currently popular SERMs and SERDs may lead to development of resistance in BCa cells. Thus, alternative ER-targeting strategies have gained a momentum in recent years, as they may offer compounds that can overcome the resistance. Another way to approach this would be target alternative sites on the ER as we have recently attempted for AR [325,350-355].

The use of CADD approaches become invaluable support in such novel endeavors, among which the following might represent a particular promise:

1. Targeting the AF2 site: Blocking co-regulatory protein binding may potently inhibit co-regulator mediated ER transcriptional activity. This presents the most promising alternate site with a well-defined targetable cavity (Figure 14). The use of SBDD with a larger chemical database to screen through could result in diverse active chemotypes and lead compounds that have not yet been explored. Although significant progress has been made in AF2-site drug discovery in recent years, until now only the empirically designed ERX-11 has reached later stages of drug development pipeline, presenting a promising candidate for successful inhibition of BCa cells (Table 6) $[287,288]$. However, we are yet to see a small molecule inhibitor that has reached the clinical trial phase. Furthermore, screening protein-protein interaction libraries could also result in high hit rates as these libraries mimic protein interactions and have been shown to be advantageous over small molecule inhibitors for larger sites [356-358].

2. Targeting the F-region: Targeting this domain by enhancing the protein-protein interaction between the F-domain and 14-3-3 protein interaction interface could exert the desired selectivity in inhibition of ER $\alpha$. Any molecule that enhances this interaction would increase the inhibitory effects of 14-3-3 on ER $\alpha$. As discussed above, fusicoccin has shown inhibitory effects but displays very poor potency (Figure 18) [99]. Finding a potent protein-protein interface enhancer is challenging. Using a large chemical library with the help of DeepDocking would increase the chances of finding novel and diverse "molecular glue" molecules against this large binding site [348]. This strategy may very well help in alternative inhibition of ER activity through AF1 inhibition.

3. Targeting the potential ER-DBD P-box and D-box binding sites: Even though these two binding sites are potential for discovery of new inhibitors, it is challenging. Only a handful of inhibitors have been developed for targeting this domain with all focusing on the second zinc finger (Table 7). AA presents itself to be the strongest candidates of all but still display low potency, making it clinically unviable [310,312-314]. This site is challenging for both CADD and empirical-based approaches. Validation of these two sites for binding of small molecules is required to define a strong targetable site that could assist the CADD process. Furthermore, MD simulations 
may be performed on this dynamic system to find any targetable transient pockets on this domain [359-361].

4. Targeting ER-NTD: The NTD houses the important AF1 pocket that can result in hormone-independent transcriptional function of the ER. Targeting this pocket could help in total inhibition of ER activity. Since the region is highly elusive due to it intrinsically disordered nature in all of the SHRs, more structural biology efforts are needed to reveal structural details about the ER-NTD in order to define the small molecule binding pocket for rational SBDD. The combined use of FRAGFOLD-IDP and IDP-LZerD algorithm could be used to model these disordered stretches $[47,48]$. Once a viable structure has been predicted, binding site prediction and virtual screening could be employed in discovery of small molecule inhibitors that could target this site. However, in vitro and in vivo tests would still be necessary to prove the experimental value of these inhibitors. Given the uncertainty and the lack of viable structures of this domain, targeting the F-domain, as discussed above, would provide a more concrete strategy in inhibition of AF1 transcription.

5. Targeting ER $\alpha$ via selective dimerization inducers: This induced protein-protein interaction could be a promising approach for selective inhibition of ER $\alpha$ but more work needs to be done in this aspect. Since it is unclear how cosmosiin and angolesin induce selective dimerization of $E R$, to find potential novel molecules with the same nature, similarity search on these known compounds could be employed using tools such as ROCS (OpenEye) [362].

A drug discovery pipeline includes in silico screening along with in vitro and in vivo experiments for a balance between speed and quality [363]. As computational power and resources increase dramatically, the intelligent use of various CADD techniques that are already readily available to the scientific community should effectively accelerate ER-directed drug discovery.

In particular, the development of Deep-learning accelerated docking enables the virtual screening of billion compounds in ZINC 15 compound library thereby greatly expanding the chemical space that can now be explored [348]. Following the Best Practices of CADD, we have conducted extensive and rigorous research for discovery of target novel inhibitors on AF2 [350], BF3 [325,351,352] and DBD (both P-box [353,354] and D-box [355]) binding sites in AR as an alternative strategy to a similar conventional Androgen binding site driven inhibition for the same $[38,363]$. We have found potent inhibitors using computationally driven drug design pipelines and similar strategies can be applied to further development in small molecule inhibitors of ER $\alpha$ [38,363]. In fact, as discussed in Section 3.2, Kriti et al. used these practices in discovery of novel potent compounds against ER-AF2 [297,300]. Significant computational resources could be used to further explore and observe the effects of ER mutation and resistance and for drug discovery for these mutated proteins. In general, the rise of deep learning and artificial intelligence results in a newfound interest in approaching drug designing using novel CADD methodologies and is only set to increase in the coming years. However, it should always be kept in the focus that any in silico approach is not free from its own shortcomings, thus there will always be a need for high-quality in vivo and in vitro data, essential for creating any sound drug design pipeline.

Author Contributions: D.B. conceived and wrote the original manuscript, revised and finalized the manuscript. F.B., P.S.R., K.S. and A.C. provided supervision, reviewed and edited the original manuscript. All authors provided feedback. All authors have read and agreed to the published version of the manuscript.

Funding: Research was partially supported by Canadian Cancer Society Grant \#706145.

Conflicts of Interest: The authors declare no conflict of interest. 


\section{Abbreviations}

\begin{tabular}{|c|c|}
\hline $\mathrm{BCa}$ & Breast cancer \\
\hline ER & Estrogen Receptor \\
\hline EU & European Union \\
\hline PR & Progesterone Receptor \\
\hline HER2 & Human epidermal growth factor 2 \\
\hline HR & Hormone receptor \\
\hline SERM & Selective estrogen receptor modulator \\
\hline SERD & Selective estrogen receptor degrader \\
\hline HT & Hormone therapy \\
\hline AI & Aromatic inhibitors \\
\hline HTS & High throughput screening \\
\hline CADD & Computer-aided drug design \\
\hline SBDD & Structure based drug design \\
\hline IDP & Intrinsically disordered proteins \\
\hline MD & Molecular dynamics \\
\hline SAR & Structure-activity relationship \\
\hline EPA & Environmental protection agency \\
\hline $\mathrm{TF}$ & Transcription factor \\
\hline SHR & Steroid Hormone receptor \\
\hline AR & Androgen receptor \\
\hline GR & Glucocorticoid receptor \\
\hline MR & Mineralocorticoid receptor \\
\hline NTD & N-terminal domain \\
\hline DBD & DNA binding domain \\
\hline LBD & Ligand binding domain \\
\hline AF1 & Activation function-1 \\
\hline ERE & Estrogen response element \\
\hline AF2 & Activation function-2 \\
\hline EBS & Estrogen binding site \\
\hline E1 & Estrone \\
\hline E2 & $17 \beta$-Estradiol \\
\hline E3 & Estriol \\
\hline E4 & Esterol \\
\hline $\mathrm{OHT}$ & 4-hydroxy-tamoxifen \\
\hline VS & Virtual screening \\
\hline PLIF & protein-ligand interaction fingerprints \\
\hline Tc & Tanimoto coefficient \\
\hline DUD & directory of useful decoys \\
\hline FP & Fluorescence polarization \\
\hline DUD-E & DUD enhanced \\
\hline PROTAC & Proteolysis-targeting chimeras \\
\hline VHL & Von Hippel-Lindau \\
\hline SNIPERs & Specific and nongenetic IAPs-dependent protein erasers \\
\hline cIAP1 & Cellular inhibitor of apoptosis protein 1 \\
\hline TD & N-terminal aspartic acid cross linking \\
\hline TD-PERM & TD peptidomimetic ER modulator \\
\hline SERCA & Selective ER covalent antagonist \\
\hline ERX-11 & ER co-regulator binding modulator- 11 \\
\hline FAA & Fluorescence anistropy assay \\
\hline TR-FRET & Time-resolved fluorescence resonance energy transfer \\
\hline $\mathrm{M} 2 \mathrm{H}$ & Mammalian two-hybrid \\
\hline
\end{tabular}




$\begin{array}{ll}\text { DIBA } & \text { 2,2'- dithiobisbenzamidine } \\ \text { BITA } & \text { Benzisothiazolone } \\ \text { 15d-PGJ2 } & \text { 15-Deoxy-Delta-12,14-prostaglandin J2 } \\ \text { TPBM } & \text { 8-benzylsulfanylmethyl-1,3-dimethyl-3,7-dihydropurine-2,6-dione } \\ \text { AA } & \text { Anacardic acid } \\ \text { BRET } & \text { bioluminescence resonance energy transfer } \\ \text { BF3 } & \text { Binding function -3 } \\ \text { EF } & \text { Enrichment factor } \\ \text { DEKOIS } & \text { demanding evaluation kits for in silico screening } \\ \text { VDS } & \text { Virtual decoy set } \\ \text { AUC } & \text { Area under the receiver operating characteristic curve } \\ \text { ToxCast } & \text { Toxicity ForeCaster } \\ \text { Tox21 } & \text { Toxicology Testing in the 21st Century collaboration } \\ \text { CERAPP } & \text { Collaborative ER Activity Prediction Project }\end{array}$

\section{References}

1. Ferlay, J.; Shin, H.R.; Bray, F.; Forman, D.; Mathers, C.; Parkin, D.M. Estimates of worldwide burden of cancer in 2008: GLOBOCAN 2008. Int. J. Cancer 2010, 127, 2893-2917. [CrossRef]

2. Siegel, R.L.; Miller, K.D.; Jemal, A. Cancer statistics, 2020. CA: Cancer J. Clin. 2020, 70, 7-30. [CrossRef]

3. Siegel, R.L.; Miller, K.D.; Jemal, A. Cancer statistics, 2019. CA: Cancer J. Clin. 2019, 69, 7-34. [CrossRef]

4. Harbeck, N.; Penault-Llorca, F.; Cortes, J.; Gnant, M.; Houssami, N.; Poortmans, P.; Ruddy, K.; Tsang, J.; Cardoso, F. Breast cancer. Nat. Rev. Dis. Primers 2019, 5, 66. [CrossRef] [PubMed]

5. Ross, J.S.; Slodkowska, E.A.; Symmans, W.F.; Pusztai, L.; Ravdin, P.M.; Hortobagyi, G.N. The HER-2 receptor and breast cancer: Ten years of targeted anti-HER-2 therapy and personalized medicine. Oncologist 2009, 14, 320-368. [CrossRef] [PubMed]

6. Mitri, Z.; Constantine, T.; O'Regan, R. The HER2 Receptor in Breast Cancer: Pathophysiology, Clinical Use, and New Advances in Therapy. Chemother. Res. Pr. 2012, 2012, 743193. [CrossRef] [PubMed]

7. Fragomeni, S.M.; Sciallis, A.; Jeruss, J.S. Molecular Subtypes and Local-Regional Control of Breast Cancer. Surg. Oncol. Clin. 2018, 27, 95-120. [CrossRef]

8. Cameron, D.; Piccart-Gebhart, M.J.; Gelber, R.D.; Procter, M.; Goldhirsch, A.; de Azambuja, E.; Castro, G., Jr.; Untch, M.; Smith, I.; Gianni, L. 11 years' follow-up of trastuzumab after adjuvant chemotherapy in HER2-positive early breast cancer: Final analysis of the HERceptin Adjuvant (HERA) trial. Lancet 2017, 389, 1195-1205. [CrossRef]

9. Ostrow, S.; Egorin, M.; Aisner, J.; Bachur, N.; Wiernik, P. High-dose cis-diamminedichloro-platinum therapy in patients with advanced breast cancer: Pharmacokinetics, toxicity, and therapeutic efficacy. Cancer Clin. Trials 1980, 3, 23-27.

10. Hill, D.P.; Harper, A.; Malcolm, J.; McAndrews, M.S.; Mockus, S.M.; Patterson, S.E.; Reynolds, T.; Baker, E.J.; Bult, C.J.; Chesler, E.J. Cisplatin-resistant triple-negative breast cancer subtypes: Multiple mechanisms of resistance. BMC Cancer 2019, 19, 1039. [CrossRef]

11. Scholzen, T.; Gerdes, J. The Ki-67 protein: From the known and the unknown. J. Cell. Physiol. 2000, 182, 311-322. [CrossRef]

12. Yerushalmi, R.; Woods, R.; Ravdin, P.M.; Hayes, M.M.; Gelmon, K.A. Ki67 in breast cancer: Prognostic and predictive potential. Lancet Oncol. 2010, 11, 174-183. [CrossRef]

13. Li, C.I.; Uribe, D.J.; Daling, J.R. Clinical characteristics of different histologic types of breast cancer. Br. J. Cancer 2005, 93, 1046-1052. [CrossRef] [PubMed]

14. Harbeck, N.; Gnant, M. Breast cancer. Lancet 2017, 389, 1134-1150. [CrossRef]

15. Waks, A.G.; Winer, E.P. Breast Cancer Treatment: A Review. JAMA 2019, 321, 288-300. [CrossRef]

16. Grodin, J.; Siiteri, P.; MacDonald, P. Source of estrogen production in postmenopausal women. J. Clin. Endocrinol. Metab. 1973, 36, 207-214. [CrossRef]

17. Heldring, N.; Pike, A.; Andersson, S.; Matthews, J.; Cheng, G.; Hartman, J.; Tujague, M.; Strom, A.; Treuter, E.; Warner, M.; et al. Estrogen receptors: How do they signal and what are their targets. Physiol. Rev. 2007, 87, 905-931. [CrossRef] 
18. Lipovka, Y.; Konhilas, J.P. The complex nature of oestrogen signalling in breast cancer: Enemy or ally? Biosci. Rep. 2016, 36. [CrossRef]

19. Harvey, J.M.; Clark, G.M.; Osborne, C.K.; Allred, D.C. Estrogen receptor status by immunohistochemistry is superior to the ligand-binding assay for predicting response to adjuvant endocrine therapy in breast cancer. J. Clin. Oncol. 1999, 17, 1474-1481. [CrossRef]

20. Althuis, M.D.; Fergenbaum, J.H.; Garcia-Closas, M.; Brinton, L.A.; Madigan, M.P.; Sherman, M.E. Etiology of hormone receptor-defined breast cancer: A systematic review of the literature. Cancer Epidemiol. Prev. Biomark. 2004, 13, 1558-1568.

21. Burstein, H.J.; Griggs, J.J.; Prestrud, A.A.; Temin, S. American society of clinical oncology clinical practice guideline update on adjuvant endocrine therapy for women with hormone receptor-positive breast cancer. J. Oncol. Pr. 2010, 6, 243-246. [CrossRef] [PubMed]

22. Burstein, H.J.; Lacchetti, C.; Anderson, H.; Buchholz, T.A.; Davidson, N.E.; Gelmon, K.A.; Giordano, S.H.; Hudis, C.A.; Solky, A.J.; Stearns, V.; et al. Adjuvant Endocrine Therapy for Women with Hormone Receptor-Positive Breast Cancer: ASCO Clinical Practice Guideline Focused Update. J. Clin. Oncol. 2019, 37, 423-438. [CrossRef] [PubMed]

23. Burstein, H.J.; Temin, S.; Anderson, H.; Buchholz, T.A.; Davidson, N.E.; Gelmon, K.E.; Giordano, S.H.; Hudis, C.A.; Rowden, D.; Solky, A.J.; et al. Adjuvant endocrine therapy for women with hormone receptor-positive breast cancer: American society of clinical oncology clinical practice guideline focused update. J. Clin. Oncol. 2014, 32, 2255-2269. [CrossRef] [PubMed]

24. Tremont, A.; Lu, J.; Cole, J.T. Endocrine Therapy for Early Breast Cancer: Updated Review. Ochsner J. 2017, 17, 405-411. [PubMed]

25. Wazir, U.; Mokbel, L.; Wazir, A.; Mokbel, K. Optimizing adjuvant endocrine therapy for early ER+ breast cancer: An update for surgeons. Am. J. Surg. 2019, 217, 152-155. [CrossRef] [PubMed]

26. Awan, A.; Esfahani, K. Endocrine therapy for breast cancer in the primary care setting. Curr. Oncol. 2018, 25, 285-291. [CrossRef]

27. Arnedos, M.; Vicier, C.; Loi, S.; Lefebvre, C.; Michiels, S.; Bonnefoi, H.; Andre, F. Precision medicine for metastatic breast cancer-limitations and solutions. Nat. Rev. Clin. Oncol. 2015, 12, 693-704. [CrossRef]

28. Hare, S.H.; Harvey, A.J. mTOR function and therapeutic targeting in breast cancer. Am. J. Cancer Res. 2017, 7, 383-404.

29. Steelman, L.S.; Martelli, A.M.; Cocco, L.; Libra, M.; Nicoletti, F.; Abrams, S.L.; McCubrey, J.A. The therapeutic potential of mTOR inhibitors in breast cancer. Br. J. Clin. Pharm. 2016, 82, 1189-1212. [CrossRef]

30. Fasolo, A.; Sessa, C. mTOR inhibitors in the treatment of cancer. Expert Opin. Investig. Drugs 2008, 17, 1717-1734. [CrossRef]

31. Guo, Q.; Lin, X.; Ye, L.; Xu, R.; Dai, Y.; Zhang, Y.; Chen, Q. Comparative Efficacy of CDK4/6 Inhibitors Plus Aromatase Inhibitors Versus Fulvestrant for the First-Line Treatment of Hormone Receptor-Positive Advanced Breast Cancer: A Network Meta-Analysis. Target. Oncol. 2019, 14, 139-148. [CrossRef]

32. Pernas, S.; Tolaney, S.M.; Winer, E.P.; Goel, S. CDK4/6 inhibition in breast cancer: Current practice and future directions. Adv. Med. Oncol. 2018, 10. [CrossRef] [PubMed]

33. Spring, L.M.; Wander, S.A.; Zangardi, M.; Bardia, A. CDK 4/6 Inhibitors in Breast Cancer: Current Controversies and Future Directions. Curr. Oncol. Rep. 2019, 21, 25. [CrossRef] [PubMed]

34. Portman, N.; Alexandrou, S.; Carson, E.; Wang, S.; Lim, E.; Caldon, C.E. Overcoming CDK4/6 inhibitor resistance in ER positive breast cancer. Endocr. Relat. Cancer 2018. [CrossRef] [PubMed]

35. Siersbaek, R.; Kumar, S.; Carroll, J.S. Signaling pathways and steroid receptors modulating estrogen receptor alpha function in breast cancer. Genes Dev. 2018, 32, 1141-1154. [CrossRef]

36. McDonnell, D.P.; Wardell, S.E.; Norris, J.D. Oral Selective Estrogen Receptor Downregulators (SERDs), a Breakthrough Endocrine Therapy for Breast Cancer. J. Med. Chem. 2015, 58, 4883-4887. [CrossRef]

37. Hultsch, S.; Kankainen, M.; Paavolainen, L.; Kovanen, R.M.; Ikonen, E.; Kangaspeska, S.; Pietiainen, V.; Kallioniemi, O. Association of tamoxifen resistance and lipid reprogramming in breast cancer. BMC Cancer 2018, 18, 850. [CrossRef]

38. Ban, F.; Dalal, K.; Li, H.; LeBlanc, E.; Rennie, P.S.; Cherkasov, A. Best Practices of Computer-Aided Drug Discovery: Lessons Learned from the Development of a Preclinical Candidate for Prostate Cancer with a New Mechanism of Action. J. Chem. Inf. Model. 2017, 57, 1018-1028. [CrossRef]

39. Wade, R.C.; Salo-Ahen, O.M. Molecular modeling in drug design. Molecules 2019, 24, 321. [CrossRef] 
40. Simulations Plus. Available online: https://www.simulations-plus.com/ (accessed on 28 April 2020).

41. Okumu, A.; DiMaso, M.; Löbenberg, R. Computer simulations using GastroPlus ${ }^{\mathrm{TM}}$ to justify a biowaiver for etoricoxib solid oral drug products. Eur. J. Pharm. Biopharm. 2009, 72, 91-98. [CrossRef]

42. Chemical Computing Group Inc. Molecular Operating Environment (MOE); Chemical Computing Group Inc. 1010 Sherbooke St. West, Suite\# 910: Montreal, QC, Canada, 2016.

43. Friesner, R.A.; Murphy, R.B.; Repasky, M.P.; Frye, L.L.; Greenwood, J.R.; Halgren, T.A.; Sanschagrin, P.C.; Mainz, D.T. Extra precision glide: Docking and scoring incorporating a model of hydrophobic enclosure for protein-ligand complexes. J. Med. Chem. 2006, 49, 6177-6196. [CrossRef] [PubMed]

44. Van Der Spoel, D.; Lindahl, E.; Hess, B.; Groenhof, G.; Mark, A.E.; Berendsen, H.J. GROMACS: Fast, flexible, and free. J. Comput. Chem. 2005, 26, 1701-1718. [CrossRef] [PubMed]

45. Webb, B.; Sali, A. Comparative protein structure modeling using MODELLER. Curr. Protoc. Bioinform. 2014, 47, 5.6.1-5.6.32. [CrossRef] [PubMed]

46. Yang, J.; Yan, R.; Roy, A.; Xu, D.; Poisson, J.; Zhang, Y. The I-TASSER Suite: Protein structure and function prediction. Nat. Methods 2015, 12, 7. [CrossRef]

47. Kosciolek, T.; Buchan, D.W.; Jones, D.T. Predictions of backbone dynamics in intrinsically disordered proteins using de novo fragment-based protein structure predictions. Sci. Rep. 2017, 7, 1-12. [CrossRef]

48. Peterson, L.X.; Roy, A.; Christoffer, C.; Terashi, G.; Kihara, D. Modeling disordered protein interactions from biophysical principles. PLoS Comput. Biol. 2017, 13, e1005485. [CrossRef]

49. Hollingsworth, S.A.; Dror, R.O. Molecular dynamics simulation for all. Neuron 2018, 99, 1129-1143. [CrossRef]

50. Brady, G.P.; Stouten, P.F. Fast prediction and visualization of protein binding pockets with PASS. J. Comput. Aided Mol. Des. 2000, 14, 383-401. [CrossRef]

51. Laurie, A.T.; Jackson, R.M. Q-SiteFinder: An energy-based method for the prediction of protein-ligand binding sites. Bioinformatics 2005, 21, 1908-1916. [CrossRef]

52. Ferreira, L.G.; Dos Santos, R.N.; Oliva, G.; Andricopulo, A.D. Molecular docking and structure-based drug design strategies. Molecules 2015, 20, 13384-13421. [CrossRef]

53. Abagyan, R.; Totrov, M.; Kuznetsov, D. ICM-A new method for protein modeling and design: Applications to docking and structure prediction from the distorted native conformation. J. Comput. Chem. 1994, 15, 488-506. [CrossRef]

54. Trott, O.; Olson, A.J. AutoDock Vina: Improving the speed and accuracy of docking with a new scoring function, efficient optimization, and multithreading. J. Comput. Chem. 2010, 31, 455-461. [CrossRef] [PubMed]

55. Cherkasov, A.; Muratov, E.N.; Fourches, D.; Varnek, A.; Baskin, I.I.; Cronin, M.; Dearden, J.; Gramatica, P.; Martin, Y.C.; Todeschini, R. QSAR modeling: Where have you been? Where are you going to? J. Med. Chem. 2014, 57, 4977-5010. [CrossRef] [PubMed]

56. Neves, B.J.; Braga, R.C.; Melo-Filho, C.C.; Moreira-Filho, J.T.; Muratov, E.N.; Andrade, C.H. QSAR-based virtual screening: Advances and applications in drug discovery. Front. Pharmacol. 2018, 9, 1275. [CrossRef] [PubMed]

57. Tanrikulu, Y.; Schneider, G. Pseudoreceptor models in drug design: Bridging ligand-and receptor-based virtual screening. Nat. Rev. Drug Discov. 2008, 7, 667-677. [CrossRef] [PubMed]

58. Vedani, A.; Dobler, M.; Lill, M. Combining Protein Modeling and 6D-QSAR. Simulating the Binding of Structurally Diverse Ligands to the Estrogen Receptor. J. Med. Chem. 2005, 48, 3700-3703. [CrossRef]

59. Lloyd, D.G.; Buenemann, C.L.; Todorov, N.P.; Manallack, D.T.; Dean, P.M. Scaffold hopping in de novo design. Ligand generation in the absence of receptor information. J. Med. Chem. 2004, 47, 493-496. [CrossRef]

60. Hua, H.; Zhang, H.; Kong, Q.; Jiang, Y. Mechanisms for estrogen receptor expression in human cancer. Exp. Hematol. Oncol. 2018, 7, 1-11. [CrossRef]

61. Thomas, C.; Gustafsson, J.-Å. The different roles of ER subtypes in cancer biology and therapy. Nat. Rev. Cancer 2011, 11, 597-608. [CrossRef]

62. Holst, F.; Stahl, P.R.; Ruiz, C.; Hellwinkel, O.; Jehan, Z.; Wendland, M.; Lebeau, A.; Terracciano, L.; Al-Kuraya, K.; Jänicke, F. Estrogen receptor alpha (ESR1) gene amplification is frequent in breast cancer. Nat. Genet. 2007, 39, 655-660. [CrossRef]

63. Yu, K.-D.; Shao, Z.-M. ESR1 gene amplification: Another mechanism regulating the cellular levels of ER $\alpha$. Nat. Rev. Cancer 2011, 11, 823. [CrossRef] [PubMed] 
64. Benevolenskaya, E.V.; Islam, A.B.; Ahsan, H.; Kibriya, M.G.; Jasmine, F.; Wolff, B.; Al-Alem, U.; Wiley, E.; Kajdacsy-Balla, A.; Macias, V. DNA methylation and hormone receptor status in breast cancer. Clin. Epigenet. 2016, 8, 17. [CrossRef] [PubMed]

65. Yan, L.; Nass, S.J.; Smith, D.; Nelson, W.G.; Herman, J.G.; Davidson, N.E. Specific inhibition of DNMT1 by antisense oligonucleotides induces re-expression of estrogen receptor a (ER) in ER-negative human breast cancer cell lines. Cancer Biol. Ther. 2003, 2, 552-556. [CrossRef] [PubMed]

66. Stark, K.; Burger, A.; Wu, J.; Shelton, P.; Polin, L.; Li, J. Reactivation of estrogen receptor alpha by vorinostat sensitizes mesenchymal-like triple-negative breast cancer to aminoflavone, a ligand of the aryl hydrocarbon receptor. PLoS ONE 2013, 8, e74525. [CrossRef]

67. Pike, A.C.W.; Brzozowski, A.M.; Hubbard, R.E. A structural biologist's view of the oestrogen receptor. J. Steroid Biochem. Mol. Biol. 2000, 74, 261-268. [CrossRef]

68. Strom, A.; Hartman, J.; Foster, J.S.; Kietz, S.; Wimalasena, J.; Gustafsson, J.A. Estrogen receptor beta inhibits 17beta-estradiol-stimulated proliferation of the breast cancer cell line T47D. Proc. Natl. Acad. Sci. USA 2004, 101, 1566-1571. [CrossRef] [PubMed]

69. Lazennec, G.; Bresson, D.; Lucas, A.; Chauveau, C.; Vignon, F. ER beta inhibits proliferation and invasion of breast cancer cells. Endocrinology 2001, 142, 4120-4130. [CrossRef] [PubMed]

70. Helguero, L.A.; Faulds, M.H.; Gustafsson, J.A.; Haldosen, L.A. Estrogen receptors alfa (ERalpha) and beta (ERbeta) differentially regulate proliferation and apoptosis of the normal murine mammary epithelial cell line HC11. Oncogene 2005, 24, 6605-6616. [CrossRef] [PubMed]

71. Hayashi, S.I.; Eguchi, H.; Tanimoto, K.; Yoshida, T.; Omoto, Y.; Inoue, A.; Yoshida, N.; Yamaguchi, Y. The expression and function of estrogen receptor alpha and beta in human breast cancer and its clinical application. Endocr. Relat. Cancer 2003, 10, 193-202. [CrossRef]

72. Warnmark, A.; Wikstrom, A.; Wright, A.P.; Gustafsson, J.A.; Hard, T. The N-terminal regions of estrogen receptor alpha and beta are unstructured in vitro and show different TBP binding properties. J. Biol. Chem. 2001, 276, 45939-45944. [CrossRef]

73. Lavery, D.N.; McEwan, I.J. Structure and function of steroid receptor AF1 transactivation domains: Induction of active conformations. Biochem. J. 2005, 391, 449-464. [CrossRef]

74. Chen, D.; Riedl, T.; Washbrook, E.; Pace, P.E.; Coombes, R.C.; Egly, J.M.; Ali, S. Activation of estrogen receptor alpha by S118 phosphorylation involves a ligand-dependent interaction with TFIIH and participation of CDK7. Mol. Cell 2000, 6, 127-137. [CrossRef]

75. Dutertre, M.; Smith, C.L. Ligand-independent interactions of p160/steroid receptor coactivators and CREB-binding protein (CBP) with estrogen receptor-alpha: Regulation by phosphorylation sites in the A/B region depends on other receptor domains. Mol. Endocrinol. 2003, 17, 1296-1314. [CrossRef]

76. Tremblay, A.; Tremblay, G.B.; Labrie, F.; Giguere, V. Ligand-independent recruitment of SRC-1 to estrogen receptor beta through phosphorylation of activation function AF-1. Mol. Cell 1999, 3, 513-519. [CrossRef]

77. Simons, S.S., Jr.; Edwards, D.P.; Kumar, R. Minireview: Dynamic structures of nuclear hormone receptors: New promises and challenges. Mol. Endocrinol. 2014, 28, 173-182. [CrossRef]

78. Zwart, W.; de Leeuw, R.; Rondaij, M.; Neefjes, J.; Mancini, M.A.; Michalides, R. The hinge region of the human estrogen receptor determines functional synergy between AF-1 and AF-2 in the quantitative response to estradiol and tamoxifen. J. Cell Sci. 2010, 123, 1253-1261. [CrossRef] [PubMed]

79. Ruff, M.; Gangloff, M.; Wurtz, J.M.; Moras, D. Estrogen receptor transcription and transactivation: Structure-function relationship in DNA- and ligand-binding domains of estrogen receptors. Breast Cancer Res. 2000, 2, 353-359. [CrossRef] [PubMed]

80. Kuntz, M.A.; Shapiro, D.J. Dimerizing the estrogen receptor DNA binding domain enhances binding to estrogen response elements. J. Biol. Chem. 1997, 272, 27949-27956. [CrossRef]

81. Aagaard, M.M.; Siersbaek, R.; Mandrup, S. Molecular basis for gene-specific transactivation by nuclear receptors. Biochim. Biophys. Acta 2011, 1812, 824-835. [CrossRef] [PubMed]

82. Schwabe, J.W.; Chapman, L.; Finch, J.T.; Rhodes, D. The crystal structure of the estrogen receptor DNA-binding domain bound to DNA: How receptors discriminate between their response elements. Cell 1993, 75, 567-578. [CrossRef]

83. Schwabe, J.W.; Chapman, L.; Finch, J.T.; Rhodes, D.; Neuhaus, D. DNA recognition by the oestrogen receptor: From solution to the crystal. Structure 1993, 1, 187-204. [CrossRef] 
84. Burns, K.A.; Li, Y.; Arao, Y.; Petrovich, R.M.; Korach, K.S. Selective mutations in estrogen receptor alpha D-domain alters nuclear translocation and non-estrogen response element gene regulatory mechanisms. J. Biol. Chem. 2011, 286, 12640-12649. [CrossRef] [PubMed]

85. Zhang, Y.; Li, Z.; Sacks, D.B.; Ames, J.B. Structural basis for Ca2+-induced activation and dimerization of estrogen receptor $\alpha$ by calmodulin. J. Biol. Chem. 2012, 287, 9336-9344. [CrossRef]

86. Subramanian, K.; Jia, D.; Kapoor-Vazirani, P.; Powell, D.R.; Collins, R.E.; Sharma, D.; Peng, J.; Cheng, X.; Vertino, P.M. Regulation of estrogen receptor $\alpha$ by the SET7 lysine methyltransferase. Mol. Cell 2008, 30, 336-347. [CrossRef] [PubMed]

87. Jiang, Y.; Trescott, L.; Holcomb, J.; Zhang, X.; Brunzelle, J.; Sirinupong, N.; Shi, X.; Yang, Z. Structural insights into estrogen receptor $\alpha$ methylation by histone methyltransferase SMYD2, a cellular event implicated in estrogen signaling regulation. J. Mol. Biol. 2014, 426, 3413-3425. [CrossRef] [PubMed]

88. Kumar, R.; Zakharov, M.N.; Khan, S.H.; Miki, R.; Jang, H.; Toraldo, G.; Singh, R.; Bhasin, S.; Jasuja, R. The dynamic structure of the estrogen receptor. J. Amino Acids 2011, 2011, 812540. [CrossRef]

89. Gangloff, M.; Ruff, M.; Eiler, S.; Duclaud, S.; Wurtz, J.M.; Moras, D. Crystal structure of a mutant hERalpha ligand-binding domain reveals key structural features for the mechanism of partial agonism. J. Biol. Chem. 2001, 276, 15059-15065. [CrossRef]

90. Fanning, S.W.; Mayne, C.G.; Dharmarajan, V.; Carlson, K.E.; Martin, T.A.; Novick, S.J.; Toy, W.; Green, B.; Panchamukhi, S.; Katzenellenbogen, B.S.; et al. Estrogen receptor alpha somatic mutations Y537S and D538G confer breast cancer endocrine resistance by stabilizing the activating function-2 binding conformation. Elife 2016, 5. [CrossRef]

91. Pike, A.C.W.; Brzozowski, A.M.; Hubbard, R.E.; Bonn, T.; Thorsell, A.G.; Engstrom, O.; Ljunggren, J.; Gustafsson, J.K.; Carlquist, M. Structure of the ligand-binding domain of oestrogen receptor beta in the presence of a partial agonist and a full antagonist. EMBO J. 1999, 18, 4608-4618. [CrossRef]

92. Brzozowski, A.M.; Pike, A.C.; Dauter, Z.; Hubbard, R.E.; Bonn, T.; Engstrom, O.; Ohman, L.; Greene, G.L.; Gustafsson, J.A.; Carlquist, M. Molecular basis of agonism and antagonism in the oestrogen receptor. Nature 1997, 389, 753-758. [CrossRef] [PubMed]

93. Jackson, T.A.; Richer, J.K.; Bain, D.L.; Takimoto, G.S.; Tung, L.; Horwitz, K.B. The partial agonist activity of antagonist-occupied steroid receptors is controlled by a novel hinge domain-binding coactivator L7/SPA and the corepressors N-CoR or SMRT. Mol. Endocrinol. 1997, 11, 693-705. [CrossRef] [PubMed]

94. Hewitt, S.C.; Korach, K.S. Estrogen Receptors: New Directions in the New Millennium. Endocr. Rev. 2018, 39, 664-675. [CrossRef] [PubMed]

95. Bjornstrom, L.; Sjoberg, M. Mechanisms of estrogen receptor signaling: Convergence of genomic and nongenomic actions on target genes. Mol. Endocrinol. 2005, 19, 833-842. [CrossRef] [PubMed]

96. Arao, Y.; Korach, K.S. The F domain of estrogen receptor alpha is involved in species-specific, tamoxifen-mediated transactivation. J. Biol. Chem. 2018, 293, 8495-8507. [CrossRef]

97. Montano, M.M.; Muller, V.; Trobaugh, A.; Katzenellenbogen, B.S. The carboxy-terminal F domain of the human estrogen receptor: Role in the transcriptional activity of the receptor and the effectiveness of antiestrogens as estrogen antagonists. Mol. Endocrinol. 1995, 9, 814-825. [CrossRef]

98. Yang, J.; Singleton, D.W.; Shaughnessy, E.A.; Khan, S.A. The F-domain of estrogen receptor-alpha inhibits ligand induced receptor dimerization. Mol. Cell. Endocrinol. 2008, 295, 94-100. [CrossRef]

99. De Vries-van Leeuwen, I.J.; da Costa Pereira, D.; Flach, K.D.; Piersma, S.R.; Haase, C.; Bier, D.; Yalcin, Z.; Michalides, R.; Feenstra, K.A.; Jimenez, C.R.; et al. Interaction of 14-3-3 proteins with the estrogen receptor alpha F domain provides a drug target interface. Proc. Natl. Acad. Sci. USA 2013, 110, 8894-8899. [CrossRef]

100. Sijbesma, E.; Hallenbeck, K.K.; Leysen, S.; de Vink, P.J.; Skóra, L.; Jahnke, W.; Brunsveld, L.; Arkin, M.R.; Ottmann, C. Site-Directed Fragment-Based Screening for the Discovery of Protein-Protein Interaction Stabilizers. J. Am. Chem. Soc. 2019, 141, 3524-3531. [CrossRef]

101. Chantalat, E.; Boudou, F.; Laurell, H.; Palierne, G.; Houtman, R.; Melchers, D.; Rochaix, P.; Filleron, T.; Stella, A.; Burlet-Schiltz, O; et al. The AF-1-deficient estrogen receptor ERalpha46 isoform is frequently expressed in human breast tumors. Breast Cancer Res. 2016, 18, 123. [CrossRef]

102. Flouriot, G.; Brand, H.; Denger, S.; Metivier, R.; Kos, M.; Reid, G.; Sonntag-Buck, V.; Gannon, F. Identification of a new isoform of the human estrogen receptor-alpha (hER-alpha) that is encoded by distinct transcripts and that is able to repress hER-alpha activation function 1. EMBO J. 2000, 19, 4688-4700. [CrossRef] 
103. Marquez, D.C.; Pietras, R.J. Membrane-associated binding sites for estrogen contribute to growth regulation of human breast cancer cells. Oncogene 2001, 20,5420-5430. [CrossRef] [PubMed]

104. Chaudhri, R.A.; Hadadi, A.; Lobachev, K.S.; Schwartz, Z.; Boyan, B.D. Estrogen receptor-alpha 36 mediates the anti-apoptotic effect of estradiol in triple negative breast cancer cells via a membrane-associated mechanism. Biochim. Biophys. Acta 2014, 1843, 2796-2806. [CrossRef] [PubMed]

105. Chaudhri, R.A.; Olivares-Navarrete, R.; Cuenca, N.; Hadadi, A.; Boyan, B.D.; Schwartz, Z. Membrane estrogen signaling enhances tumorigenesis and metastatic potential of breast cancer cells via estrogen receptor-alpha36 (ERalpha36). J. Biol. Chem. 2012, 287, 7169-7181. [CrossRef] [PubMed]

106. Deng, H.; Zhang, X.T.; Wang, M.L.; Zheng, H.Y.; Liu, L.J.; Wang, Z.Y. ER-alpha36-mediated rapid estrogen signaling positively regulates ER-positive breast cancer stem/progenitor cells. PLoS ONE 2014, 9, e88034. [CrossRef]

107. Shi, L.; Dong, B.; Li, Z.; Lu, Y.; Ouyang, T.; Li, J.; Wang, T.; Fan, Z.; Fan, T.; Lin, B.; et al. Expression of ER-\{alpha\}36, a novel variant of estrogen receptor $\{$ alpha\}, and resistance to tamoxifen treatment in breast cancer. J. Clin. Oncol. 2009, 27, 3423-3429. [CrossRef]

108. Erenburg, I.; Schachter, B.; Mira y Lopez, R.; Ossowski, L. Loss of an estrogen receptor isoform (ER alpha delta 3 ) in breast cancer and the consequences of its reexpression: Interference with estrogen-stimulated properties of malignant transformation. Mol. Endocrinol. 1997, 11, 2004-2015. [CrossRef]

109. Thomas, C.; Gustafsson, J.A. Estrogen receptor mutations and functional consequences for breast cancer. Trends Endocrinol. Metab. 2015, 26, 467-476. [CrossRef]

110. Shah, S.P.; Roth, A.; Goya, R.; Oloumi, A.; Ha, G.; Zhao, Y.; Turashvili, G.; Ding, J.; Tse, K.; Haffari, G.; et al. The clonal and mutational evolution spectrum of primary triple-negative breast cancers. Nature 2012, 486, 395-399. [CrossRef]

111. Oesterreich, S.; Davidson, N.E. The search for ESR1 mutations in breast cancer. Nat. Genet. 2013, 45, 1415-1416. [CrossRef]

112. Toy, W.; Shen, Y.; Won, H.; Green, B.; Sakr, R.A.; Will, M.; Li, Z.; Gala, K.; Fanning, S.; King, T.A. ESR1 ligand-binding domain mutations in hormone-resistant breast cancer. Nat. Genet. 2013, 45, 1439. [CrossRef]

113. Robinson, D.R.; Wu, Y.-M.; Vats, P.; Su, F.; Lonigro, R.J.; Cao, X.; Kalyana-Sundaram, S.; Wang, R.; Ning, Y.; Hodges, L. Activating ESR1 mutations in hormone-resistant metastatic breast cancer. Nat. Genet. 2013, 45, 1446. [CrossRef] [PubMed]

114. Jeselsohn, R.; Yelensky, R.; Buchwalter, G.; Frampton, G.; Meric-Bernstam, F.; Gonzalez-Angulo, A.M.; Ferrer-Lozano, J.; Perez-Fidalgo, J.A.; Cristofanilli, M.; Gomez, H. Emergence of constitutively active estrogen receptor- $\alpha$ mutations in pretreated advanced estrogen receptor-positive breast cancer. Clin. Cancer Res. 2014, 20, 1757-1767. [CrossRef] [PubMed]

115. Merenbakh-Lamin, K.; Ben-Baruch, N.; Yeheskel, A.; Dvir, A.; Soussan-Gutman, L.; Jeselsohn, R.; Yelensky, R.; Brown, M.; Miller, V.A.; Sarid, D. D538G mutation in estrogen receptor- $\alpha$ : A novel mechanism for acquired endocrine resistance in breast cancer. Cancer Res. 2013, 73, 6856-6864. [CrossRef] [PubMed]

116. Barakat, R.; Oakley, O.; Kim, H.; Jin, J.; Ko, C.J. Extra-gonadal sites of estrogen biosynthesis and function. BMB Rep. 2016, 49, 488-496. [CrossRef] [PubMed]

117. Simpson, E.R. Sources of estrogen and their importance. J. Steroid Biochem. Mol. Biol. 2003, 86, $225-230$. [CrossRef]

118. Menazza, S.; Murphy, E. The Expanding Complexity of Estrogen Receptor Signaling in the Cardiovascular System. Circ. Res. 2016, 118, 994-1007. [CrossRef]

119. Murphy, E. Estrogen signaling and cardiovascular disease. Circ. Res. 2011, 109, 687-696. [CrossRef]

120. Vaananen, H.K.; Harkonen, P.L. Estrogen and bone metabolism. Maturitas 1996, 23, S65-S69. [CrossRef]

121. Manolagas, S.C.; O'Brien, C.A.; Almeida, M. The role of estrogen and androgen receptors in bone health and disease. Nat. Rev. Endocrinol. 2013, 9, 699-712. [CrossRef] [PubMed]

122. Grigoriadis, S.; Seeman, M.V. The role of estrogen in schizophrenia: Implications for schizophrenia practice guidelines for women. Can. J. Psychiatry 2002, 47, 437-442. [CrossRef]

123. Nadkarni, S.; Cooper, D.; Brancaleone, V.; Bena, S.; Perretti, M. Activation of the annexin A1 pathway underlies the protective effects exerted by estrogen in polymorphonuclear leukocytes. Arter. Thromb. Vasc. Biol. 2011, 31, 2749-2759. [CrossRef] [PubMed]

124. Cui, J.; Shen, Y.; Li, R. Estrogen synthesis and signaling pathways during aging: From periphery to brain. Trends Mol. Med. 2013, 19, 197-209. [CrossRef] 
125. Liang, J.; Shang, Y. Estrogen and cancer. Annu. Rev. Physiol. 2013, 75, 225-240. [CrossRef] [PubMed]

126. Mikhael, S.; Punjala-Patel, A.; Gavrilova-Jordan, L. Hypothalamic-Pituitary-Ovarian Axis Disorders Impacting Female Fertility. Biomedicines 2019, 7, 5. [CrossRef] [PubMed]

127. Miller, W.L.; Auchus, R.J. The molecular biology, biochemistry, and physiology of human steroidogenesis and its disorders. Endocr. Rev. 2011, 32, 81-151. [CrossRef]

128. Coelingh Bennink, H.J.; Holinka, C.F.; Diczfalusy, E. Estetrol review: Profile and potential clinical applications. Climacteric 2008, 11, 47-58. [CrossRef]

129. Labhart, A. Clinical Endocrinology: Theory and Practice; Springer Science \& Business Media: Berlin, Germany, 2012.

130. Beato, M.; Herrlich, P.; Schütz, G. Steroid hormone receptors: Many actors in search of a plot. Cell 1995, 83, 851-857. [CrossRef]

131. Bourguet, W.; Ruff, M.; Chambon, P.; Gronemeyer, H.; Moras, D. Crystal structure of the ligand-binding domain of the human nuclear receptor RXR- $\alpha$. Nature 1995, 375, 377-382. [CrossRef]

132. Mangelsdorf, D.J.; Evans, R.M. The RXR heterodimers and orphan receptors. Cell 1995, 83, 841-850. [CrossRef]

133. Mangelsdorf, D.J.; Thummel, C.; Beato, M.; Herrlich, P.; Schütz, G.; Umesono, K.; Blumberg, B.; Kastner, P.; Mark, M.; Chambon, P. The nuclear receptor superfamily: The second decade. Cell 1995, 83, 835. [CrossRef]

134. Resnick, E.M.; Schreihofer, D.A.; Periasamy, A.; Shupnik, M.A. Truncated estrogen receptor product-1 suppresses estrogen receptor transactivation by dimerization with estrogen receptors $\alpha$ and $\beta$. J. Biol. Chem. 2000, 275, 7158-7166. [CrossRef] [PubMed]

135. Yasar, P.; Ayaz, G.; User, S.D.; Gupur, G.; Muyan, M. Molecular mechanism of estrogen-estrogen receptor signaling. Reprod. Med. Biol. 2017, 16, 4-20. [CrossRef]

136. Fawell, S.E.; White, R.; Hoare, S.; Sydenham, M.; Page, M.; Parker, M.G. Inhibition of estrogen receptor-DNA binding by the "pure" antiestrogen ICI 164,384 appears to be mediated by impaired receptor dimerization. Proc. Natl. Acad. Sci. USA 1990, 87, 6883-6887. [CrossRef] [PubMed]

137. Kojetin, D.J.; Burris, T.P.; Jensen, E.V.; Khan, S.A. Implications of the binding of tamoxifen to the coactivator recognition site of the estrogen receptor. Endocr. Relat. Cancer 2008, 15, 851-870. [CrossRef] [PubMed]

138. Dutertre, M.; Smith, C.L. Molecular mechanisms of selective estrogen receptor modulator (SERM) action. J. Pharm. Exp. 2000, 295, 431-437.

139. Jordan, V.C. Tamoxifen as the first targeted long-term adjuvant therapy for breast cancer. Endocr. Relat. Cancer 2014, 21, R235-R246. [CrossRef]

140. Jordan, V.C. Tamoxifen: A most unlikely pioneering medicine. Nat. Rev. Drug Discov. 2003, 2, $205-213$. [CrossRef]

141. Furr, B.J.; Jordan, V.C. The pharmacology and clinical uses of tamoxifen. Pharm. Ther. 1984, 25, 127-205. [CrossRef]

142. Davies, C.; Pan, H.; Godwin, J.; Gray, R.; Arriagada, R.; Raina, V.; Abraham, M.; Medeiros Alencar, V.H.; Badran, A.; Bonfill, X.; et al. Long-term effects of continuing adjuvant tamoxifen to 10 years versus stopping at 5 years after diagnosis of oestrogen receptor-positive breast cancer: ATLAS, a randomised trial. Lancet 2013, 381, 805-816. [CrossRef]

143. Robert, N.J. Clinical efficacy of tamoxifen. Oncology 1997, 11, 15-20.

144. Group, E.B.C.T.C. Effects of chemotherapy and hormonal therapy for early breast cancer on recurrence and 15-year survival: An overview of the randomised trials. The Lancet 2005, 365, 1687-1717.

145. Garcia-Becerra, R.; Santos, N.; Diaz, L.; Camacho, J. Mechanisms of resistance to endocrine therapy in breast cancer: Focus on signaling pathways, miRNAs and genetically based resistance. Int. J. Mol. Sci. 2012, 14, 108-145. [CrossRef] [PubMed]

146. Ali, S.; Rasool, M.; Chaoudhry, H.; Pushparaj, P.N.; Jha, P.; Hafiz, A.; Mahfooz, M.; Abdus Sami, G.; Azhar Kamal, M.; Bashir, S.; et al. Molecular mechanisms and mode of tamoxifen resistance in breast cancer. Bioinformation 2016, 12, 135-139. [CrossRef] [PubMed]

147. Osborne, C.K.; Shou, J.; Massarweh, S.; Schiff, R. Crosstalk between estrogen receptor and growth factor receptor pathways as a cause for endocrine therapy resistance in breast cancer. Clin. Cancer Res. 2005, 11, 865 s-870s. 
148. Wei, Y.; Lai, X.; Yu, S.; Chen, S.; Ma, Y.; Zhang, Y.; Li, H.; Zhu, X.; Yao, L.; Zhang, J. Exosomal miR-221/222 enhances tamoxifen resistance in recipient ER-positive breast cancer cells. Breast Cancer Res. Treat. 2014, 147, 423-431. [CrossRef]

149. Miller, T.E.; Ghoshal, K.; Ramaswamy, B.; Roy, S.; Datta, J.; Shapiro, C.L.; Jacob, S.; Majumder, S. MicroRNA-221/222 confers tamoxifen resistance in breast cancer by targeting p27Kip1. J. Biol. Chem. 2008, 283, 29897-29903. [CrossRef]

150. Cittelly, D.M.; Das, P.M.; Spoelstra, N.S.; Edgerton, S.M.; Richer, J.K.; Thor, A.D.; Jones, F.E. Downregulation of miR-342 is associated with tamoxifen resistant breast tumors. Mol. Cancer 2010, 9, 317. [CrossRef]

151. Bergamaschi, A.; Katzenellenbogen, B.S. Tamoxifen downregulation of miR-451 increases 14-3-3zeta and promotes breast cancer cell survival and endocrine resistance. Oncogene 2012, 31, 39-47. [CrossRef]

152. Wang, Q.; Gun, M.; Hong, X.Y. Induced Tamoxifen Resistance is Mediated by Increased Methylation of E-Cadherin in Estrogen Receptor-Expressing Breast Cancer Cells. Sci. Rep. 2019, 9, 14140. [CrossRef]

153. Jögi, A.; Ehinger, A.; Hartman, L.; Alkner, S. Expression of HIF-1 $\alpha$ is related to a poor prognosis and tamoxifen resistance in contralateral breast cancer. PLoS ONE 2019, 14, e0226150. [CrossRef]

154. Ma, T.; Liang, Y.; Li, Y.; Song, X.; Zhang, N.; Li, X.; Chen, B.; Zhao, W.; Wang, L.; Yang, Q. LncRNA LINP1 confers tamoxifen resistance and negatively regulated by ER signaling in breast cancer. Cell. Signal. 2020, 109536. [CrossRef]

155. Fiorillo, M.; Sanchez-Alvarez, R.; Sotgia, F.; Lisanti, M.P. The ER-alpha mutation Y537S confers Tamoxifen-resistance via enhanced mitochondrial metabolism, glycolysis and Rho-GDI/PTEN signaling: Implicating TIGAR in somatic resistance to endocrine therapy. Aging 2018, 10, 4000. [CrossRef]

156. Barkhem, T.; Carlsson, B.; Nilsson, Y.; Enmark, E.; Gustafsson, J.; Nilsson, S. Differential response of estrogen receptor alpha and estrogen receptor beta to partial estrogen agonists/antagonists. Mol. Pharm. 1998, 54, 105-112. [CrossRef] [PubMed]

157. Katzenellenbogen, J.A.; Mayne, C.G.; Katzenellenbogen, B.S.; Greene, G.L.; Chandarlapaty, S. Structural underpinnings of oestrogen receptor mutations in endocrine therapy resistance. Nat. Rev. Cancer 2018, 18, 377-388. [CrossRef] [PubMed]

158. $\mathrm{Ng}$, H.L. Simulations reveal increased fluctuations in estrogen receptor-alpha conformation upon antagonist binding. J. Mol. Graph. Model. 2016, 69, 72-77. [CrossRef] [PubMed]

159. Zeng, J.; Li, W.; Zhao, Y.; Liu, G.; Tang, Y.; Jiang, H. Insights into ligand selectivity in estrogen receptor isoforms: Molecular dynamics simulations and binding free energy calculations. J. Phys. Chem. B 2008, 112, 2719-2726. [CrossRef] [PubMed]

160. MacGregor, J.I.; Jordan, V.C. Basic guide to the mechanisms of antiestrogen action. Pharm. Rev. 1998, 50, 151-196. [PubMed]

161. Jameera Begam, A.; Jubie, S.; Nanjan, M.J. Estrogen receptor agonists/antagonists in breast cancer therapy: A critical review. Bioorg. Chem. 2017, 71, 257-274. [CrossRef] [PubMed]

162. Kallio, S.; Kangas, L.; Blanco, G.; Johansson, R.; Karjalainen, A.; Perila, M.; Pippo, I.; Sundquist, H.; Sodervall, M.; Toivola, R. A new triphenylethylene compound, Fc-1157a. I. Hormonal effects. Cancer Chemother. Pharm. 1986, 17, 103-108. [CrossRef]

163. Kangas, L.; Nieminen, A.L.; Blanco, G.; Gronroos, M.; Kallio, S.; Karjalainen, A.; Perila, M.; Sodervall, M.; Toivola, R. A new triphenylethylene compound, Fc-1157a. II. Antitumor effects. Cancer Chemother. Pharm. 1986, 17, 109-113. [CrossRef]

164. Sharma, D.; Kumar, S.; Narasimhan, B. Estrogen alpha receptor antagonists for the treatment of breast cancer: A review. Chem. Cent. J. 2018, 12, 107. [CrossRef] [PubMed]

165. Martinkovich, S.; Shah, D.; Planey, S.L.; Arnott, J.A. Selective estrogen receptor modulators: Tissue specificity and clinical utility. Clin. Interv. Aging 2014, 9, 1437-1452. [CrossRef] [PubMed]

166. Kuiper, G.G.; Lemmen, J.G.; Carlsson, B.; Corton, J.C.; Safe, S.H.; van der Saag, P.T.; van der Burg, B.; Gustafsson, J.A. Interaction of estrogenic chemicals and phytoestrogens with estrogen receptor beta. Endocrinology 1998, 139, 4252-4263. [CrossRef] [PubMed]

167. Buzdar, A.; Hayes, D.; El-Khoudary, A.; Yan, S.; Lonning, P.; Lichinitser, M.; Gopal, R.; Falkson, G.; Pritchard, K.; Lipton, A.; et al. Phase III randomized trial of droloxifene and tamoxifen as first-line endocrine treatment of ER/PgR-positive advanced breast cancer. Breast Cancer Res. Treat. 2002, 73, 161-175. [CrossRef] 
168. Arpino, G.; Nair Krishnan, M.; Doval Dinesh, C.; Bardou, V.J.; Clark, G.M.; Elledge, R.M. Idoxifene versus tamoxifen: A randomized comparison in postmenopausal patients with metastatic breast cancer. Ann. Oncol. 2003, 14, 233-241. [CrossRef]

169. Milla-Santos, A.; Milla, L.; Rallo, L.; Solano, V. Phase III randomized trial of toremifene vs tamoxifen in hormonodependant advanced breast cancer. Breast Cancer Res. Treat. 2001, 65, 119-124. [CrossRef]

170. Maximov, P.Y.; Lee, T.M.; Jordan, V.C. The discovery and development of selective estrogen receptor modulators (SERMs) for clinical practice. Curr. Clin. Pharm. 2013, 8, 135-155. [CrossRef]

171. Black, L.J.; Goode, R.L. Uterine bioassay of tamoxifen, trioxifene and a new estrogen antagonist (LY117018) in rats and mice. Life Sci. 1980, 26, 1453-1458. [CrossRef]

172. Black, L.J.; Jones, C.D.; Falcone, J.F. Antagonism of estrogen action with a new benzothiophene derived antiestrogen. Life Sci. 1983, 32, 1031-1036. [CrossRef]

173. Buzdar, A.U.; Marcus, C.; Holmes, F.; Hug, V.; Hortobagyi, G. Phase II evaluation of Ly156758 in metastatic breast cancer. Oncology 1988, 45, 344-345. [CrossRef]

174. Palkowitz, A.D.; Glasebrook, A.L.; Thrasher, K.J.; Hauser, K.L.; Short, L.L.; Phillips, D.L.; Muehl, B.S.; Sato, M.; Shetler, P.K.; Cullinan, G.J.; et al. Discovery and synthesis of [6-hydroxy-3-[4-[2-(1-piperidinyl)ethoxy]phenoxy]-2-(4-hydroxyphenyl)]b enzo[b]thiophene: A novel, highly potent, selective estrogen receptor modulator. J. Med. Chem. 1997, 40, 1407-1416. [CrossRef] [PubMed]

175. Cauley, J.A.; Norton, L.; Lippman, M.E.; Eckert, S.; Krueger, K.A.; Purdie, D.W.; Farrerons, J.; Karasik, A.; Mellstrom, D.; Ng, K.W.; et al. Continued breast cancer risk reduction in postmenopausal women treated with raloxifene: 4-year results from the MORE trial. Multiple outcomes of raloxifene evaluation. Breast Cancer Res. Treat. 2001, 65, 125-134. [CrossRef] [PubMed]

176. Cummings, S.R.; Eckert, S.; Krueger, K.A.; Grady, D.; Powles, T.J.; Cauley, J.A.; Norton, L.; Nickelsen, T.; Bjarnason, N.H.; Morrow, M.; et al. The effect of raloxifene on risk of breast cancer in postmenopausal women: Results from the MORE randomized trial. Multiple Outcomes of Raloxifene Evaluation. JAMA 1999, 281, 2189-2197. [CrossRef] [PubMed]

177. Kushwaha, A.K.; Vuddanda, P.R.; Karunanidhi, P.; Singh, S.K.; Singh, S. Development and evaluation of solid lipid nanoparticles of raloxifene hydrochloride for enhanced bioavailability. Biomed. Res. Int. 2013, 2013, 584549. [CrossRef] [PubMed]

178. Schafer, J.M.; Lee, E.S.; Dardes, R.C.; Bentrem, D.; O’Regan, R.M.; De Los Reyes, A.; Jordan, V.C. Analysis of cross-resistance of the selective estrogen receptor modulators arzoxifene (LY353381) and LY117018 in tamoxifen-stimulated breast cancer xenografts. Clin. Cancer Res. 2001, 7, 2505-2512.

179. Suh, N.; Glasebrook, A.L.; Palkowitz, A.D.; Bryant, H.U.; Burris, L.L.; Starling, J.J.; Pearce, H.L.; Williams, C.; Peer, C.; Wang, Y.; et al. Arzoxifene, a new selective estrogen receptor modulator for chemoprevention of experimental breast cancer. Cancer Res. 2001, 61, 8412-8415.

180. Deshmane, V.; Krishnamurthy, S.; Melemed, A.S.; Peterson, P.; Buzdar, A.U. Phase III double-blind trial of arzoxifene compared with tamoxifen for locally advanced or metastatic breast cancer. J. Clin. Oncol. 2007, 25, 4967-4973. [CrossRef]

181. Komm, B.S.; Kharode, Y.P.; Bodine, P.V.; Harris, H.A.; Miller, C.P.; Lyttle, C.R. Bazedoxifene acetate: A selective estrogen receptor modulator with improved selectivity. Endocrinology 2005, 146, 3999-4008. [CrossRef]

182. Patel, H.K.; Bihani, T. Selective estrogen receptor modulators (SERMs) and selective estrogen receptor degraders (SERDs) in cancer treatment. Pharm. Ther. 2018, 186, 1-24. [CrossRef]

183. Wardell, S.E.; Nelson, E.R.; Chao, C.A.; McDonnell, D.P. Bazedoxifene exhibits antiestrogenic activity in animal models of tamoxifen-resistant breast cancer: Implications for treatment of advanced disease. Clin. Cancer Res. 2013, 19, 2420-2431. [CrossRef]

184. Miller, C.P.; Collini, M.D.; Tran, B.D.; Harris, H.A.; Kharode, Y.P.; Marzolf, J.T.; Moran, R.A.; Henderson, R.A.; Bender, R.H.; Unwalla, R.J.; et al. Design, synthesis, and preclinical characterization of novel, highly selective indole estrogens. J. Med. Chem. 2001, 44, 1654-1657. [CrossRef] [PubMed]

185. Goldberg, T.; Fidler, B. Conjugated Estrogens/Bazedoxifene (Duavee): A Novel Agent for the Treatment of Moderate-to-Severe Vasomotor Symptoms Associated with Menopause and the Prevention of Postmenopausal Osteoporosis. Pharm. Ther. 2015, 40, 178-182. 
186. Jeselsohn, R.; Guo, H.; Rees, R.; Barry, W.T.; Barlett, C.H.; Tung, N.M.; Krop, I.E.; Brown, M.; Winer, E.P. Results from the phase $\mathrm{Ib} / \mathrm{II}$ clinical trial of bazedoxifene and palbociclib in hormone receptor positive metastatic breast cancer. In Proceedings of the San Antonio Breast Cancer Symposium, San Antonio, TX, USA, 4-8 December 2019.

187. Fabian, C.J.; Nye, L.; Powers, K.R.; Nydegger, J.L.; Kreutzjans, A.L.; Phillips, T.A.; Metheny, T.; Winblad, O.; Zalles, C.M.; Hagan, C.R.; et al. Effect of Bazedoxifene and Conjugated Estrogen (Duavee) on Breast Cancer Risk Biomarkers in High-Risk Women: A Pilot Study. Cancer Prev. Res. 2019, 12, 711-720. [CrossRef] [PubMed]

188. LaCroix, A.Z.; Powles, T.; Osborne, C.K.; Wolter, K.; Thompson, J.R.; Thompson, D.D.; Allred, D.C.; Armstrong, R.; Cummings, S.R.; Eastell, R.; et al. Breast cancer incidence in the randomized PEARL trial of lasofoxifene in postmenopausal osteoporotic women. J. Natl. Cancer Inst. 2010, 102, 1706-1715. [CrossRef]

189. Goldstein, S.R.; Neven, P.; Cummings, S.; Colgan, T.; Runowicz, C.D.; Krpan, D.; Proulx, J.; Johnson, M.; Thompson, D.; Thompson, J.; et al. Postmenopausal Evaluation and Risk Reduction With Lasofoxifene (PEARL) trial: 5-year gynecological outcomes. Menopause 2011, 18, 17-22. [CrossRef]

190. Plourde, P.V.; Schwartzberg, L.S.; Greene, G.L.; Portman, D.J.; Komm, B.S.; Jenkins, S.N.; Liu, P.Y.; Portman, M.D.; Goetz, M.P. An open-label, randomized, multi-center phase 2 study evaluating the activity of lasofoxifene relative to fulvestrant for the treatment of postmenopausal women with locally advanced or metastatic ER+/HER2-Breast cancer (MBC) with an ESR1 mutation. In Proceedings of the San Antonio Breast Cancer Symposium, San Antonio, TX, USA, 4-8 December 2018.

191. Shiau, A.K.; Barstad, D.; Loria, P.M.; Cheng, L.; Kushner, P.J.; Agard, D.A.; Greene, G.L. The structural basis of estrogen receptor/coactivator recognition and the antagonism of this interaction by tamoxifen. Cell 1998, 95, 927-937. [CrossRef]

192. Vajdos, F.F.; Hoth, L.R.; Geoghegan, K.F.; Simons, S.P.; LeMotte, P.K.; Danley, D.E.; Ammirati, M.J.; Pandit, J. The 2.0 A crystal structure of the ERalpha ligand-binding domain complexed with lasofoxifene. Protein Sci. 2007, 16, 897-905. [CrossRef]

193. Lee, S.; Barron, M.G. Structure-Based Understanding of Binding Affinity and Mode of Estrogen Receptor alpha Agonists and Antagonists. PLoS ONE 2017, 12, e0169607. [CrossRef]

194. Shiau, A.K.; Barstad, D.; Radek, J.T.; Meyers, M.J.; Nettles, K.W.; Katzenellenbogen, B.S.; Katzenellenbogen, J.A.; Agard, D.A.; Greene, G.L. Structural characterization of a subtype-selective ligand reveals a novel mode of estrogen receptor antagonism. Nat. Struct. Biol. 2002, 9, 359-364. [CrossRef]

195. Labrie, F.; Labrie, C.; Belanger, A.; Simard, J.; Gauthier, S.; Luu-The, V.; Merand, Y.; Giguere, V.; Candas, B.; Luo, S.; et al. EM-652 (SCH 57068), a third generation SERM acting as pure antiestrogen in the mammary gland and endometrium. J. Steroid Biochem Mol. Biol. 1999, 69, 51-84. [CrossRef]

196. Couillard, S.; Gutman, M.; Labrie, F.; Candas, B.; Labrie, C. Effect of combined treatment with the pure antiestrogen EM-800 and radiotherapy on the growth of human ZR-75-1 breast cancer xenografts in nude mice. Cancer Res. 1999, 59, 4857-4863. [PubMed]

197. Gutman, M.; Couillard, S.; Labrie, F.; Candas, B.; Labrie, C. Effects of the antiestrogen EM-800 (SCH 57050) and cyclophosphamide alone and in combination on growth of human ZR-75-1 breast cancer xenografts in nude mice. Cancer Res. 1999, 59, 5176-5180. [PubMed]

198. Labrie, F.; Champagne, P.; Labrie, C.; Roy, J.; Laverdiere, J.; Provencher, L.; Potvin, M.; Drolet, Y.; Pollak, M.; Panasci, L.; et al. Activity and safety of the antiestrogen EM-800, the orally active precursor of acolbifene, in tamoxifen-resistant breast cancer. J. Clin. Oncol. 2004, 22, 864-871. [CrossRef] [PubMed]

199. Fabian, C.J.; Kimler, B.F.; Zalles, C.M.; Phillips, T.A.; Metheny, T.; Petroff, B.K.; Havighurst, T.C.; Kim, K.; Bailey, H.H.; Heckman-Stoddard, B.M. Clinical Trial of Acolbifene in Premenopausal Women at High Risk for Breast Cancer. Cancer Prev. Res. 2015, 8, 1146-1155. [CrossRef] [PubMed]

200. Gauthier, S.; Cloutier, J.; Dory, Y.L.; Favre, A.; Mailhot, J.; Ouellet, C.; Schwerdtfeger, A.; Merand, Y.; Martel, C.; Simard, J.; et al. Synthesis and structure-activity relationships of analogs of EM-652 (acolbifene), a pure selective estrogen receptor modulator. Study of nitrogen substitution. J. Enzym. Inhib. Med. Chem. 2005, 20, 165-177. [CrossRef] [PubMed]

201. Sharma, B.; Singh, A.; Gu, L.; Saha, S.T.; Singh-Pillay, A.; Cele, N.; Singh, P.; Kaur, M.; Kumar, V. Diastereoselective approach to rationally design tetrahydro- $\beta$-carboline-isatin conjugates as potential SERMs against breast cancer. RSC Adv. 2019, 9, 9809-9819. [CrossRef] 
202. Hanwell, M.D.; Curtis, D.E.; Lonie, D.C.; Vandermeersch, T.; Zurek, E.; Hutchison, G.R. Avogadro: An advanced semantic chemical editor, visualization, and analysis platform. J. Cheminformatics 2012, 4, 17. [CrossRef]

203. Ultra, C. 6.0 and Chem3D Ultra. Camb. Soft Corp. Camb. USA 2001.

204. Sharma, A.; Toy, W.; Guillen, V.S.; Sharma, N.; Min, J.; Carlson, K.E.; Mayne, C.G.; Lin, S.; Sabio, M.; Greene, G. Antagonists for Constitutively Active Mutant Estrogen Receptors: Insights into the Roles of Antiestrogen-Core and Side-Chain. ACS Chem. Biol. 2018, 13, 3374-3384. [CrossRef]

205. Singla, R.; Prakash, K.; Gupta, K.B.; Upadhyay, S.; Dhiman, M.; Jaitak, V. Identification of novel indole based heterocycles as selective estrogen receptor modulator. Bioorganic Chem. 2018, 79, 72-88. [CrossRef]

206. Luo, J.; Hu, Z.; Xiao, Y.; Yang, T.; Dong, C.; Huang, J.; Zhou, H.-B. Rational design and optimization of selenophenes with basic side chains as novel potent selective estrogen receptor modulators (SERMs) for breast cancer therapy. MedChem Comm 2017, 8, 1485-1497. [CrossRef] [PubMed]

207. Goodsell, D.S.; Morris, G.M.; Olson, A.J. Automated docking of flexible ligands: Applications of AutoDock. J. Mol. Recognit. 1996, 9, 1-5. [CrossRef]

208. Yu, E.; Xu, Y.; Shi, Y.; Yu, Q.; Liu, J.; Xu, L. Discovery of novel natural compound inhibitors targeting estrogen receptor $\alpha$ by an integrated virtual screening strategy. J. Mol. Model. 2019, 25. [CrossRef]

209. Shen, J.; Tan, C.; Zhang, Y.; Li, X.; Li, W.; Huang, J.; Shen, X.; Tang, Y. Discovery of Potent Ligands for Estrogen Receptor $\beta$ by Structure-Based Virtual Screening. J. Med. Chem. 2010, 53, 5361-5365. [CrossRef] [PubMed]

210. Zhang, L.; Sedykh, A.; Tripathi, A.; Zhu, H.; Afantitis, A.; Mouchlis, V.; Melagraki, G.; Rusyn, I.; Tropsha, A. Identification of putative estrogen receptor-mediated endocrine disrupting chemicals using QSAR- and structure-based virtual screening approaches. Toxicol. Appl. Pharmacol. 2013, 272. [CrossRef] [PubMed]

211. McRobb, F.; Kufareva, I.; Abagyan, R. In Silico Identification and Pharmacological Evaluation of Novel Endocrine Disrupting Chemicals that Act via the Ligand-Binding Domain of the Estrogen Receptor. Toxicol. Sci. Off. J. Soc. Toxicol. 2014, 141. [CrossRef]

212. Knox, A.J.S.; Meegan, M.J.; Sobolev, V.; Frost, D.; Zisterer, D.M.; Williams, D.C.; Lloyd, D.G. Target Specific Virtual Screening: Optimization of an Estrogen Receptor Screening Platform. J. Med. Chem. 2007, 50, 5301-5310. [CrossRef]

213. Hendy, M.S.; Ali, A.A.; Ahmed, L.; Hossam, R.; Mostafa, A.; Elmazar, M.; Naguib, B.; Attia, Y.; Ahmed, M. Structure-based drug design, synthesis, In vitro, and In vivo biological evaluation of indole-based biomimetic analogs targeting estrogen receptor- $\alpha$ inhibition. Eur. J. Med. Chem. 2019, 166. [CrossRef]

214. TilakVijay, J.; Babu, K.; Uma, A. Virtual screening of novel compounds as potential ER $\alpha$ inhibitors. Bioinformation 2019, 15, 321-332. [CrossRef]

215. Ng, H.W.; Zhang, W.; Shu, M.; Luo, H.; Ge, W.; Perkins, R.; Tong, W.; Hong, H. Competitive molecular docking approach for predicting estrogen receptor subtype a agonists and antagonists. BMC Bioinform. 2014, 15. [CrossRef]

216. Abdullaha, M.; Ali, M.; Kour, D.; Kumar, A.; Bharate, S.B. Discovery of benzo [cd] indol-2-one and benzylidene-thiazolidine-2, 4-dione as new classes of NLRP3 inflammasome inhibitors via ER- $\beta$ structure based virtual screening. Bioorganic Chem. 2020, 95, 103500. [CrossRef] [PubMed]

217. Zhao, H.; Lin, C.; Hu, K.; Wen, X.; Yuan, H. Discovery of Novel Estrogen-Related Receptor $\alpha$ Inverse Agonists by Virtual Screening and Biological Evaluation. J. Biomol. Struct. Dyn. 2018, 37, 1-24. [CrossRef] [PubMed]

218. Suetsugi, M.; Su, L.; Karlsberg, K.; Yuan, Y.-C.; Chen, S. Flavone and Isoflavone Phytoestrogens Are Agonists of Estrogen-Related Receptors. Mol. Cancer Res. 2003, 1, 981-991.

219. Chen, L.; Wu, D.; Bian, H.-P.; Kuang, G.; Jiang, J.; Li, W.-H.; Liu, G.-X.; Zou, S.-E.; Huang, J.; Tang, Y. Selective ligands of estrogen receptor $\beta$ discovered using pharmacophore mapping and structure-based virtual screening. Acta Pharmacol. Sin. 2014, 35. [CrossRef] [PubMed]

220. Tuccinardi, T.; Poli, G.; Dell'Agnello, M.; Granchi, C.; Minutolo, F.; Martinelli, A. Receptor-based virtual screening evaluation for the identification of estrogen receptor $\beta$ ligands. J. Enzym. Inhib. Med. Chem. 2014, 30, 1-9. [CrossRef]

221. Khan, S.U.; Ahemad, N.; Chuah, L.-H.; Naidu, R.; Htar, T.T. Sequential ligand-and structure-based virtual screening approach for the identification of potential G protein-coupled estrogen receptor-1 (GPER-1) modulators. RSC Adv. 2019, 9, 2525-2538. [CrossRef]

222. Kapetanovic, I. Computer-aided drug discovery and development (CADDD): In silico-chemico-biological approach. Chem. Biol. Interact. 2008, 171, 165-176. [CrossRef] 
223. Istyastono, E.; Riswanto, F.; Yuliani, S.H. Computer-Aided Drug Repurposing: A Cyclooxygenase-2 Inhibitor Celecoxib as a Ligand for Estrogen Receptor Alpha. Indones. J. Chem. 2015, 15, 274-280. [CrossRef]

224. Korb, O.; Stutzle, T.; Exner, T.E. Empirical scoring functions for advanced protein- ligand docking with PLANTS. J. Chem. Inf. Model. 2009, 49, 84-96. [CrossRef]

225. Niinivehmas, S.; Elangovan, M.; Rauhamäki, S.; Huuskonen, J.; Pentikäinen, O. Identification of estrogen receptor $\alpha$ ligands with virtual screening techniques. J. Mol. Graph. Model. 2016, 64, 30-39. [CrossRef]

226. Dixon, S.L.; Smondyrev, A.M.; Rao, S.N. PHASE: A novel approach to pharmacophore modeling and 3D database searching. Chem. Biol. Drug Des. 2006, 67, 370-372. [CrossRef] [PubMed]

227. Release, S. 1: Maestro; Schrödinger LLC: New York, NY, USA, 2017; Volume 2017.

228. Vainio, M.J.; Puranen, J.S.; Johnson, M.S. ShaEP: Molecular Overlay Based on Shape and Electrostatic Potential; ACS Publications: Washington, DC, USA, 2009.

229. Pang, X.; Fu, W.; Wang, J.; Kang, D.; Xu, L.; Zhao, Y.; Liu, A.; Du, G.-H. Identification of Estrogen Receptor $\alpha$ Antagonists from Natural Products via In Vitro and In Silico Approaches. Oxidative Med. Cell. Longev. 2018, 2018, 1-11. [CrossRef]

230. Studio, D. Version 2.5; Accelrys Inc.: San Diego, CA, USA, 2009.

231. Rao, S.N.; Head, M.S.; Kulkarni, A.; LaLonde, J.M. Validation studies of the site-directed docking program LibDock. J. Chem. Inf. Model. 2007, 47, 2159-2171. [CrossRef] [PubMed]

232. Wu, G.; Robertson, D.H.; Brooks III, C.L.; Vieth, M. Detailed analysis of grid-based molecular docking: A case study of CDOCKER-A CHARMm-based MD docking algorithm. J. Comput. Chem. 2003, 24, 1549-1562. [CrossRef] [PubMed]

233. Wang, Z.; Yang, Y.; Zheng, X.; Zhang, T.; Huang, W.; Yan, D.; Zhang, W.; Wang, X.; Shen, Z. Synthesis and biological evaluation of novel cyclopropyl derivatives as subtype-selective ligands for estrogen receptor. $J$. Pharm. Pharmacol. 2018, 70, 910-918. [CrossRef]

234. Jin, L.-P.; Xie, Q.; Huang, E.-F.; Wang, L.; Zhang, B.-Q.; Hu, J.-S.; Wan, D.; Zhe, J.; Hu, C. Design, Synthesis, and Biological Activity of a Novel Series of Benzofuran Derivatives Against Oestrogen Receptor-Dependent Breast Cancer Cell Lines. Bioorganic Chem. 2020, 95, 103566. [CrossRef]

235. Boström, J.; Greenwood, J.R.; Gottfries, J. Assessing the performance of OMEGA with respect to retrieving bioactive conformations. J. Mol. Graph. Model. 2003, 21, 449-462. [CrossRef]

236. McGann, M. FRED pose prediction and virtual screening accuracy. J. Chem. Inf. Model. 2011, 51, 578-596. [CrossRef] [PubMed]

237. Pavlin, M.; Gelsomino, L.; Barone, I.; Spinello, A.; Catalano, S.; Ando, S.; Magistrato, A. Structural, Thermodynamic, and Kinetic Traits of Antiestrogen-Compounds Selectively Targeting the Y537S Mutant Estrogen Receptor alpha Transcriptional Activity in Breast Cancer Cell Lines. Front. Chem. 2019, 7, 602. [CrossRef] [PubMed]

238. Anita, Y.; Radifar, M.; Kardono, L.B.; Hanafi, M.; Istyastono, E.P. Structure-based design of eugenol analogs as potential estrogen receptor antagonists. Bioinformation 2012, 8, 901-906. [CrossRef] [PubMed]

239. Istyastono, E.; Anita, Y.; Sundowo, A. Computer-Aided Structure-Based Design of 3,3'-Diallyl-[1,1'-biphenyl]4,4'- diol Analogs of Eugenol as Potential Ligands for Estrogen Receptor Alpha. In Proceedings of the 3rd International Conference on Computation for Science and Technology (ICCST-3), Bali, Indonesia, 23-25 September 2014; Atlantis Press: Paris, France, 2015. [CrossRef]

240. Muchtaridi, M.; Syahidah, H.N.; Subarnas, A.; Yusuf, M.; Bryant, S.D.; Langer, T. Molecular Docking and 3D-Pharmacophore Modeling to Study the Interactions of Chalcone Derivatives with Estrogen Receptor Alpha. Pharmaceuticals 2017, 10, 81. [CrossRef] [PubMed]

241. Wolber, G.; Langer, T. LigandScout: 3-D pharmacophores derived from protein-bound ligands and their use as virtual screening filters. J. Chem. Inf. Model. 2005, 45, 160-169. [CrossRef] [PubMed]

242. Munir, A.; Azam, S.; Mehmood, A.; Khan, Z.; Mehmood, A.; Aqdas, S. Structure-Based Pharmacophore Modeling, Virtual Screening and Molecular docking for the Treatment of ESR1 Mutations in Breast Cancer. Drug Des. 2016, 5, 137. [CrossRef]

243. Schneidman-Duhovny, D.; Inbar, Y.; Nussinov, R.; Wolfson, H.J. PatchDock and SymmDock: Servers for rigid and symmetric docking. Nucleic Acids Res. 2005, 33, W363-W367. [CrossRef] [PubMed]

244. McDonnell, D.P.; Connor, C.E.; Wijayaratne, A.; Chang, C.-Y.; Norris, J.D. Definition of the molecular and cellular mechanisms underlying the tissue-selective agonist/antagonist activities of selective estrogen receptor modulators. Recent Prog. Horm. Res. 2002, 57, 295-316. [CrossRef] 
245. Robertson, J.F. Fulvestrant (Faslodex)—How to make a good drug better. Oncologist 2007, 12, 774-784. [CrossRef]

246. Osborne, C.K.; Wakeling, A.; Nicholson, R.I. Fulvestrant: An oestrogen receptor antagonist with a novel mechanism of action. Br. J. Cancer 2004, 90, S2-S6. [CrossRef] [PubMed]

247. Liu, J.; Li, J.; Wang, H.; Wang, Y.; He, Q.; Xia, X.; Hu, Z.Y.; Ouyang, Q. Clinical and genetic risk factors for Fulvestrant treatment in post-menopause ER-positive advanced breast cancer patients. J. Transl. Med. 2019, 17, 27. [CrossRef] [PubMed]

248. Carlson, R.W. The history and mechanism of action of fulvestrant. Clin. Breast Cancer 2005, 6, S5-S8. [CrossRef] [PubMed]

249. Dauvois, S.; White, R.; Parker, M.G. The antiestrogen ICI 182780 disrupts estrogen receptor nucleocytoplasmic shuttling. J. Cell Sci. 1993, 106, 1377-1388. [PubMed]

250. Nathan, M.R.; Schmid, P. A Review of Fulvestrant in Breast Cancer. Oncol. Ther. 2017, 5, 17-29. [CrossRef] [PubMed]

251. Nicholson, R.I.; Gee, J.M.; Manning, D.L.; Wakeling, A.E.; Montano, M.M.; Katzenellenbogen, B.S. Responses to pure antiestrogens (ICI 164384, ICI 182780) in estrogen-sensitive and -resistant experimental and clinical breast cancer. Ann. N. Y. Acad. Sci. 1995, 761, 148-163. [CrossRef] [PubMed]

252. Lai, A.C.; Crews, C.M. Induced protein degradation: An emerging drug discovery paradigm. Nat. Rev. Drug Discov. 2017, 16, 101-114. [CrossRef]

253. Tria, G.S.; Abrams, T.; Baird, J.; Burks, H.E.; Firestone, B.; Gaither, L.A.; Hamann, L.G.; He, G.; Kirby, C.A.; Kim, S.; et al. Discovery of LSZ102, a Potent, Orally Bioavailable Selective Estrogen Receptor Degrader (SERD) for the Treatment of Estrogen Receptor Positive Breast Cancer. J. Med. Chem. 2018, 61, 2837-2864. [CrossRef] [PubMed]

254. Wakeling, A.E. Regulatory mechanisms in breast cancer. Steroidal pure antiestrogens. Cancer Treat. Res. 1991, 53, 239-257.

255. Wakeling, A.E.; Dukes, M.; Bowler, J. A potent specific pure antiestrogen with clinical potential. Cancer Res. 1991, 51, 3867-3873. [PubMed]

256. Robertson, J.F.; Harrison, M. Fulvestrant: Pharmacokinetics and pharmacology. Br. J. Cancer 2004, 90 (Suppl. 1), S7-S10. [CrossRef]

257. De Savi, C.; Bradbury, R.H.; Rabow, A.A.; Norman, R.A.; de Almeida, C.; Andrews, D.M.; Ballard, P.; Buttar, D.; Callis, R.J.; Currie, G.S.; et al. Optimization of a Novel Binding Motif to (E)-3-(3,5-Difluoro-4-((1R,3R)-2-(2-fluoro-2-methylpropyl)-3-methyl-2,3,4,9-tetra hydro-1H-pyrido[3,4-b]indol-1-yl)phenyl)acrylic Acid (AZD9496), a Potent and Orally Bioavailable Selective Estrogen Receptor Downregulator and Antagonist. J. Med. Chem. 2015, 58, 8128-8140. [CrossRef] [PubMed]

258. Weir, H.M.; Bradbury, R.H.; Lawson, M.; Rabow, A.A.; Buttar, D.; Callis, R.J.; Curwen, J.O.; de Almeida, C.; Ballard, P.; Hulse, M.; et al. AZD9496: An Oral Estrogen Receptor Inhibitor That Blocks the Growth of ER-Positive and ESR1-Mutant Breast Tumors in Preclinical Models. Cancer Res. 2016, 76, 3307-3318. [CrossRef] [PubMed]

259. Wu, Y.L.; Yang, X.; Ren, Z.; McDonnell, D.P.; Norris, J.D.; Willson, T.M.; Greene, G.L. Structural basis for an unexpected mode of SERM-mediated ER antagonism. Mol. Cell 2005, 18, 413-424. [CrossRef] [PubMed]

260. Hamilton, E.P.; Patel, M.R.; Armstrong, A.C.; Baird, R.D.; Jhaveri, K.; Hoch, M.; Klinowska, T.; Lindemann, J.P.O.; Morgan, S.R.; Schiavon, G.; et al. A First-in-Human Study of the New Oral Selective Estrogen Receptor Degrader AZD9496 for ER(+)/HER2(-) Advanced Breast Cancer. Clin. Cancer Res. 2018, 24, 3510-3518. [CrossRef] [PubMed]

261. Nardone, A.; Weir, H.; Delpuech, O.; Brown, H.; De Angelis, C.; Cataldo, M.L.; Fu, X.; Shea, M.J.; Mitchell, T.; Veeraraghavan, J.; et al. The oral selective oestrogen receptor degrader (SERD) AZD9496 is comparable to fulvestrant in antagonising ER and circumventing endocrine resistance. Br. J. Cancer 2019, 120, 331-339. [CrossRef] [PubMed]

262. Bardia, A.; Aftimos, P.; Bihani, T.; Anderson-Villaluz, A.T.; Jung, J.; Conlan, M.G.; Kaklamani, V.G. EMERALD: Phase III trial of elacestrant (RAD1901) vs endocrine therapy for previously treated ER+ advanced breast cancer. Future Oncol. 2019, 15, 3209-3218. [CrossRef] [PubMed]

263. Garner, F.; Shomali, M.; Paquin, D.; Lyttle, C.R.; Hattersley, G. RAD1901: A novel, orally bioavailable selective estrogen receptor degrader that demonstrates antitumor activity in breast cancer xenograft models. Anticancer Drugs 2015, 26, 948-956. [CrossRef] 
264. Wardell, S.E.; Nelson, E.R.; Chao, C.A.; Alley, H.M.; McDonnell, D.P. Evaluation of the pharmacological activities of RAD1901, a selective estrogen receptor degrader. Endocr. Relat. Cancer 2015, 22, 713-724. [CrossRef]

265. Bihani, T.; Patel, H.K.; Arlt, H.; Tao, N.; Jiang, H.; Brown, J.L.; Purandare, D.M.; Hattersley, G.; Garner, F. Elacestrant (RAD1901), a Selective Estrogen Receptor Degrader (SERD), Has Antitumor Activity in Multiple ER(+) Breast Cancer Patient-derived Xenograft Models. Clin. Cancer Res. 2017, 23, 4793-4804. [CrossRef]

266. Patel, H.; Tao, N.; Arlt, H.; Bihani, T. Anti-tumor activity of elacestrant (RAD1901) in models harboring ESR1 mutations resistant to standard of care therapies. In Proceedings of the San Antonio Breast Cancer Symposium, San Antonio, TX, USA, 4-8 December 2019.

267. Juric, D.; Curigliano, G.; Cresta, S.; Yap, Y.S.; Terret, C.; Duhoux, F.P.; Takahashi, S.; Kundamal, N.; Bhansali, S.; Liao, S.; et al. Phase I/lb study of the SERD LSZ102 alone or in combination with ribociclib in ER+ breast cancer. In Proceedings of the San Antonio Breast Cancer Symposium, San Antonio, TX, USA, 5-9 December 2018.

268. Kahraman, M.; Govek, S.P.; Nagasawa, J.Y.; Lai, A.; Bonnefous, C.; Douglas, K.; Sensintaffar, J.; Liu, N.; Lee, K.; Aparicio, A.; et al. Maximizing ER-alpha Degradation Maximizes Activity in a Tamoxifen-Resistant Breast Cancer Model: Identification of GDC-0927. ACS Med. Chem. Lett. 2019, 10, 50-55. [CrossRef]

269. Dickler, M.N.; Villanueva, R.; Fidalgo, J.P.; Mayer, I.A.; Boni, V.; Winer, E.P.; Hamilton, E.P.; Bellet, M.; Urruticoechea, A.; Gonzalez-Martin, A.; et al. A first-in-human phase I study to evaluate the oral selective estrogen receptor degrader (SERD), GDC-0927, in postmenopausal women with estrogen receptor positive $(\mathrm{ER}+)$ HER2-negative metastatic breast cancer (BC). In Proceedings of the San Antonio Breast Cancer Symposium, San Antonio, TX, USA, 5-9 December 2018.

270. Labadie, S.S.; Li, J.; Blake, R.A.; Chang, J.H.; Goodacre, S.; Hartman, S.J.; Liang, W.; Kiefer, J.R.; Kleinheinz, T.; Lai, T. Discovery of a C-8 hydroxychromene as a potent degrader of estrogen receptor alpha with improved rat oral exposure over GDC-0927. Bioorganic Med. Chem. Lett. 2019, 29, 2090-2093. [CrossRef]

271. Sakamoto, K.M.; Kim, K.B.; Verma, R.; Ransick, A.; Stein, B.; Crews, C.M.; Deshaies, R.J. Development of Protacs to target cancer-promoting proteins for ubiquitination and degradation. Mol. Cell Proteom. 2003, 2, 1350-1358. [CrossRef]

272. Rodriguez-Gonzalez, A.; Cyrus, K.; Salcius, M.; Kim, K.; Crews, C.M.; Deshaies, R.J.; Sakamoto, K.M. Targeting steroid hormone receptors for ubiquitination and degradation in breast and prostate cancer. Oncogene 2008, 27, 7201-7211. [CrossRef]

273. Cyrus, K.; Wehenkel, M.; Choi, E.Y.; Lee, H.; Swanson, H.; Kim, K.B. Jostling for position: Optimizing linker location in the design of estrogen receptor-targeting PROTACs. ChemMedChem 2010, 5, 979-985. [CrossRef]

274. Cyrus, K.; Wehenkel, M.; Choi, E.Y.; Swanson, H.; Kim, K.B. Two-headed PROTAC: An effective new tool for targeted protein degradation. Chembiochem 2010, 11, 1531-1534. [CrossRef] [PubMed]

275. Itoh, Y.; Kitaguchi, R.; Ishikawa, M.; Naito, M.; Hashimoto, Y. Design, synthesis and biological evaluation of nuclear receptor-degradation inducers. Bioorg. Med. Chem. 2011, 19, 6768-6778. [CrossRef] [PubMed]

276. Okuhira, K.; Demizu, Y.; Hattori, T.; Ohoka, N.; Shibata, N.; Nishimaki-Mogami, T.; Okuda, H.; Kurihara, M.; Naito, M. Development of hybrid small molecules that induce degradation of estrogen receptor-alpha and necrotic cell death in breast cancer cells. Cancer Sci. 2013, 104, 1492-1498. [CrossRef] [PubMed]

277. Jiang, Y.; Deng, Q.; Zhao, H.; Xie, M.; Chen, L.; Yin, F.; Qin, X.; Zheng, W.; Zhao, Y.; Li, Z. Development of Stabilized Peptide-Based PROTACs against Estrogen Receptor alpha. ACS Chem. Biol. 2018, 13, 628-635. [CrossRef] [PubMed]

278. Wang, L.; Guillen, V.S.; Sharma, N.; Flessa, K.; Min, J.; Carlson, K.E.; Toy, W.; Braqi, S.; Katzenellenbogen, B.S.; Katzenellenbogen, J.A.; et al. New Class of Selective Estrogen Receptor Degraders (SERDs): Expanding the Toolbox of PROTAC Degrons. ACS Med. Chem. Lett. 2018, 9, 803-808. [CrossRef] [PubMed]

279. Hu, J.; Hu, B.; Wang, M.; Xu, F.; Miao, B.; Yang, C.Y.; Wang, M.; Liu, Z.; Hayes, D.F.; Chinnaswamy, K.; et al. Discovery of ERD-308 as a Highly Potent Proteolysis Targeting Chimera (PROTAC) Degrader of Estrogen Receptor (ER). J. Med. Chem. 2019, 62, 1420-1442. [CrossRef] [PubMed]

280. Hamilton, E.P.; Dees, E.C.; Wang, J.S.; Kim, A.; Korpal, M.; Rimkunas, V.; Rioux, N.; Schindler, J.; Juric, D. Phase I dose escalation of H3B-6545, a first-in-class highly Selective ER $\alpha$ Covalent Antagonist (SERCA), in women with ER-positive, HER2-negative breast cancer (HR+ BC). J. Clin. Oncol. 2019. [CrossRef]

281. Puyang, X.; Furman, C.; Zheng, G.Z.; Wu, Z.J.; Banka, D.; Aithal, K.; Agoulnik, S.; Bolduc, D.M.; Buonamici, S.; Caleb, B.; et al. Discovery of Selective Estrogen Receptor Covalent Antagonists for the Treatment of ERalpha(WT) and ERalpha(MUT) Breast Cancer. Cancer Discov. 2018, 8, 1176-1193. [CrossRef] 
282. Furman, C.; Hao, M.H.; Prajapati, S.; Reynolds, D.; Rimkunas, V.; Zheng, G.Z.; Zhu, P.; Korpal, M. Estrogen Receptor Covalent Antagonists: The Best Is Yet to Come. Cancer Res. 2019, 79, 1740-1745. [CrossRef]

283. Hao, L.; Rizzo, P.; Osipo, C.; Pannuti, A.; Wyatt, D.; Cheung, L.W.; Sonenshein, G.; Osborne, B.A.; Miele, L. Notch-1 activates estrogen receptor-alpha-dependent transcription via IKKalpha in breast cancer cells. Oncogene 2010, 29, 201-213. [CrossRef] [PubMed]

284. Raj, G.V.; Sareddy, G.R.; Ma, S.; Lee, T.K.; Viswanadhapalli, S.; Li, R.; Liu, X.; Murakami, S.; Chen, C.C.; Lee, W.R.; et al. Estrogen receptor coregulator binding modulators (ERXs) effectively target estrogen receptor positive human breast cancers. Elife 2017, 6. [CrossRef]

285. He, B.; Wilson, E.M. Electrostatic modulation in steroid receptor recruitment of LXXLL and FXXLF motifs. Mol. Cell. Biol. 2003, 23, 2135-2150. [CrossRef] [PubMed]

286. Ekoue, D.N.; Unni, N.; Raj, G.V. A new class of agents for estrogen-receptor-positive breast cancer. Expert Rev. Clin. Pharm. 2018, 11, 325-328. [CrossRef] [PubMed]

287. Viswanadhapalli, S.; Ma, S.; Lee, T.K.; Sareddy, G.R.; Liu, X.; Ekoue, D.; Alluri, A.; Luo, Y.; Kassees, K.; Arteaga, C.; et al. Enhancing the activity of a novel estrogen receptor coregulator binding modulator (ERX-11) against ER-positive therapy resistant breast cancer. In Proceedings of the San Antonio Breast Cancer Symposium, San Antonio, TX, USA, 4-8 December 2019.

288. Viswanadhapalli, S.; Sareddy, G.R.; Ma, S.H.; Lee, T.K.; Tekmal, R.R.; Ahn, J.M.; Raj, G.; Vadlamudi, R.K. Novel ERX-11 and CDK4/6 inhibitor combination therapy for treating therapy resistant breast cancer. In Proceedings of the AACR Annual Meeting, Washington, DC, USA, 1-5 April 2017.

289. Rodriguez, A.L.; Tamrazi, A.; Collins, M.L.; Katzenellenbogen, J.A. Design, synthesis, and in vitro biological evaluation of small molecule inhibitors of estrogen receptor alpha coactivator binding. J. Med. Chem. 2004, 47, 600-611. [CrossRef] [PubMed]

290. Zhou, H.B.; Collins, M.L.; Gunther, J.R.; Comninos, J.S.; Katzenellenbogen, J.A. Bicyclo[2.2.2]octanes: Close structural mimics of the nuclear receptor-binding motif of steroid receptor coactivators. Bioorg. Med. Chem. Lett. 2007, 17, 4118-4122. [CrossRef] [PubMed]

291. Parent, A.A.; Gunther, J.R.; Katzenellenbogen, J.A. Blocking estrogen signaling after the hormone: Pyrimidine-core inhibitors of estrogen receptor-coactivator binding. J. Med. Chem. 2008, 51, 6512-6530. [CrossRef]

292. Gunther, J.R.; Moore, T.W.; Collins, M.L.; Katzenellenbogen, J.A. Amphipathic benzenes are designed inhibitors of the estrogen receptor alpha/steroid receptor coactivator interaction. ACS Chem. Biol. 2008, 3, 282-286. [CrossRef]

293. Sun, A.; Moore, T.W.; Gunther, J.R.; Kim, M.S.; Rhoden, E.; Du, Y.; Fu, H.; Snyder, J.P.; Katzenellenbogen, J.A. Discovering small-molecule estrogen receptor alpha/coactivator binding inhibitors: High-throughput screening, ligand development, and models for enhanced potency. ChemMedChem 2011, 6, 654-666. [CrossRef] [PubMed]

294. Becerril, J.; Hamilton, A.D. Helix mimetics as inhibitors of the interaction of the estrogen receptor with coactivator peptides. Angew. Chem. Int. Ed. Engl. 2007, 46, 4471-4473. [CrossRef]

295. Shao, D.; Berrodin, T.J.; Manas, E.; Hauze, D.; Powers, R.; Bapat, A.; Gonder, D.; Winneker, R.C.; Frail, D.E. Identification of novel estrogen receptor alpha antagonists. J. Steroid Biochem. Mol. Biol. 2004, 88, 351-360. [CrossRef] [PubMed]

296. LaFrate, A.L.; Gunther, J.R.; Carlson, K.E.; Katzenellenbogen, J.A. Synthesis and biological evaluation of guanylhydrazone coactivator binding inhibitors for the estrogen receptor. Bioorg. Med. Chem. 2008, 16, 10075-10084. [CrossRef] [PubMed]

297. Singh, K.; Munuganti, R.S.; Leblanc, E.; Lin, Y.L.; Leung, E.; Lallous, N.; Butler, M.; Cherkasov, A.; Rennie, P.S. In silico discovery and validation of potent small-molecule inhibitors targeting the activation function 2 site of human oestrogen receptor alpha. Breast Cancer Res. 2015, 17, 27. [CrossRef]

298. Zsoldos, Z.; Reid, D.; Simon, A.; Sadjad, S.B.; Johnson, A.P. eHiTS: A new fast, exhaustive flexible ligand docking system. J. Mol. Graph. Model. 2007, 26, 198-212. [CrossRef] [PubMed]

299. Skowron, K.J.; Booker, K.; Cheng, C.; Creed, S.; David, B.P.; Lazzara, P.R.; Lian, A.; Siddiqui, Z.; Speltz, T.E.; Moore, T.W. Steroid receptor/coactivator binding inhibitors: An update. Mol. Cell. Endocrinol. 2019, 493, 110471. [CrossRef] [PubMed] 
300. Singh, K.; Munuganti, R.S.N.; Lallous, N.; Dalal, K.; Yoon, J.S.; Sharma, A.; Yamazaki, T.; Cherkasov, A.; Rennie, P.S. Benzothiophenone Derivatives Targeting Mutant Forms of Estrogen Receptor-alpha in Hormone-Resistant Breast Cancers. Int. J. Mol. Sci. 2018, 19. [CrossRef]

301. Wang, L.H.; Yang, X.Y.; Zhang, X.; Mihalic, K.; Fan, Y.X.; Xiao, W.; Howard, O.M.; Appella, E.; Maynard, A.T.; Farrar, W.L. Suppression of breast cancer by chemical modulation of vulnerable zinc fingers in estrogen receptor. Nat. Med. 2004, 10, 40-47. [CrossRef]

302. Wang, L.H.; Yang, X.Y.; Zhang, X.; An, P.; Kim, H.J.; Huang, J.; Clarke, R.; Osborne, C.K.; Inman, J.K.; Appella, E.; et al. Disruption of estrogen receptor DNA-binding domain and related intramolecular communication restores tamoxifen sensitivity in resistant breast cancer. Cancer Cell 2006, 10, 487-499. [CrossRef] [PubMed]

303. Shapiro, D.J.; Mao, C.; Cherian, M.T. Small molecule inhibitors as probes for estrogen and androgen receptor action. J. Biol. Chem. 2011, 286, 4043-4048. [CrossRef]

304. Maynard, A.T.; Covell, D.G. Reactivity of zinc finger cores: Analysis of protein packing and electrostatic screening. J. Am. Chem. Soc. 2001, 123, 1047-1058. [CrossRef]

305. Hilliard, M.; Frohnert, C.; Spillner, C.; Marcone, S.; Nath, A.; Lampe, T.; Fitzgerald, D.J.; Kehlenbach, R.H. The anti-inflammatory prostaglandin 15-deoxy-delta(12,14)-PGJ2 inhibits CRM1-dependent nuclear protein export. J. Biol. Chem. 2010, 285, 22202-22210. [CrossRef] [PubMed]

306. Kim, H.J.; Kim, J.Y.; Meng, Z.; Wang, L.H.; Liu, F.; Conrads, T.P.; Burke, T.R.; Veenstra, T.D.; Farrar, W.L. 15-deoxy-Delta12,14-prostaglandin J2 inhibits transcriptional activity of estrogen receptor-alpha via covalent modification of DNA-binding domain. Cancer Res. 2007, 67, 2595-2602. [CrossRef]

307. Veras Ribeiro Filho, H.; Tambones, I.L.; Mariano Goncalves Dias, M.; Bernardi Videira, N.; Bruder, M.; Amorim Amato, A.; Migliorini Figueira, A.C. Modulation of nuclear receptor function: Targeting the protein-DNA interface. Mol. Cell. Endocrinol. 2019, 484, 1-14. [CrossRef] [PubMed]

308. Mao, C.; Patterson, N.M.; Cherian, M.T.; Aninye, I.O.; Zhang, C.; Montoya, J.B.; Cheng, J.; Putt, K.S.; Hergenrother, P.J.; Wilson, E.M.; et al. A new small molecule inhibitor of estrogen receptor alpha binding to estrogen response elements blocks estrogen-dependent growth of cancer cells. J. Biol. Chem. 2008, 283, 12819-12830. [CrossRef] [PubMed]

309. Caboni, L.; Lloyd, D.G. Beyond the ligand-binding pocket: Targeting alternate sites in nuclear receptors. Med. Res. Rev. 2013, 33, 1081-1118. [CrossRef] [PubMed]

310. Schultz, D.J.; Wickramasinghe, N.S.; Ivanova, M.M.; Isaacs, S.M.; Dougherty, S.M.; Imbert-Fernandez, Y.; Cunningham, A.R.; Chen, C.; Klinge, C.M. Anacardic acid inhibits estrogen receptor alpha-DNA binding and reduces target gene transcription and breast cancer cell proliferation. Mol. Cancer 2010, 9, 594-605. [CrossRef]

311. Jain, A.N. Surflex: Fully automatic flexible molecular docking using a molecular similarity-based search engine. J. Med. Chem. 2003, 46, 499-511. [CrossRef]

312. Zhao, Q.; Zhang, X.; Cai, H.; Zhang, P.; Kong, D.; Ge, X.; Du, M.; Liang, R.; Dong, W. Anticancer effects of plant derived Anacardic acid on human breast cancer MDA-MB-231 cells. Am. J. Transl. Res. 2018, 10, 2424-2434.

313. Li, H.; Nie, L.; Huo, Q.; Zhao, S.; Ma, T.; Wu, C.; Liu, H. [Effect of anacardic acid, a Hsp90 inhibitor, on proliferation, invasion and migration of breast cancer MDA-MB-231 cells]. J. South. Med Univ. 2015, 35, 355-359.

314. Schultz, D.J.; Krishna, A.; Vittitow, S.L.; Alizadeh-Rad, N.; Muluhngwi, P.; Rouchka, E.C.; Klinge, C.M. Transcriptomic response of breast cancer cells to anacardic acid. Sci. Rep. 2018, 8, 8063. [CrossRef] [PubMed]

315. Powell, E.; Xu, W. Intermolecular interactions identify ligand-selective activity of estrogen receptor alpha/beta dimers. Proc. Natl. Acad. Sci. USA 2008, 105, 19012-19017. [CrossRef] [PubMed]

316. Powell, C.E.; Soto, A.M.; Sonnenschein, C. Identification and characterization of membrane estrogen receptor from MCF7 estrogen-target cells. J. Steroid Biochem. Mol. Biol. 2001, 77, 97-108. [CrossRef]

317. Powell, E.; Shanle, E.; Brinkman, A.; Li, J.; Keles, S.; Wisinski, K.B.; Huang, W.; Xu, W. Identification of estrogen receptor dimer selective ligands reveals growth-inhibitory effects on cells that co-express ERalpha and ERbeta. PLoS ONE 2012, 7, e30993. [CrossRef] [PubMed]

318. Coriano, C.G.; Liu, F.; Sievers, C.K.; Liang, M.; Wang, Y.; Lim, Y.; Yu, M.; Xu, W. A Computational-Based Approach to Identify Estrogen Receptor alpha/beta Heterodimer Selective Ligands. Mol. Pharm. 2018, 93, 197-207. [CrossRef] [PubMed] 
319. Richmond, N.J.; Abrams, C.A.; Wolohan, P.R.; Abrahamian, E.; Willett, P.; Clark, R.D. GALAHAD: 1. Pharmacophore identification by hypermolecular alignment of ligands in 3D. J. Comput. Aided Mol. Des. 2006, 20, 567-587. [CrossRef]

320. Jackson, R.M. Q-fit: A probabilistic method for docking molecular fragments by sampling low energy conformational space. J. Comput. Aided Mol. Des. 2002, 16, 43-57. [CrossRef] [PubMed]

321. Wells, J.A.; McClendon, C.L. Reaching for high-hanging fruit in drug discovery at protein-protein interfaces. Nature 2007, 450, 1001-1009. [CrossRef]

322. Estebanez-Perpina, E.; Arnold, L.A.; Nguyen, P.; Rodrigues, E.D.; Mar, E.; Bateman, R.; Pallai, P.; Shokat, K.M.; Baxter, J.D.; Guy, R.K.; et al. A surface on the androgen receptor that allosterically regulates coactivator binding. Proc. Natl. Acad. Sci. USA 2007, 104, 16074-16079. [CrossRef]

323. Tan, M.H.; Li, J.; Xu, H.E.; Melcher, K.; Yong, E.L. Androgen receptor: Structure, role in prostate cancer and drug discovery. Acta Pharm. Sin. 2015, 36, 3-23. [CrossRef]

324. Lack, N.A.; Axerio-Cilies, P.; Tavassoli, P.; Han, F.Q.; Chan, K.H.; Feau, C.; LeBlanc, E.; Guns, E.T.; Guy, R.K.; Rennie, P.S.; et al. Targeting the binding function 3 (BF3) site of the human androgen receptor through virtual screening. J. Med. Chem. 2011, 54, 8563-8573. [CrossRef]

325. Ban, F.; Leblanc, E.; Li, H.; Munuganti, R.S.; Frewin, K.; Rennie, P.S.; Cherkasov, A. Discovery of $1 \mathrm{H}$-indole-2-carboxamides as novel inhibitors of the androgen receptor binding function 3 (BF3). J. Med. Chem. 2014, 57, 6867-6872. [CrossRef] [PubMed]

326. Buzon, V.; Carbo, L.R.; Estruch, S.B.; Fletterick, R.J.; Estebanez-Perpina, E. A conserved surface on the ligand binding domain of nuclear receptors for allosteric control. Mol. Cell. Endocrinol. 2012, 348, 394-402. [CrossRef] [PubMed]

327. Huang, N.; Shoichet, B.K.; Irwin, J.J. Benchmarking sets for molecular docking. J. Med. Chem. 2006, 49, 6789-6801. [CrossRef]

328. Mysinger, M.M.; Carchia, M.; Irwin, J.J.; Shoichet, B.K. Directory of useful decoys, enhanced (DUD-E): Better ligands and decoys for better benchmarking. J. Med. Chem. 2012, 55, 6582-6594. [CrossRef]

329. Meng, E.C.; Shoichet, B.K.; Kuntz, I.D. Automated docking with grid-based energy evaluation. J. Comput. Chem. 1992, 13, 505-524. [CrossRef]

330. Durrant, J.D.; Carlson, K.E.; Martin, T.A.; Offutt, T.L.; Mayne, C.G.; Katzenellenbogen, J.A.; Amaro, R.E. Neural-Network Scoring Functions Identify Structurally Novel Estrogen-Receptor Ligands. J. Chem. Inf. Model. 2015, 55, 1953-1961. [CrossRef] [PubMed]

331. Vogel, S.M.; Bauer, M.R.; Boeckler, F.M. DEKOIS: Demanding evaluation kits for objective in silico screening-a versatile tool for benchmarking docking programs and scoring functions. J. Chem. Inf. Model. 2011, 51, 2650-2665. [CrossRef]

332. Wallach, I.; Lilien, R. Virtual decoy sets for molecular docking benchmarks. J. Chem. Inf. Model. 2011, 51, 196-202. [CrossRef] [PubMed]

333. Istyastono, E.P.; Yuniarti, N.; Hariono, M.; Yuliani, S.; Riswanto, F.D.O. Binary quantitative structure-activity relationship analysis in retrospective structure based virtual screening campaigns targeting estrogen receptor alpha. Asian J. Pharm. Clin. Res. 2017, 10, 206-211. [CrossRef]

334. Réau, M.; Langenfeld, F.; Zagury, J.-F.; Lagarde, N.; Montes, M. Decoys selection in benchmarking datasets: Overview and perspectives. Front. Pharmacol. 2018, 9, 11. [CrossRef]

335. EDSTAC. Endocrine Disruptor Screening and Testing Advisory Committee (EDSTAC) Final Report; Office of Prevention, Pesticides, and Toxic Substances, US Environmental: Waltham, MA, USA, 1998.

336. Dix, D.J.; Houck, K.A.; Martin, M.T.; Richard, A.M.; Setzer, R.W.; Kavlock, R.J. The ToxCast program for prioritizing toxicity testing of environmental chemicals. Toxicol. Sci. 2007, 95, 5-12. [CrossRef] [PubMed]

337. Judson, R.S.; Houck, K.A.; Kavlock, R.J.; Knudsen, T.B.; Martin, M.T.; Mortensen, H.M.; Reif, D.M.; Rotroff, D.M.; Shah, I.; Richard, A.M.; et al. In vitro screening of environmental chemicals for targeted testing prioritization: The ToxCast project. Environ. Health Perspect. 2010, 118, 485-492. [CrossRef] [PubMed]

338. Tice, R.R.; Austin, C.P.; Kavlock, R.J.; Bucher, J.R. Improving the human hazard characterization of chemicals: A Tox21 update. Environ. Health Perspect. 2013, 121, 756-765. [CrossRef] [PubMed]

339. Huang, R.; Sakamuru, S.; Martin, M.T.; Reif, D.M.; Judson, R.S.; Houck, K.A.; Casey, W.; Hsieh, J.H.; Shockley, K.R.; Ceger, P.; et al. Profiling of the Tox21 10K compound library for agonists and antagonists of the estrogen receptor alpha signaling pathway. Sci. Rep. 2014, 4, 5664. [CrossRef] [PubMed] 
340. Huang, R.; Xia, M.; Sakamuru, S.; Zhao, J.; Shahane, S.A.; Attene-Ramos, M.; Zhao, T.; Austin, C.P.; Simeonov, A. Modelling the Tox $2110 \mathrm{~K}$ chemical profiles for in vivo toxicity prediction and mechanism characterization. Nat. Commun. 2016, 7, 10425. [CrossRef] [PubMed]

341. Judson, R.S.; Magpantay, F.M.; Chickarmane, V.; Haskell, C.; Tania, N.; Taylor, J.; Xia, M.; Huang, R.; Rotroff, D.M.; Filer, D.L.; et al. Integrated Model of Chemical Perturbations of a Biological Pathway Using 18 In Vitro High-Throughput Screening Assays for the Estrogen Receptor. Toxicol. Sci. 2015, 148, 137-154. [CrossRef]

342. Mansouri, K.; Abdelaziz, A.; Rybacka, A.; Roncaglioni, A.; Tropsha, A.; Varnek, A.; Zakharov, A.; Worth, A.; Richard, A.M.; Grulke, C.M.; et al. CERAPP: Collaborative Estrogen Receptor Activity Prediction Project. Environ. Health Perspect. 2016, 124, 1023-1033. [CrossRef]

343. Mansouri, K.; Kleinstreuer, N.; Grulke, C.; Richard, A.; Shah, I.; Williams, A.; Judson, R. Virtual screening of chemicals for endocrine disrupting activity through CERAPP and CoMPARA projects. Presented at Society of Toxicology, San Antonio, TX, USA, 11-15 March 2018.

344. Ribay, K.; Kim, M.T.; Wang, W.; Pinolini, D.; Zhu, H. Predictive Modeling of Estrogen Receptor Binding Agents Using Advanced Cheminformatics Tools and Massive Public Data. Front. Environ. Sci. 2016, 4. [CrossRef]

345. Ruiz, P.; Sack, A.; Wampole, M.; Bobst, S.; Vracko, M. Integration of in silico methods and computational systems biology to explore endocrine-disrupting chemical binding with nuclear hormone receptors. Chemosphere 2017, 178, 99-109. [CrossRef]

346. Russo, D.P.; Zorn, K.M.; Clark, A.M.; Zhu, H.; Ekins, S. Comparing Multiple Machine Learning Algorithms and Metrics for Estrogen Receptor Binding Prediction. Mol. Pharm. 2018, 15, 4361-4370. [CrossRef]

347. Fernandez, M.; Ban, F.; Woo, G.; Hsing, M.; Yamazaki, T.; LeBlanc, E.; Rennie, P.S.; Welch, W.J.; Cherkasov, A. Toxic colors: The use of deep learning for predicting toxicity of compounds merely from their graphic images. J. Chem. Inf. Model. 2018, 58, 1533-1543. [CrossRef] [PubMed]

348. Gentile, F.; Agrawal, V.; Hsing, M.; Ban, F.; Norinder, U.; Gleave, M.E.; Cherkasov, A. Deep Docking-a Deep Learning Approach for Virtual Screening of Big Chemical Datasets. bioRxiv 2019. [CrossRef]

349. Makar, S.; Saha, T.; Swetha, R.; Gutti, G.; Kumar, A.; Singh, S.K. Rational approaches of drug design for the development of selective estrogen receptor modulators (SERMs), implicated in breast cancer. Bioorg. Chem. 2020, 94, 103380. [CrossRef] [PubMed]

350. Axerio-Cilies, P.; Lack, N.A.; Nayana, M.R.S.; Chan, K.H.; Yeung, A.; Leblanc, E.; Guns, E.S.T.; Rennie, P.S.; Cherkasov, A. Inhibitors of androgen receptor activation function-2 (AF2) site identified through virtual screening. J. Med. Chem. 2011, 54, 6197-6205. [CrossRef]

351. Munuganti, R.S.; Hassona, M.D.; Leblanc, E.; Frewin, K.; Singh, K.; Ma, D.; Ban, F.; Hsing, M.; Adomat, H.; Lallous, N. Identification of a potent antiandrogen that targets the BF3 site of the androgen receptor and inhibits enzalutamide-resistant prostate cancer. Chem. Biol. 2014, 21, 1476-1485. [CrossRef]

352. Munuganti, R.S.N.; Leblanc, E.; Axerio-Cilies, P.; Labriere, C.; Frewin, K.; Singh, K.; Hassona, M.D.; Lack, N.A.; Li, H.; Ban, F. Targeting the binding function 3 (BF3) site of the androgen receptor through virtual screening. 2. Development of 2-((2-phenoxyethyl) thio)-1 H-benzimidazole derivatives. J. Med. Chem. 2013, 56, 1136-1148. [CrossRef]

353. Dalal, K.; Roshan-Moniri, M.; Sharma, A.; Li, H.; Ban, F.; Hessein, M.; Hsing, M.; Singh, K.; LeBlanc, E.; Dehm, S. Selectively targeting the DNA-binding domain of the androgen receptor as a prospective therapy for prostate cancer. J. Biol. Chem. 2014, 289, 26417-26429. [CrossRef]

354. Li, H.; Ban, F.; Dalal, K.; Leblanc, E.; Frewin, K.; Ma, D.; Adomat, H.; Rennie, P.S.; Cherkasov, A. Discovery of small-molecule inhibitors selectively targeting the DNA-binding domain of the human androgen receptor. $J$. Med. Chem. 2014, 57, 6458-6467. [CrossRef]

355. Dalal, K.; Ban, F.; Li, H.; Morin, H.; Roshan-Moniri, M.; Tam, K.J.; Shepherd, A.; Sharma, A.; Peacock, J.; Carlson, M.L. Selectively targeting the dimerization interface of human androgen receptor with small-molecules to treat castration-resistant prostate cancer. Cancer Lett. 2018, 437, 35-43. [CrossRef]

356. Bienstock, R.J. Computational drug design targeting protein-protein interactions. Curr. Pharm. Des. 2012, 18, 1240-1254. [CrossRef]

357. Ferreira, L.G.; Oliva, G.; Andricopulo, A.D. Protein-protein interaction inhibitors: Advances in anticancer drug design. Expert Opin. Drug Discov. 2016, 11, 957-968. [CrossRef] 
358. Scott, D.E.; Bayly, A.R.; Abell, C.; Skidmore, J. Small molecules, big targets: Drug discovery faces the protein-protein interaction challenge. Nat. Rev. Drug Discov. 2016, 15, 533. [CrossRef] [PubMed]

359. Di Pietro, O.; Juarez-Jimenez, J.; Munoz-Torrero, D.; Laughton, C.A.; Luque, F.J. Unveiling a novel transient druggable pocket in BACE-1 through molecular simulations: Conformational analysis and binding mode of multisite inhibitors. PLOS ONE 2017, 12, e0177683. [CrossRef]

360. Eyrisch, S.; Helms, V. Transient pockets on protein surfaces involved in protein-protein interaction. J. Med. Chem. 2007, 50, 3457-3464. [CrossRef] [PubMed]

361. Kokh, D.B.; Czodrowski, P.; Rippmann, F.; Wade, R.C. Perturbation Approaches for Exploring Protein Binding Site Flexibility to Predict Transient Binding Pockets. J. Chem. Theory Comput. 2016, 12, 4100-4113. [CrossRef]

362. Hawkins, P.C.; Skillman, A.G.; Nicholls, A. Comparison of shape-matching and docking as virtual screening tools. J. Med. Chem. 2007, 50, 74-82. [CrossRef]

363. Ban, F.; Dalal, K.; LeBlanc, E.; Morin, H.; Rennie, P.S.; Cherkasov, A. Cheminformatics driven development of novel therapies for drug resistant prostate cancer. Mol. Inform. 2018, 37, 1800043. [CrossRef]

(C) 2020 by the authors. Licensee MDPI, Basel, Switzerland. This article is an open access article distributed under the terms and conditions of the Creative Commons Attribution (CC BY) license (http://creativecommons.org/licenses/by/4.0/). 